\title{
Rethinking the Supreme Court's Original Jurisdiction in State-Party Cases
}

\author{
James E. Pfander $\dagger$
}

The continuing debate about the suability of States in federal courts has failed to consider adequately the Original Jurisdiction Clause of the Constitution. The Clause granted the Supreme Court original jurisdiction over all State-party cases. In this Article, the author reclaims the Clause from obscurity and argues that the leading accounts of the Supreme Court's original jurisdiction are incomplete because they fail to see the central role that the Clause played in ensuring a judicial negative on unconstitutional state action. Through a careful historical study, the author concludes that state sovereign immunity, combined with the inadequacy of appellate jurisdiction for enforcing federal law against the states, led the framers to adopt the Original Jurisdiction Clause as a means of ensuring effective judicial enforcement of state compliance with federal law. The implication of the author's study is that the current understanding of the scope and function of the Court's original jurisdiction should be refined to extend to all cases involving state parties, both those satisfying the current diversity requirement and those involving federal law.

\section{INTRODUCTION}

In trying the legitimacy of any controverted act, we ought not to bend the constitution to our theories, but ought to adapt our theories to the constitution. ${ }^{1}$

-attributed to Henry Wheaton

Nearly two hundred years after the Supreme Court's decision in Chisholm v. Georgia ${ }^{2}$ led to the ratification of the Eleventh Amendment, ${ }^{3}$

Copyright ( 1994 California Law Review, Inc.

$\dagger$ Associate Professor of Law, University of Illinois College of Law. Special thanks to Akhil Amar, Bill Davey, William Fletcher, Dan Meltzer, Laurie Mikva, John Nowak, Bob Pushaw, and Steve Ross and to the faculty workshop at the College of Law for helpful comments; to Lee Reichert and Guy Ward for research assistance; and to the Ross and Helen Workman Fund for research support.

1. A Federalist of 1789, The Dangers of the Union (No. 3), AMERICAN (New York), July 23, 1821 , at 1 .

2. 2 U.S. (2 Dall.) 419 (1793).

3. The Eleventh Amendment provides, "The Judicial power of the United States shall not be construed to extend to any suit in law or equity, commenced or prosecuted against one of the United 
this country continues to debate the suability of states in federal courts. ${ }^{4}$ But while the debate it spawned over state immunity remains very much alive, the source of jurisdiction in Chisholm, the Court's original jurisdiction in state-party cases, ${ }^{5}$ has quietly slipped into obscurity. Today, the

States by Citizens of another State, or by Citizens or Subjects of any Foreign State." U.S. ConST. amend. XI. The Amendment became law in 1798, five years after the decision in Chisholm. For a brief and particularly well-balanced account of the ratification history, see William A. Fletcher, The Diversity Explanation of the Eleventh Amendment: A Reply to Critics, 56 U. CH. L. Rev. 1261, 1264-71 (1989). Other accounts appear in the sources cited infra notes 84, 91.

4. Supreme Court decisions push in two directions. The Court clings to a doctrine that extends state immunity beyond the text of the Eleventh Amendment. See Hans v. Louisiana, 134 U.S. 1 (1890) (dismissing federal question claim brought by citizen of the defendant state, despite the Amendmcnt's reference only to suits by citizens of another state); Principality of Monaco v. Mississippi. 292 U.S. 313 (1934) (dismissing action brought by foreign state despite the Amendment's reference only to suits brought by citizens of foreign states); Ex parte New York, 256 U.S. 490, 499-500 (1921) (dismissing action in admiralty despite the Amendment's reference only to suits in law and equity). Cf. Welch v. Texas Dep't of Highways \& Pub. Transp., 483 U.S. 468 (1987) (falling one vote short of overruling Hans). At the same time, however, the Court permits Congress to abrogate state immunity in certain circumstances. See Pennsylvania v. Union Gas Co., 491 U.S. 1, 14 (1989) (holding that Congress may abrogate state sovereign immunity under the Commerce Clause where it unequivocally expresses its intent to do so); Atascadero State Hosp. v. Scanlon, 473 U.S. 234, 242 (1985) (holding that Congress may abrogate state sovereign immunity under Section 5 of the Fourteenth Amendment where it speaks with the requisite clarity).

Similar differences divide the legal academy. Some observers agree with the Court's apparently atextual extension of state immunity. See William P. Marshall, The Diversity Theory of the Eleventh Amendment: A Critical Evaluation, 102 HARv. L. Rev. 1372 (1989) (arguing that critiques of Hans do not justify abandonment of its result). Others explain the Amendment as a limited repealer of diversity jurisdiction and call for change in current doctrine. The scholars who support a diversity explanation argue, in effect, that the Amendment restricts federal jurisdiction only in those diverse-party controversies that fail to implicate federal law and leaves intact other sources of federal jurisdiction, including those supplied by the federal question and admiralty grants. See infra note 91 . Such a reading of the Amendment would overturn Hans and Ex parte New York. Still others proffer a literal reading of the Eleventh Amendment that would also require doctrinal patchwork. They argue that the Eleventh Amendment curtails all federal judicial power over suits brought against the states by disfavored plaintiffs, including suits that rest on federal question and admiralty sources of jurisdiction. See Lawrence C. Marshall, Fighting the Words of the Eleventh Amendment, 102 Harv. L. Rev. 1342 (1989); Calvin R. Massey, State Sovereignty and the Tenth and Eleventh Amendments, 56 U. CH1. L. Rev. 61 (1989). To such literal theorists, Hans was wrongly decided not because it reads the Eleventh Amendment to deprive the federal courts of jurisdiction over federal question claims but because it applies the Amendment to a suit brought by a citizen of the defendant state. For a summary of the essentially friendly debate between literalists and diversity theorists, see Fletcher, supra note 3, at 127689.

5. Article III declares that "[in all Cases] in which a State shall be a Party, the supreme Court shall have original Jurisdiction." U.S. Const. art. III, $\S 2$. The Judiciary Code provides that

(a) The Supreme Court shall have original and exclusive jurisdiction of all controversies

between two or more States.

(b) The Supreme Court shall have original but not exclusive jurisdiction of:

(2) All controversies between the United States and a State;

(3) All actions or proceedings by a State against the citizens of another State or against aliens.

28 U.S.C. $\S 1251$ (1988). As currently codified, therefore, the Court's original jurisdiction focuses on the identity of the litigants. It defines two favored litigants, the states themselves and the United Statcs, and permits them to initiate actions on the Court's original docket. Other prospective plaintiffs, including citizens of the United States, aliens, and foreign nations, lack any statutory authority to invoke the Court's original jurisdiction. No grant of federal question jurisdiction appears in the statute. 
Court's original docket consists primarily of disputes between states over the location of interstate boundaries ${ }^{6}$ and the allocation of interstate waters. ${ }^{7}$ Occasionally, cases of more than passing interest will appear. ${ }^{8}$ But, as Professor Gunther has explained, the Court's original jurisdiction is rarely invoked and is "even more rarely the source of sigmificant constitutional interpretations." It plays no substantial role in current debates over the scope of state sovereign immunity and the breadth of the Eleventh Amendment. ${ }^{10}$

6. For recent examples of the invocation of the Court's original jurisdiction to resolve border disputes, see Louisiana v. Mississippi, 466 U.S. 96 (1984); California v. Nevada, 447 U.S. 125 (1980); Ohio v. Kentucky, 444 U.S. 335 (1980); California v. Arizona, 440 U.S. 59 (1979). Such jurisdiction was apparently first invoked in New Jersey v. New York, 30 U.S. (5 Pet.) 284 (1831) and was first definitively confirmed in Rhode Island v. Massachusetts, 37 U.S. (12 Pet.) 657 (1838).

7. For recent examples, see Colorado v. New Mexico, 459 U.S. 176 (1982), dismissed, 467 U.S. 310 (1984); Vermont v. New York, 417 U.S. 270 (1974). The leading case is Kansas v. Colorado, 185 U.S. 125 (1902).

Other categories of original jurisdiction cases include disputes between states over burdens on interstate commcrce, see, e.g., Wyoming v. Oklahoma, 112 S. Ct. 789 (1992); Pennsylvania v. West Virginia, 262 U.S. 553 (1923), and over the interpretation of interstate compacts, see Texas v. Netv Mexico, 462 U.S. 554 (1983), amended, 112 S. Ct. 291 (1991); Nebraska v. Iowa, 406 U.S. 117 (1972). See generally Felix Frankfurter \& James M. Landis, The Compact Clause of the Constitution-A Study in Interstate Adjustments, 34 YALE L.J. 685 (1925) (discussing constitutional problems created by state compacts as adjudicated by the Supreme Court); David E. Engdahl, Construction of Interstate Compacts: A Questionable Federal Question, 51 VA. L. Rev. 987 (1965) (criticizing the law of the Union doctrine, on which certiorari review by the Supreme Court relies).

In addition to these claims, the Court hears claims on its original docket in the nature of interpleaders between states that compete for rights of escheat, see Pennsylvaria v. New York, 407 U.S. 206 (1972), superseded by statute as stated in Delaware v. New York, 113 S. Ct. 1550 (1993); Texas v. New Jersey, 379 U.S. 674 (1965), and for the right to impose tax liability on the estates of decedents who lived in more than one state, see California v. Texas, 457 U.S. 164 (1982); Texas v. Florida, 306 U.S. 398 (1939).

8. See South Carolina v. Baker, 485 U.S. 505 (1988) (upholding denial of exemption from federal income tax for interest paid on local government bearer bonds); South Carolina v. Regan, 465 U.S. 367 (1984) (allowing challenge to Internal Revenue Code provision withholding tax exemption from state bearer bonds); Maryland v. Louisiana, 451 U.S. 725 (1981) (challenging Louisiana "first-use tax" on natural gas); Oregon v. Mitchell, 400 U.S. 112 (1970) (considering constitutional challenge to Voting Rights Act Amendments of 1970); South Carolina v. Katzenbach, 383 U.S. 301 (1966) (considering constitutional challenge to provisions of the Voting Rights Act of 1965).

9. Gerald Gunther, Constitutional Law 52 (12th ed. 1991).

10. To be sure, the current edition of Hart and Wechsler's encyclopedic federal courts casebook devotes an early chapter to the Court's original docket. See Paul M. Bator et AL., Hart \& Wechsler's The Federal Courts aNd tHe Federal System 295-361 (3d ed. 1988) [hereinafter Hart \& Wechsler]; see also 17 Charles A. Wright et al., Federal Practice and Procedure $\$ \S 4042-54$ (2d ed. 1988) [hereinafter WRIGHT \& Miller]. Such treatment has increasingly become the exception, however. See, e.g., Peter W. Low \& John C. Jefrries, Jr., Federal Courts and the Law of Federal-State Relations (2d ed. 1989) (omitting original jurisdiction from coverage); Martin H. Redish, Federal Jurisdiction: Tensions in the Allocation of Judicial Power 25 (2d ed. 1990) (omitting original jurisdiction from coverage but noting its self-executing character). Thus, aside from a recent piece by Akhil Reed Amar, Marbury, Section 13, and the Original Jurisdiction of the Supreme Court, 56 U. CHI. L. REv. 443 (1989), leading law reviews have published little of interest in the area since Stanford colleeted a comprehensive list of citations to the Court's original decisions. See Note, The Original Jurisdiction of the United States Supreme Court, 11 STAN. L. REv. 665 (1959). For a description of recent cases on the Court's original docket, updating the Stanford note, see Vincent $L$. McKusick, Discretionary Gatekeeping: The Supreme Court's Management of lts Original Docket Since 
In this Article, I propose to reclaim the Court's original jurisdiction from its relative obscurity and relocate it at the center of the framers' plan to secure the effective enforcement of federal law against the states. That plan, which sought to create a judicial negative on unlawful state action, contained at least five related elements. First, the framers fashioned a series of specific limitations on the powers of the states. ${ }^{11}$ Second; the framers authorized the federal courts to exercise jurisdiction over all "cases" that implicated such constitutional (and other federal) limitations. Third, the framers declared such federal limits to be the supreme law of the land, binding on the states notwithstanding contrary provisions of state law. Fourth, the framers conferred appellate jurisdiction on the Court in many of the "cases" that implicate federal law. The fifth element of the framers' plan, I suggest here, was Article III's declaration that the Court shall have original jurisdiction in all state-party "cases."

Two factors made such a mandatory and self-executing ${ }^{12}$ grant of original jurisdiction absolutely essential to the enforcement of federal law

1961, 45 ME. L. Rev. 185 (1993). For other discussions, see William S. Bames, Suits Between States in the Supreme Court, 7 VAND. L. Rev. 494 (1954) (discussing original jurisdiction in the United States as a prerequisite for plans to expand business of the World Court in the future); Paul F. Good, Judicial Determination of Interstate Disputes, 26 NeB. L. Rev. 1 (1946) (examining Supreme Court original jurisdiction in interstate disputes); W.J. Wagner, Original Jurisdiction of National Supreme Courts, 33 ST. JoHN's L. REv. 217 (1959) (discussing original jurisdiction of supreme courts in different countries).

11. A word about methodology. I am not a committed originalist but, like most other scholars, I believe that the text and history of Article III offer important insights into the proper interpretation of judicial power today. I occasionally speak in this Article of the framers' intent, but I recognize that such intent is something of an abstraction.

12. The Court and commentators alike have, tended to agree that the mandatory character of the Original Jurisdiction Clause imposes some limits on the power of Congress to restrict the scope of the Court's original jurisdiction. The Court held in Chisholm v. Georgia, 2 U.S. (2 Dall.) 419, 451, 463-64, 467, 479 (1793) (Justices Blair, Wilson, Cushing, and Jay, respectively) that the clause was selfexecuting: the failure of Congress to fashion a mode of executing judgments against the statcs was no bar to the assertion of jurisdiction. See also New Jersey v. New York, 30 U.S. (5 Pet.) 284, 287 (1831) (holding that the Court could exercise original jurisdiction in suits against a state, even though Congress had not prescribed how such suits should proceed). More recent decisions suggest that the clause is not only self-executing but mandatory - that Congress lacks power to deprive the Court of its original cognizance over the speeified state-party disputes. See California v. Arizona, 440 U.S. 59, 61, 65 (1979); United States v. Texas, 143 U.S. 621, 644 (1892). Scholars have generally accepted the proposition that the clause mandates the assertion of original jurisdiction. See Henry M. Hart, Jr., The Power of Congress To Limit the Jurisdiction of Federal Courts: An Exercise in Dialectic, 66 HARv. L. REv. 1362, 1372-73 (1953) (arguing that a civil litigant is not guaranteed a hearing in a fcderal constitutional court if Congress provides some altemative procedure, except when the Court excrcises original jurisdiction); Martin H. Redish, Congressional Power to Regulate Supreme Court Appellate Jurisdiction Under the Exceptions Clause: An Internal and External Examination, 27 ViLL. L. REv. 900, $901 \mathrm{n} .7$ (1981-82) (contrasting the Court's appellate jurisdiction, which Congress may regulate, with its original jurisdiction, which is insulated from regulation); $c f$. HART \& WECHSLER, supra note 10, at 296 97 (generally agreeing that Article 111 mandates the existence of original jurisdiction but criticizing decisions that read the mandate as a restriction on Congress' power to injpose reniedial and proccdural limits on suits brought within that jurisdiction). But see Akhil R. Amar, A Neo-Federalist View of Article III: Separating the Two Tiers of Federal Jurisdiction, 65 B.U. L. Rev. 205, 254 n.160 (1985) (arguing that Congress may abolish all federal jurisdiction, including that of the Supreme Court, over cases in which a state is a party); Amar, supra note 10, at 478-88 (expanding his carlier arguncent that 
against the states in their sovereign or collective capacity. First, states enjoyed two sources of immunity from suit under the Articles of Confederation. The niore familiar source of immunity, and the one to which Justice Iredell devoted his dissenting opinion in Chisholm, stemmed from the failure of the common law to develop a writ running against the King. This "common law" immunity essentially barred individuals from bringing a suit against the states in their own courts; it differs from a second source of immunity that I will label "law-of-nations" immunity. Law-ofnations immunity, an attribute of state sovereignty under the Articles, established an independent barrier to suits against states in the courts of other sovereigns. Without a grant of jurisdiction clearly authorizing the federal courts to hear claims against the states, the framers may have feared that states would successfully invoke law-of-nations sovereign immunity as a bar to suit in the courts of the federal sovereign.

The second factor necessitating a mandatory grant of original jurisdiction in state-party cases was the inability of the federal courts adequately to police state comphance with federal law througl the exercise of purely appellate jurisdiction. The Madisonian compromise, which followed the Philadelphia convention's rejection of a proposal to mandate inferior federal courts, empowered but did not require Congress to create inferior courts. The compromise thus confronted the framers with the prospect that Congress would iniplement Article III by leaving the adjudication of all matters of federal cognizance to the state courts in the first instance. The framers responded to this prospect in part with Article III, Section 2's famous declaration that the Court shall have appellate jurisdiction in "all the other Cases before mentioned." This grant of jurisdiction provided for Supreme Court review of federal question cases that originated before state tribunals.

The grant of appellate jurisdiction would not have been sufficient to ensure state court compliance with federal law, however. A decision by Congress to implenient Article III by leaving the original litigation of federal claims to the state courts would have presented a real threat to the enforcement of federal law against the states. The established common law and law-of-nations immunities would have immunized the states from suits by individuals, both at home and in the courts of other states. Such state court invocations of established immunities would apparently have evaded Supreme Court appellate review, thereby creating a remedial gap. One

Congress may eliminate all federal jurisdiction, including Supreme Court original jurisdiction, over state-party cases).

Despite this relatively general agreement among scholars about the mandatory character of the Court's original jurisdiction, Congress has always enacted statutes that purport affirmatively to confer original jurisdiction on the Court. For the text of the first such statutory provision, section 13 of the Judiciary Act of 1789, see infra text accompanying note 351; for the text of the current version, see supra note 5 ; and for suggested modifications in the current text to better reflect the proper scope of the constitutional grant, see infra text accompanying note 424 . 
solution to the remedial gap would have been to require the states to entertain actions against themselves. The far simpler solution was to provide the only constitutionally mandated federal court-the Supreme Court-with original jurisdiction over claims against the states.

My account of the relationship between the Original Jurisdiction Clause and the dual doctrines of state sovereign immunity sheds new light on the debate over the framers' understanding of state suability. The framers appear consciously to have chosen to subject the states to suit in federal courts, thus vitiating the states' law-of-nations immunity. Yet the framers did not necessarily intend the grant of jurisdiction to abrogate the states' common law immunity in all disputes to which the original jurisdiction extends. As the dissenting opinion of Justice Iredell in Chisholm attests, common law limitations on the suability of states may well have been understood to have survived a simple grant of jurisdiction to the federal courts. In a good many such disputes, and particularly in actions in which individuals sought to enforce non-federal rights, no source of supreme federal law would have justified the federal courts in imposing liability on the states.

This understanding of the relationship between the Court's original jurisdiction and the enforcement of federal law against the states calls for a re-examination of the function of the Court's original jurisdiction in stateparty cases. I begin this process by reviewing and criticizing as incomplete the two leading explanations of the Court's original jurisdiction: (1) the "dignified tribunal" explanation, which emphasizes the framers' desire to secure the Supreme Court as a "dignified" original tribunal for the assertion of claims involving state parties; (2) Professor Akhil Amar's geographic explanation, which claims that the grant of original jurisdiction implements twin policies of geographic convenience and impartiality. I suggest that an explanation of the grant that focuses on the framers' intent to ensure judicial enforcement of states' compliance with federal law offers a more satisfying account of its function.

My thesis also requires reconsideration of the traditional account of the scope of the Court's original jurisdiction. The Court and most scholars have long assumed that the Court's original jurisdiction extends only to those disputes that Article III's "jurisdictional menu"13 defines as stateparty "controversies." On such a reading, the Court lacks federal question and admiralty jurisdiction over claims involving the states unless the claims happen to arise between properly aligned, diverse parties. Such a reading is difficult to sustain in light of the text of the clause, which refers to stateparty "cases" and thus appears to encompass all the "cases" that Article III defines as arising under federal law. I contend that we should read the

13. See U.S. ConST. art. III, $\S 2$, cl. 1. I borrow Professor Amar's useful term to describe the list of proceedings to which Article III, Section 2 extends the judicial power. For the text of Article III, Section 2, see infra text accompanying note 175 . 
clause to encompass all state-party cases, including federal question and admiralty cases, and not simply the diverse-party controversies. Such a reading better reflects the framers' concern with the enforcement of federal law against the states.

One finds much in the ratification debates, the subject of Part IV of this Article, that confirms the framers' understanding of the relationship between original jurisdiction and state sovereign immunity. Such leading architects of Article III as Alexander Hamilton, James Madison, James Wilson, and Ednund Randolph offered accounts of state suability that closely resemble that developed here. Madison and Randolph (expressly) and Hamilton (implicitly) identified the Court's original jurisdiction in state-party cases as an important source of coercive judicial power over the states; Hamilton and Randolph both linked the function of the clause to the abrogation of states' law-of-nations immunity; Hamilton and Madison both seemingly affirmed the states' retention of sone common law immunity by denying that any surrender of immunity would extend to non-federal clainis brought by individuals.

Much the same understanding emerges fron a close reading of the Chisholm opinions. Both Randolph's argument for the plaintiff and the opinions of the Justices, on the whole, appear to regard the Court's jurisdiction over claims against the states as well established. ${ }^{14}$ Equally clear, according to Randolph, was the power of the federal courts to fashion a damages remedy in favor of individual suitors in actions that implicated federal law. More doubtful was the Court's power to impose liability on the states in non-federal disputes. Taken together, the argument and opinions recognize that the grant of original jurisdiction effected a broad-based waiver of the states' law-of-nations immunity from suit in federal court. The drafters of the Eleventh Amendment may have sought to restore such an immunity, at least in part, but at the time of the drafting of the Constitution, the framers' intent was clear: the Original Jurisdiction Clause was meant to abrogate the states' law-of-nations immunity.

My claim that the grant of original jurisdiction constitutionally establishes a federal judicial role in assuring state compliance with federal law proceeds in five sections. Part I offers a review and critique of the leading accounts of the function and scope of the Court's original jurisdiction. Part II focuses on the two sources of state sovereign immunity, the law of nations and the common law, that confronted the framers of Article III. The Part criticizes the two dominant accounts of sovereign immunity, the "profound shock" theory and the revisionist theory, and instead identifies the central role that the Original Jurisdiction Clause played in ensuring a judicial negative on unconstitutional state action. Part III offers a textual, structural, and historical argument for an interpretation of the Original

14. See infra notes $391-99$ and accompanying text. 
Jurisdiction Clause that encompasses all state-party cases including both federal question and diverse-party heads of jurisdiction. Part IV examines the drafting history and ratification debates, both of which reveal strong though not entirely unambiguous support for this Article's theses.

Finally, in Part V, I consider the two major implications of my study. First, I find significant textual, structural, and historical evidence of the framers' desire to effect a waiver of the states' law-of-nations immunity from suit in federal court. Although the bottom line is confused somewhat by ambiguities in the degree to which the Constitution also vitiates the states' common law immunity, the grant of original jurisdiction offers relatively clear evidence that the framers sought to overcome states' immunity at least to the extent necessary to effectuate federal law. While I do not explore at great length the implications of these conclusions for the original understanding of the Eleventh Amendment, I do agree with revisionists who argue that the framers of the Constitution meant to subject the states to suit in federal court. On that point, there is no ambiguity.

Second, I argue that we should refine the current understanding of the scope and function of the Court's original jurisdiction. Rather than offering the states a dignified tribunal, the Court's original docket was designed to ensure the effective enforcement of federal law against the states. Therefore, the Court's original jurisdiction was meant to extend to all cases involving state-parties, including both those that arise under federal law and those that satisfy the current party-alignment, diversity test. I tentatively explore some ways in which Congress and the Court might reconfigure the original docket and reallocate jurisdiction to the lower federal courts in light of these findings.

I

The InCOMPleteness of LeAding ACCOUNTS of the Court's ORIGINAL JURISDICTION

The Supreme Court's original jurisprudence in state-party cases bears the distinctive, and somewhat messy, nuark of common law evolution. Early and poorly thought out dicta have become bedrock limits on the scope of the Court's original jurisdiction; differing conceptions of its purpose have coexisted for years; and the clear text of the Constitution has been submerged under the weight of two hundred years of precedent. In this Section, I explore the dominant accounts of the function of the Court's original docket and consider the exclusion of federal question cases from the leading interpretations of the scope of the Court's original jurisdiction.

\section{A. The "Purposes" of Original Jurisdiction: The "Dignified Tribunal" Account}

The first account of the purpose of the Court's original docket builds on the fact that the Court's original jurisdiction extends to only two kinds of 
cases, those involving the states and those involving envoys of foreign nations. According to this account, the framers vested the Court with original jurisdiction in state-party cases in order to "match [ ] the dignity of the parties to the status of the court."15 One can trace this account, which I will call the "dignified tribunal" theory, to The Federalist No. 81, where Hamilton asserted that "[i]n cases in which a state might happen to be a party, it would ill suit its dignity to be turned over to an inferior tribunal."16

The Court has generally invoked the dignified tribunal argument in connection with actions brought by the states as plaintiffs. In Ames v. Kansas, ${ }^{17}$ an action initiated by the State of Kansas in its own courts and removed to federal court, the Court explained that the "evident" purpose of the grant of original jurisdiction was to "open and keep open the highest court of the nation for the determination, in the first instance, of suits involving a State or a diplomatic or commercial representative of a foreign government." ${ }^{18}$ Justice O'Connor recently built upon this conception of the grant as a favor to state plaintiffs, arguing in her concurring opinion in South Carolina v. Regan ${ }^{19}$ that the framers' concern for the role of the sovereign states in the federal system led thein to secure a federal docket for the assertion of claims by the states. ${ }^{20}$

As elaborated by Justice O'Connor in her Regan opmion, the dignified tribunal argument relies heavily on the seemingly inandatory declaration that the Court "shall have" original jurisdiction in state-party cases. As Justice O'Connor correctly notes, the Court has long regarded its original jurisdiction as mandatory and self-executing-a view said to deprive Congress of power to restrict the jurisdiction conferred by the Constitution, and said to enable the Court to exercise jurisdiction even in the absence of an affirmative grant of jurisdiction by Congress. ${ }^{21}$ Justice $\mathrm{O}^{\prime}$ Connor also correctly observes that Marbury v. Madison ${ }^{22}$ deprives Congress of power to broaden the Court's original jurisdiction. ${ }^{23}$ Both of these widely accepted limits on the power of Congress support the claim that Article III secures the Court's original docket as a dignified tribunal for state parties.

15. California v. Arizona, 440 U.S. 59, 65-66 (1979); see also Louisiana v. Texas, 176 U.S. 1,15 (1900); Ames v. Kansas, 111 U.S. 449, 464 (1884); HART \& WECHSLER, supra note 10, at 295-96; Note, The Original Jurisdiction of the United States Supreme Court, supra note 10, at 665.

16. The Federalist No. 81, at 548 (Alexander Hamilton) (Jacob E. Cooke ed., 1961). For a more complete discussion of Hamilton's understanding, see infra notes 300-16 and accompanying text. One also finds traces of the dignified tribunal argument in the cases. See, e.g., Louisiana v. Texas, 176 U.S. $1,15(1900)$ (characterizing the Court's original jurisdiction as "of so delicate and grave a character that it was not contemplated that it would be exercised save when the necessity was absolute").

17. 111 U.S. 449 (1884).

18. Id. at 464 .

19. 465 U.S. 367 (1984).

20. Id. at 396-97 (O'Connor, J., concurring).

21. Id. at 397 (O'Connor, J., concurring); see also supra note 12.

22. 5 U.S. (1 Cranch) 137 (1803).

23. Regan, 465 U.S. at 397. 
Yet the dignified tribunal argument remains incomplete as a theory of the purpose and scope of the Court's original jurisdiction. To begin with, Article III's jurisdictional menu extends the judicial power of the federal courts to "controversies" involving the United States and those involving foreign nations. Both parties enjoy the same sovereign status that the dignified tribunal argument recognizes in states and in the envoys of foreign nations. Article III, however, does not extend the Court's original jurisdiction to cases involving the United States and foreign nations, instead consigning the original determination of disputes involving them to the state and lower federal courts. The dignified tribunal account cannot explain the omission of such sovereigns from the Original Jurisdiction Clause.

Nor can the dignified tribunal account explain why some cases concededly within the Court's original jurisdiction receive their original determination in state and lower federal courts. The dignified tribunal argument appears to claim a special role for the Supreme Court, one that matches the dignity of the parties to the dignity of the tribunal and forecloses resolution of such claims by what Hamilton termed "inferior tribunal[s]." Such a suggestion of exclusivity, however, conflicts with such settled doctrines of original jurisprudence as the power of Congress to vest lower courts with concurrent jurisdiction and the Court's discretion to decline to exercise its original jurisdiction.

Consider first the well-established doctrine that Congress may assign matters otherwise within the Court's original jurisdiction to the lower federal courts. ${ }^{24}$ Congress has routinely exercised this power since adopting the Judiciary Act of $1789 . .^{25}$ Section 13 of the Act conferred exclusive original jurisdiction on the Court in actions brought against ambassadors and conferred original, but nonexclusive, jurisdiction over actions brought by ambassadors. ${ }^{26}$ The Act also explicitly conferred power on the lower federal courts to hear actions against consuls ${ }^{27}$-representatives of foreign countries who did not enjoy full-blown ambassadorial immunity. ${ }^{28}$ With respect to state-party cases, the Act followed a similar pattern, vesting the Court with exclusive cognizance of some state-party cases, but permitting

24. In a later Section, I argue that the framers expected Congress to exercise this authority and made their expectations express in a clause that was ultimately deleted from Article III on grounds of redundancy. See infra notes $260-62$ and accompanying text.

25. Ch. 20, 1 Stat. 73.

26. The Act's failure to confer exclusive jurisdiction over actions brought by ambassadors recognizes that claims by ambassadors did not implicate the doctrine of ambassadorial immunity and might more conveniently be heard in lower courts. Furthermore, section 11 of the Act authorizcs the circuit courts to exercise concurrent jurisdiction with the state courts over actions brought by alicns-a category broad enough to encompass civil claims by ambassadors. The Act thus contemplates lower federal court and state court proceedings in cases affecting ambassadors.

27. Section 9 of the Act authorizes the district courts to exercise "jurisdiction exclusively of the courts of the several States, of all suits against consuls or vice-consuls."

28. See $1 \mathrm{KENT}$, infra note 41 , at 53 . 
the state courts to exercise concurrent jurisdiction over disputes between states and diverse citizens and aliens. ${ }^{29}$

For their part, the Justices have consistently upheld the power of Congress to grant the lower federal courts concurrent jurisdiction over matters within the Court's original jurisdiction. They did so first in an opinion by James Wilson, riding circuit, ${ }^{30}$ and later in opinions by the full Court in Börs v. Preston ${ }^{31}$ and Ames v. Kansas. ${ }^{32}$ Even nuore dramatic, the Court's decision in Nevada v. Hall ${ }^{33}$ upholds the power of the state courts themselves to entertain coercive clainis against sibling states, thereby rejecting the argunient that the federal courts enjoy exclusive authority over state defendants under the terms of the Original Jurisdiction Clause. ${ }^{34}$ As Chief Justice Rehnquist recently observed, congressional authority to make the Court's original jurisdiction exclusive in some cases and concurrent in others "has existed since the Judiciary Act of 1789, and has never been questioned by this Court." 35 Such an unquestioned tradition undermines any claim that the Original Jurisdiction Clause frees the states from the indignity of litigation in the lower courts.

The Court also frequently exercises its discretion to refrain from liearing claims that come within its original jurisdiction, notwithstanding argu-

29. Section 13 gives the Court original and exclusive jurisdiction over "all controversies of a civil nature, where a state is a party, except ... . between a state and citizens of other states, or aliens, in which latter case it shall have original but not exclusive jurisdiction." Since the remainder of the Act fails to vest the lower federal courts with any power over state-party cases, the drafters must have contemplated that at least some such suits (presumably those initiated by the states themselves) would go forward in the state courts. See infra note 41 . The law of nations barred only suits in state court against another sovereign; it did not preclude the states from initiating actions against individuals in other state courts. See supra note 41; see also Governor of Georgia v. Madrazo, 26 U.S. (1 Pet.) 110, 129 (1828) (Johnson, J., dissenting) (arguing that states may bring actions as plaintiffs in any court of competent jurisdiction, notwithstanding the Constitution and Judiciary Act's grant of original jurisdiction to the Supreme Court).

30. See United States v. Ravara, 2 U.S. (2 Dall.) 297 (C.C.D. Pa. 1793). Ravara, a consul from Genoa, was charged with extortion in violation of the criminal laws of the United States. He moved to quash the indictment on the ground that the Constitution gave the Supreme Court original and therefore exclusive cognizance of such proceedings. The Judiciary Act was said to contradict this constitutional mandate in two of its sections-in section 13 by permitting the lower courts to take cognizance of matters affecting consuls, and in section 11 by giving the lower federal courts exclusive jurisdiction over criminal trials. The latter provision was said unconstitutionally to divest the Supreme Court of its original authority over consular crimes.

Justice Wilson's opinion for the circuit court refused to quash the indictment and declined to reach the question whether section 11 divested the Court of some portion of its original jurisdiction. Rather, Wilson based his opinion on the ground that Congress was free to vest the lower courts with concurrent jurisdiction of matters within the scope of the original grant. By treating the lower court as exercising a concurrent jurisdiction, Wilson's opinion left open the question whether Congress could constitutionally divest the Court of power over consular crimes.
31. 111 U.S. 252 (1884).
32. 111 U.S. 449 (1884).
33. 440 U.S. 410,420 (1979).
34. Id. at 420-21.
35. Mississippi v. Louisiana, 113 S. Ct. 549, 553 n.1 (1992). 
ments that it has a duty to provide a forum to dignified sovereign states. ${ }^{36}$ In Ohio v. Wyandotte Chemicals Corp. ${ }^{37}$ Justice Harlan offers the leading statement of the Court's discretionary power, arguing that the Court's scarce resources would be better devoted to the resolution of federal questions than to the original resolution of claims arising under state law. ${ }^{38}$ The Court has insisted on its discretionary authority in the face of relatively persuasive dignified tribunal arguments. In Louisiana v. Cummins, ${ }^{39}$ for example, counsel vainly argued that such a discretionary denial of jurisdiction "completely defeats the purpose of the judiciary article ... . and places sovereign states in a worse position than private citizens and creatures of states-i.e., corporations-who can in similar circumstances invoke the diversity of citizenship jurisdiction." 40 Therefore, the Original Jurisdiction Clause cannot be explained solely in reference to providing a dignified tribunal for the benefit of the plaintiff states.

Although it does not support a claim as to the exclusive or non-discretionary character of the Court's original jurisdiction, the dignified tribunal account correctly conceives of the Court's original docket as providing a tribunal for the states as defendants. The prevailing doctrines of state sovereign immunity before the framing of the Constitution had barred individuals from suing states in state courts. In contrast, however, states were generally free under the law prevailing under the Articles of Confederation

36. The Court first exercised this discretion in Massachusetts v. Missouri, 308 U.S. 1, 18-19 (1939) (holding that the interest of Massachusetts in collecting state taxes from Missouri citizens was too insubstantial to justify an assertion of original jurisdiction where there was another proper and adequate remedy available). Since then, the doctrine has been expanded to apply to suits brought by the United States against a state, see United States v. Nevada, 412 U.S. 534, 538 (1973) ("We seck to exercise our original jurisdiction sparingly and are particularly reluctant to take jurisdiction of a suit where the plaintiff has another adequate forum in which to settle his claim."), and to suits betwecn (wo or more states, see Arizona v. New Mexico, 425 U.S. 794 (1976). The last expansion has proven controversial, in light of the fact that title 28 provides the Court exclusive jurisdiction ovcr such interstate disputes. See id. at 798-99 (Stevens, J., concurring) (cautioning that the Court's preccdents do not adequately support an order denying a state leave to file a complaint against another state when no other forum is available); Louisiana v. Mississippi, 488 U.S. 990 (1988) (White, J., dissenting) (dissenting from Court's discretionary denial of plaintiff's motion for leave to file complaint in boundary dispute within the Court's exclusive jurisdiction), rev'd in part, $113 \mathrm{~S}$. Ct. 549 (1992). But see David L. Shapiro, Jurisdiction and Discretion, 60 N.Y.U. L. Rev. 543, 545 (1985) (concluding that federal courts' discretion not to hear cases within their jurisdiction "contributc[s] to the easing of interbranch and intergovernmental tensions" and protects federal courts from being overburdened).

The Court has long required parties who seek to invoke its original jurisdiction to file a petition for leave to do so. The Court typically exercises its discretion at the threshold of the action, but the question of jurisdiction remains open throughout the litigation of the case. For a summary of the relevant procedural nules, see Robert L. Stern et. al., Supreme Court Practice $\S \S 10.7-.13$ (6th ed. 1986); 17 WRIGHT \& MiLLER, supra note $10, \S 4054$.

37. 401 U.S. 493 (1971).

38. Id. at 497-99. Harlan emphasized Ohio's failure to present any pressing issue of federal law as the basis for the Court's decision to refrain from exercising its jurisdiction. Id. at 504.

39. 314 U.S. 580 (1941).

40. Brief of Counsel in Support of Petition for Rehearing, cited in HART \& WECHSLER, supra note 10 , at 341 . 
to institute suits as plaintiffs in the courts of sibling states. ${ }^{41}$ The innovative feature of Article III's grant of original jurisdiction over state-party cases was its provision for suit against state defendants. ${ }^{42}$ Such involuntary appearances as defendants in federal court would have more clearly imphcated the states' dignity interests than their voluntary invocation of federal jurisdiction as plaintiffs. This Article suggests that we should refine the dignified tribunal argument to emphasize the Original Jurisdiction Clause's distinctive provision for suits against state defendants.

41. On the prevailing conception of state sovereign immunity at the time of the framing of the Constitution, emphasizing the law-of-nations barrier to the prosecution of suits against state defendants in the courts of other sovereigns, see infra notes 84-131 and aecompanying text. A variety of evidence supports the view that the framers believed that state plaintiffs, im comparison, could freely prosecute claims against individual citizens in the courts of other sovereigns. To begin with, under international law prevailing at the time of the framing, foreign nations were free to file suit against Americans in the courts of the United States. See 1 JAMES Kent, Commentaries on AMERICAN LAw 319-20 \& nn.(e) \& 1 (O.W. Holmes, Jr., ed., 12th ed. 1873). On such a reading of the law of nations, the immumity that state defendants enjoyed under the Articles of Confederation would not have barred them from bringing suit as plaintiffs in their own or other state courts.

Couple the lessons of the law of nations with evidence from section 13 of the Judiciary Act of 1789 , ch. 20,1 Stat. 73,80 . Section 13 makes the Court's original jurisdiction in certain state-party matters exclusive but refrains from doing so in controversies between a state and diverse citizens and aliens. See infra note 351 and accompanying text (setting forth text of section 13). Such a deliberate declaration of nonexclusivity must have been designed to preserve state court competence to hear actions brought by state plaintiffs, inasmuch as the lower federal courts had been given no authority to hear such disputes. See Ames v. Kansas, 111 U.S. 449, 463-65 (1884) (adopting this interpretation of the declaration of non-exclusivity, albeit in dicta); see also 4 THE Documentary History of THE Supreme Court of the United States, 1789-1800: Organizing the Federal Judictary 130 (Maeva Marcus ed., 1992) [hereinafter Documentary History of THE Supreme CourT] (reprinting 1790 report to Congress by Attomey General Edmund Randolph) (argning that the Court's original jurisdiction over claims brought against the states was not inconsistent with the right of the states separately, and the United States, to resort to state courts as plaintiffs).

Although I have failed to uncover any decisional law from the ratification era that definitively affirms the right of states to pursue actions as plaintiffs on the dockets of other sovereigns, postratification decisions squarely hold that states may bring such suits. In Delafield v. Illinois, 2 Hill 159 (N.Y. 1841), the New York Court of Errors permitted the State of Illinois to pursue claims in New York trial courts. As the Delafield court explained:

1 cannot entertain a doubt that one of the states of this union may sue in its political or corporate capacity. In that capacity it may contract and acquire rights; and there can be no reason why, like every other legal being, it should not be allowed to sue for the redress of wrongs. It is matter of every day observation that such suits have been brought and maintained; and I am not aware that any one has ever thought before of making a question about it. I see no difference whether the state sues in its own courts or in those of another jurisdiction.

Id. at 162.

42. That state fora were already available for state-plaintiff cases suggests that addressing the states' interests as plaintiffs was not among the core purposes of the original jurisdiction grant, though the grant permits states to bring actions as plaintiffs. The Delafield court observed:

Prior to the adoption of the federal constitution a state might sue, but could not be sued; and there may be some reason for supposing that states were inentioned in the article relating to the judicial power of the U.S., for the purpose of providing a forum in which they might be impleaded as defendants....

$I d$. at 162-63. In sum, the court suggests that the distinctive feature of the Original Jurisdiction Clause lies in its provision for suits against state defendants. 


\section{B. Professor Amar's Geographic Account}

Professor Akhil Amar has recently offered an alternative account that focuses less on the dignity of the Court's original docket than on the Court's geographic convenience and impartiality. ${ }^{43}$ Amar contends that geography explains why the framers extended the Court's original jurisdiction to claims involving state parties and foreign envoys. Both such parties would enjoy relatively convenient access to an original docket at the nation's capital. States were to be represented there by their senators; foreign ambassadors would typically reside in the capital in furtherance of their diplomatic mission. Amar also observes that Marbury's restriction on congressional power to broaden the Court's original docket makes sense in geographic terms because it bars Congress from imposing on other parties the burden and expense of litigation at the center. ${ }^{44}$

In addition to convenient access, Amar sees the Court's original docket as offering state parties a geographically neutral venue for the resolution of their disputes. ${ }^{45}$ Historically, it has proven to offer such a venue. President Washington drew the Court's first six Justices from around the country, evidently attempting to balance the Court geographically to avoid any sectional bias. ${ }^{46}$ Congress chose to fix the Court's location at the nation's center, in what later became the District of Columbia. By 1800, the Court was thus structured to employ Justices from an array of states and to deliberate outside the territorial boundaries of any one of the states. Amar plausibly contends that such a tribunal would more impartially resolve interstate disputes than the federal trial courts, which sit within state boundaries and typically employ judges from within the state.

Amar's geographic account finds support in Supreme Court decisions that emphasize the Court's neutrality and the nationwide reach of its original process. In Ohio v. Wyandotte Chemicals Corp., Justice Harlan identifies two principles that underlie the grant of original jurisdiction:

43. Amar, supra note 10 , at $469-78$.

44. See id. at 489-90. Amar presents his geographic argument in support of Chief Justice Marshall's holding in Marbury v. Madison, 5 U.S. (1 Cranch) 137 (1803), that Congress lacks powcr to confer original jurisdiction on the Court except in the state-party and ambassador cases that Article III assigns to it. See Amar, supra note 10, at 463-64, 469-77.

Amar's argument fails to persuade for a variety of reasons, detailed in the text. In addition to thesc, much of the evidence that Amar deploys in support of his geographic argument comes from debates over federal diversity jurisdiction over non-citizen defendants. See Daniel J. Meltzer, The History and Structure of Article III, 138 U. PA. L. REv. 1569, I605-08 (1990). Such claims were not made a part of the Court's original cognizance under any conceivable theory of the clause.

45. Amar, supra note 10 , at 477 . The Court does offer a geographically neutral, and relatively convenient, forum for the resolution of two kinds of disputes that were considercd candidatcs for original adjudication: impeachments and territorial disputes between the states.

46. See Bernard Schwartz, A History of the Supreme Court 17 (1993) (observing that six states were represented among Washington's judicial appointees and noting the importance of "geographic dispersion"). 
The first was the belief that no State should be compelled to resort to the tribunals of other States for redress, since parochial factors might often lead to the appearance, if not the reality, of partiality to one's own. The second was that a State, needing an alternative forum, of necessity had to resort to this Court in order to obtain a tribunal competent to exercise jurisdiction over the acts of nonresidents of the aggrieved State. ${ }^{47}$

Harlan thus views the Court's original docket as having been designed as a favor to plaintiff states-a forum they could use to overcome their own courts' inability, given the prevailing territorial assumptions of the day, to exercise in personam jurisdiction over nonresidents. ${ }^{48}$ Harlan also emphasizes the impartiality of the Supreme Court's original docket, although he appears to stress the Court's inpartiality vis-á-vis state courts.

Yet, like the dignified tribunal account, Amar's geographic explanation of the Court's original jurisdiction remains incomplete. Amar's geographic argument rests on the dubious assumption that the Supreine Court, as well as "Ambassadors, other public Ministers, and Consuls," were permanently stationed in the capital. Consuls, for one, represented their countries in the admiralty courts of the United States and were often heard in maritime centers far from the District of Columbia. ${ }^{49}$ Nor did the framers necessarily envision that the Court would sit only at the seat of government; its location was not fixed in the Constitution. Madison and others expressed the view in the ratification debates that the Supreme Court might move around the countryside. ${ }^{50}$ Indeed, one finds support for such a mobile conception of the Court's original docket in the circuit riding duties that

47. 401 U.S. 493, 500 (1971) (citations omitted). Chief Justice Jay also spoke of the importance of an impartial forum. He offered the following account of the jurisdictional grant over disputes between states as plaintiffs and diverse citizens:

[I]n case a state (that is, all the citizens of it) has demands against some citizens of another state, it is bettcr that she should prosecute their demands in a national court, than in a court of the state to which those citizens belong; the danger of irritation and criminations arising from apprehensions and suspicions of partiality, being thereby obviated.

Chisholm v. Georgia, 2 U.S. (2 Dall.) 419, 475-76 (1793).

48. Commentators conventionally trace the territorial approach to jurisdiction to the Court's Gilded Age opinion in Pennoyer v. Neff, 95 U.S. 714 (1878), overruled in part by Shaffer v. Heitner, 433 U.S. 186 (1977), but the same territorial assumptions underlay the assertion of jurisdiction at the time of the framing; see Bumham v. Superior Court, 495 U.S. 604, 610-11 (1990) (citing a 1793 Connecticut case and an 1819 Massachusetts case). To cite just one example, the Judiciary Act of 1789 explicitly forbade the newly created federal district courts, which were limited by the territorial borders of the states in which they sat, from hearing civil suits "against an inhabitant of the United States, by any original process in any other district than that whereof he is an inhabitant, or in which he shall be found at the time of serving the writ." Judiciary Act of 1789, ch. 20, $\$ 11,1$ Stat. 73, 79.

49. See, e.g., Moodie v. The Ship Phoebe Anne, 3 U.S. (3 Dall.) 319 (1796) (British consul appeared in admiralty action in South Carolina); United States v. Lawrence, 3 U.S. (3 Dall.) 42 (1795) (French consul appeared in New York action).

50. Oliver Ellsworth's "Landholder" letters reflect the possibility that the Court would convene in different districts or perhaps in each of the states. See Oliver Ellsworth, The Landholder (No: VI) (Dec. 10, 1787), in Essays ON THE Constitution OF THE UNITEd STATES 161, 164 (Burt Franklin 1970) (Faul L. Ford ed., 1892). Madison made his argument to the same effect with custoniary thoroughness: 
Congress imposed on the Justices in the Judiciary Act of 1789.51 Such duties were repeatedly attacked as an unconstitutional extension of the Court's original jurisdiction, ${ }^{52}$ a claim that underscores the close connection

I am of opinion (and my reasoning and conclusions are drawn from facts) that, as far as the power of Congress can extend, the judicial power will be accommodated to every part of America. Under this conviction I conclude that the legislation, instead of making the Supreme Federal Court absolutely stationary, will fix it in different parts of the continent, to render it more convenient. I think this idea perfectly warrantable. There is an example, within our knowledge, which illustrates it. By the Confederation, Congress have an exclusive right of establishing rules for deciding, in all cases, what captures should be legal, and establishing courts for determining such cases finally. A court was established for that purpose, which was at first stationary. Experience, and the desire of accommodating the decision of this court to the convenience of the citizens of the different parts of America, had this effect-it soon became a regulation that this court should be hcld in different parts of America and it was held accordingly.

3 The Debates in the Several State Conventions on the Adoption of the Federal Constrtution 535-36 (Jonathan Elliot ed., 1836) (hereinafter ElLiot's Debatesl (remarks of James Madison); cf. Henry J. Bourguignon, The First Federal Court: The Federal appellate Prizb Court of the AMERICAN Revolution, 1775-1787, at 337 n.40 (1977) (questioning the accuracy of Madison's recollection as to the mobility of the Court of Appeals in capture and prize cascs). Madison admits that geographical convenience concerned the framers; he argued, however that it was a matter for Congress to address, not one that Article III had finally resolved. Cf. Letter from Robert Treat Paine to Caleb Strong (May 18, 1789), in 4 DOCuMENTARY HISTORY OF THE SUPREME CourT, supra note 4I, at 392, 393 ("I think the fed. Sup. Jud. will be Itinerant \& the trial of Appealed Causes So regulated as to prevent as much as may be the expense and burthen of going far from home for Justice."); Letter from Edmund Pendleton to James Madison (July 3, I789), in 4 Documentary History of the Supremb Court, supra note 41, at 444, 445 ("The Circuit part of the Plan [of the Judiciary Act] suggests a thought worthy of Attention; whether the Supreme Court might not sit in each of those Circuits, instead of being Stationary."); Essays of Brutus (No. XIV, cont.) (March 6, 1788), in 2 ThB Completr ANTIFeDERALIST 433, 434 (Herbert J. Storing ed., 198I) ("No man can say where the supreme court are to hold their sessions ....."); 3 Elliot's DebaTEs, supra, at 558 (remarks by John Marshall) ("Does the constitution say ... that the Supreme Court shall be held in the ten miles square?").

51. For useful summaries of circuit riding, the burdens it imposed on the Justices of the Supreme Court, and the objections they repeatedly raised against it, see I Charles Warren, The SUPremb Court in UNTTED STATES History 85-90 (1922); Wythe Holt, "The Federal Courts Have Enemies in All who Fear Their Influence on State Objects": The Failure to Abolish Supreme Court Circuit Riding in the Judiciary Acts of 1792 and 1793, 36 BuFr. L. REv. 30I (1987) [hereinafter Holt, "The Federal Courts Have Enemies"]. On the wide range of proposals to ensure mobility on the part of the Supreme Court that came before Congress in drafting the Judiciary Act of 1789, see Wythe Holt, "To Establish Justice": Politics, the Judiciary Act of I789, and the Invention of the Federal Courts, 1989 DukB L.J. 1421, 1490-93 [hereinafter Holt, "To Establish Justice"] (describing the consideration and rejection of the British nisi prius model in which justices rode circuit from the center). See generally WILPRED J. Ritz, Rewrinting the History of the Judiciary Act of I789: Exposino Myths, Challenaino Premises, and Usino New Evidence 63 (1990) (noting mobility of most state superior courts; describing Article III as "sufficiently flexible so that the Supreme Court could have devcloped as a superior court with trial jurisdiction over the entire country").

52. Perhaps the best-known such attack came from sitting Associate Justice Samuel Chase, who argued that the circuits involved an unconstitutional extension of the Court's original jurisdiction. See Letter from Samuel Chase to John Marshall (April 24, 1802), in George L. Haskins \& HzRgert A. Johnson, Foundations of Power: John Marshall, 1801-15, at 172-77 \& n.I82 (The Oliver Wendell Holmes Devise History of the Supreme Court of the United States, vol. 2, Paul A. Frcund ed., 1981). When the issue was presented to the Supreme Court, the constitutional question was brushed aside as one that had been settled by prior practice. See Stuart v. Laird, 5 U.S. (I Cranch) 299, 306 (1803). See generally David P. Currie, The Constitution in the Supreme Court: The Powers of the Federal Courts, I80I-1835, 49 U. CH1. L. REv. 646, 663-64 (1982) (discussing the constitutional issues presented by circuit riding duties). 
between circuit riding and mobile Supreme Court original jurisdiction. Original jurisdiction did not, therefore, necessarily entail dragging the parties to the center, as Amar claims. ${ }^{53}$

Apart from their questionable predicate, Amar's geographic considerations leave much unexplained. For one thing, Amar insists that Congress may deprive the Court of its original jurisdiction over state-party cases-a position at odds with the great weight of scholarly and judicial opinion. He thus has difficulty explaiming why Article III frames the grant of original jurisdiction in mandatory terms. Like the dignified tribunal account, moreover, Amar's geographic thesis fails to explain why the framers included states but excluded other sovereigns from the Court's original docket. The United States itself would enjoy convenient access to the Court's original docket, yet this party was omitted from the Original Jurisdiction Clause. Much the same can be said of the clause's omission of claims involving foreign nations, whose envoys would have been posted to the capital. ${ }^{54}$

In any case, experience has demonstrated that state and lower federal courts can conveniently handle a good many of the claims that fall within the Court's original jurisdiction. This competing convenience argument doubtless partly explains why the Court has upheld the power of Congress to vest such inferior tribunals with concurrent jurisdiction over matters within the Court's original cognizance. As the Court explained in Ames $v$. Kansas, ${ }^{55}$ the exercise of concurrent jurisdiction by such inferior tribunals over clainis involving the states operates to avoid converting "what was intended as a favor into a burden."56

Although Amar's claims of geographic neutrality and convenience do not offer a persuasive account of the function of the Court's original docket, we need not reject them out of hand. Instead, we should understand those concerns as properly informing the allocation of federal jurisdiction as between the Supreme and inferior tribunals. Amar's argument from geographical convenience coincides with the established understanding that Congress may vest lower federal courts with cognizance of certain cases on the original docket. I suggest in Part V that Amar's considerations of con-

53. Even if one assumes that they contemplated a fixed location for the Court at the seat of government, as the Judiciary Act later provided, the framers need not have viewed the fact-finding component of original litigation as placing an intolerably greater burden on the parties than appellate litigation. Assuming that original litigation would require the parties to carry their witnesses and documents to the nation's center, Amar argues that this additional burden explains why the framers (might have) imposed limits on the Court's original docket. See supra text accompanying note 44 . But the Constitution, at least prior to the ratification of the Seventh Amendment, did not require the Court to engage in centralized fact-finding; indeed, the guarantee of jury trial extends only to suits at common law and permits the Court to use a decentralized fact-finding process in original cases that sound in equity. The Court typically follows the equity practice of appointing a master to take evidence in original cases-a practice that enables the Court's fact-finding machinery to visit the situs of the dispute. On the use of masters, see infra note 430.

54. See infra notes 234-36 and accompanying text.

55. 111 U.S. 449 (1884).

56. Id. at 464 . 
venience and neutrality should inform the distribution of state-party jurisdiction to the inferior federal courts. ${ }^{57}$

\section{The Puzzling Exclusion of Federal Questions from the Scope of Original Jurisdiction}

The Court's willingness in Wyandotte Chemicals and Louisiana $v$. Cummins to refrain fron hearing cases within its original jurisdiction casts doubt not only on the dignified tribunal argument and the geographic convenience rationale but also on the leading account of the scope of the Court's origiual jurisdiction. Justice Harlan's justification in Wyandotte Chemicals for the Court's discretion to shunt cases from its original docket emphasizes the Court's desire to preserve its scarce resources, original and appellate, for the resolution of claims that present federal questions. ${ }^{58}$ Yet, although Harlan's federal law focus makes eminently good sense, the Court has long refused to recognize the existence of a federal question as providing an independent source of original jurisdiction in a case involving state parties. Since dicta to that effect first appeared in Cohens $v$. Virginia, ${ }^{59}$ the Court has indicated that its original docket depends entirely on the align-

57. See supra note 50 .

58. 401 U.S. 493, 497-99 (1971); see also Martin v. Hunter's Lessee, 14 U.S. (1 Wheat.) 304, 335-36 (1816) (noting the "vital importance" of the federal question cases enumerated in the first category of Article III's jurisdictional menu); Cohens v. Virginia, 19 U.S. (6 Wheat.) 264, 391 (1821) (noting that concerns with the partiality of state courts may have justified the grant of jurisdiction over party-alignment controversies, but suggesting that this concern with partiality was not "the sole nor the greatest object for which this department was created. A more important, a much more interesting, object was, the preservation of the constitution and laws of the United States, so far as they can be preserved by judicial authority"); see also Amar, supra note 12, at 246-54 and sources cited thcrcin.

Such an approach understandably recognizes both that the Court owes a paramount duty to secure the uniform and effective enforeement of federal law and that its role in state law cases, especially after Erie Railroad Co. v. Tompkins, 304 U.S. 64 (1938), seems far less significant. Harlan's approach to original jurisdiction mirrors in some respects the Court's longstanding refusal to undertake appellate review in the absence of a controlling question of supreme federal law.

The Court has never enjoyed a statutory grant of appellate jurisdiction to review state court decisions in controversies betwecn diverse parties that fail to present a federal question. From the famous section 25 of the Judiciary Act of 1789 to the current codification, the Court's appellate jurisdiction has never been extended to state court decisions that do not present federal questions. Compare Judiciary Act of 1789, ch. 20, $\$ 25,1$ Stat. 73, 85-87 (authorizing the Court to review final state court decisions that reject a right or title set up under Federal Constitution, law, or trcaty) with 28 U.S.C. $\$ 1257$ (1988) (authorizing review by certiorari of final state court decisions that draw into question the Constitution, laws, and treaties of the United States). The decision in Murdock v. Memphis, 87 U.S. (20 Wall.) 590 (1875), further limited the Court's power to review state law questions that come to the Court alongside controlling questions of federal law. Indecd, the adequate and independent state ground doctrine, which flows from Murdock, precludes the Court from reviewing federal questions whenever the decision below rests on an adequate and independent state law ground. See generally Alfred Hill, The Inadequate State Ground, 65 Colum. L. Rev. 943 (1965); Terrance Sandalow, Henry v. Mississippi and the Adequate State Ground: Proposals for a Revised Doctrine, 1965 Sup. CT. Rev. 187.

59. 19 U.S. (6 Wheat.) $264,393-94$ (1821) ("When, then, the constitution declares the jurisdietion, in cases where a state shall be a party, to be original ... [the] framers designed to include in [this] class, those cases in which jurisdiction is given, because a state is a party . . . ."). 
ment of parties. ${ }^{60}$ The Court exercises jurisdiction over claims involving the United States and the states, those between two or more states, those between states as plaintiffs and the citizens of other states, and those between states as plaintiffs and foreign citizens, subjects, and countries. ${ }^{61}$ As a result of the Court's focus on party alignments, its original jurisdiction may not be invoked by or against the states in federal question cases that do not also satisfy the requirements of diversity. ${ }^{62}$

The Court's declared concern with assigning priority to federal law disputes is at odds with its refusal to assert jurisdiction in the absence of the required party alignments. In Oregon $v$. Mitchell ${ }^{63}$ and South Carolina $v$. Katzenbach, ${ }^{64}$ the Court agreed to hear claims brought by states to enjoin the Attomey General of the United States from implementing allegedly unconstitutional voting rights legislation. The considerable importance of these federal claims explains why the Court agreed to hear them; yet the Court's jurisdiction depended on the essentially fortuitous fact that Oregon and South Carolina prosecuted their claims against individual Attorneys General who were citizens of other states. The divergence between the (nominal) party-alignment predicate for its assertion of original jurisdiction and the (real) federal question core of the many cases that appear on its original docket points up a troubling inconsistency in the Court's management of its original docket. ${ }^{65}$

The curious discontinuity between the Court's party-driven original jurisdiction and its federal question preoccupation finds an equally curious refiection in the jurisdictional statutes that govern the federal district courts. Shortly after Congress conferred general federal question jurisdiction upon

60. Consider the Court's leading statement on the party-alignment focus of its original jurisdiction:

The original jurisdiction depends solely on the character of the parties, and is confined to the cases in which are those enumerated parties and those only. Among those in which jurisdiction must be exercised in the appellate form are cases arising under the Constitution and laws of the United States. In one description of cases the character of the parties is everything, the nature of the case nothing. In the other description of cases the nature of the case is everything, the character of the parties nothing.

Califomia v. Southem Pacific Co., 157 U.S. 229, 257-58 (1895) (dictum); see also Texas v. Interstate Commerce Comm'n, 258 U.S. 158 (1922) (dismissing a state's original federal-question action on grounds that a citizen of plaintiff state, a non-diverse party, appeared as a defendant).

61. See 28 U.S.C. \& 1251(a), (b) (1988).

62. See, e.g., Texas v. Interstate Commerce Comm'n, 258 U.S. at 163-65. In actions brought by the United States, the Court has rclaxed its demand for literal adherence to Article III party alignments. See HART \& WECHSLER, supra note 10 , at 305.

63. 400 U.S. 112 (1970).

64. 383 U.S. 301 (1966).

65. See also South Carolina v. Regan, 465 U.S. 367 (1984), an action brought by the State of South Carolina against the Secretary of the Treasury to challenge the constitutionality of a federal tax. While the nominal defendant, Donald Regan, happened not to come from South Carolima, he might well have. If he had, the Court would have faced a constitutional quandary-how to obtain original jurisdiction over a case presenting a weighty federal question without violating its jurisdictional limits in the process. 
inferior federal courts in $1875,^{66}$ the Court held that the courts could assert such jurisdiction over claims brought by state parties. ${ }^{67}$ But while the lower federal courts' authority to proceed in federal question cases remains well established, ${ }^{68}$ such courts have no authority to hear diversity claims brought by state plaintiffs or against state defendants. ${ }^{69}$ We thus confront a situation in which the Supreme Court, in disputes involving states, enjoys diversity jurisdiction, but no federal question jurisdiction, and the federal district courts enjoy federal question jurisdiction but no diversity jurisdiction.

That the text of Article III does not compel such a topsy-turvy jurisdictional world emerges from the opinion of the first Justice Harlan in the Court's leading departure from its party-alignment dogma, United States $v$. Texas. ${ }^{70}$ There, the Court asserted jurisdiction over federal question claims brought by the United States against the State of Texas. Harlan begins his opinion for the Court with a structural argunient: on the theory of the case advanced by Texas, ${ }^{71}$ no federal court would have had jurisdiction over the boundary dispute, despite the fact that it presented a federal question. ${ }^{72}$

66. For an account of Congress' decision to vest the federal courts with jurisdiction over cases arising under the Constitution, laws, and treaties of the United States, now codified at 28 U.S.C. $\$ 1331$, see HART \& WEChSLER, supra note 10, at 960-66.

67. See Ames v. Kansas, 111 U.S. 449, $462-72$ (1884). In Ames, Kansas had brought suit in its own courts to challenge a corporate consolidation by the Kansas Pacific Railway Company. The defendant removed the action, contending that it arose under federal law within the meaning of both the general federal question statute and the relevant removal provisions. Among other arguments, Kansas contended, unsuccessfully, that the Court's original jurisdiction over claims brought by the states was exclusive and therefore barred Congress from vesting the lower federal courts with such jurisdiction. Id. at $457-59$.

68. See, e.g., Texas v. Pankey, 441 F.2d 236, 238-39 (10th Cir. 1971) (upholding powcr of district courts to entertain action brought by Texas against a citizen of another state; commending Texas for choosing the federal district court to avoid burdening the Supreme Court's original dockct).

69. See 28 U.S.C. $\S 1332$ (a) (1988) (extending the diversity jurisdiction of the federal district courts to civil actions exceeding the $\$ 50,000$ amount-in-controversy threshold between "(1) citizens of different States; (2) citizens of a State and citizens or subjects of a foreign state; (3) citizens of different States and in which citizens or subjects of a foreign state are additional parties; and (4) a forcign state ... as plaintiff, and citizens of a State or of different States," but including no provision for actions initiated by or against the States themselves).

70. 143 U.S. $621,644-45$ (1892). Like the bulk of cases on the Court's original docket, United States $v$. Texas grew out of a dispute over the location of a territorial boundary. The United States filed an original bill in the Supreme Court secking an adjudication that the disputed land, known as "Grcer County," lay within the territory of the United States. 1t was already well settled that disputes between states over boundary lines presented federal questions and that such disputes were justiciable by the federal courts, sitting in equity, despite their political charaeter. Id. at 639-40.

71. Texas advanced the traditional argument that the Court's constitutional grant of original jurisdiction depended entirely on the diversity of the parties to the cause and hence incorporatcd by reference each of the heads of "controversy" jurisdietion on the jurisdictional menu that include the state as a party. Id. at 626-29. Texas then observed that although the menu included controversies between two or more states and controversies between states and diverse citizens, aliens, and forcign nations, it did not include controversies between the United States and one or more of the states. Arguing that the Judiciary Act tracked Article III, Texas contended on both constitutional and statutory grounds that the Court lacked original jurisdietion. Id.

72. Such a conclusion would have required the parties to resolve their differcnces by submitting them either to a state court in Texas or to a test of physical strength. Harlan viewed the first alternative 
Harlan then turned to the text of Article WI, noting its distinction between "cases," in which "the jurisdiction of the courts of the Union depends "on the character of the cause, whoever may be the parties," " and "controversies," in which jurisdiction depends "on the character of the parties, whatever may be the subject of controversy." "73 $\mathrm{He}$ drew a connection between the provision of the jurisdictional menu that extended the judicial power to "all cases ... arising under this Constitution, the laws of the United States, and treaties made" and the grant of original jurisdiction " in all cases . . . in which a State shall be party." "74 Harlan concluded that the Constitution had conferred power on the Court to hear "all cases mentioned in the [jurisdictional menu] in which a State may, of right, be made a party defendant, as well as in all cases in which a State may, of right, institute a suit in a court of the Umited States."75

Harlan's conclusion that Article III provides for the assertion of original jurisdiction over federal question "cases" involving the state as a party" did not take hold. While the Court has reaffirmed its holding that the United States may invoke the Court's original jurisdiction in a dispute with the states, ${ }^{77}$ it has refused to accept Harlan's view that non-diverse federal

as inconsistent with the framers' conclusion that the federal government would enforce its claims in its own courts, free from dependence on "the mercy of the States." Id. at 641 (quoting Justice Story). The second alternative, Harlan observed, had no place in a constitutional system and "cannot be contemplated by any patriot except with feelings of deep coneern." Id.

73. Id. at 643 (quoting Cohens v. Virginia, 19 U.S. (6 Wheat) 264, 378 (1821)); see also infra notes 199-204 and accompanying text.

74. United States v. Texas, 143 U.S. at $642-43$ (quoting U.S. Consr. art. III, § 2, cls. 1, 2).

75. Id. at 644 .

76. After concluding that the State-party Clause encompassed federal question cases in which the state appears as a proper party, Harlan addressed the significance of the Judiciary Act. Texas had argued that the Act's provision for exclusive original jurisdiction embraced only suits betwcen a state and another state or foreign country, adopting the traditional position that the term "controversies" in the Act referred only to the state-party controversies on the menu. Harlan answered that argument by explaining that the Act's reference to "controversies" was broad enough to encompass claims brought by the United States against a state. But, at bottom, Harlan viewed the statutory terms as beside the point in keeping with the Court's view of its original jurisdiction as mandatory and self-executing: "[W]e do not perceive upon what sound rule of construction suits [of the character before the Court] are to be excluded from its original jurisdiction as defined in the Constitution." Id.

77. See, e.g., United States v. Louisiana, 389 U.S. 155 (1967) (determining measurement of seaward boundaries of Texas); United States v. Califomia, 332 U.S. 19 (1947) (determining that federal govemment rather than state government has paramount rights over certain submerged land off the California coast).

Justice Frankfurter later asserted that Justice Harlan had departed from the literal terms of the Constitution. Frankfurter suggested that the practical necessity of affording a tribunal led the Court to assert jurisdiction over claims by the United States, "although the merely literal language of the Constitution precluded it (as the dissent in that case insisted)." Ex parte Republic of Peru, 318 U.S. 578, 598 (1943) (Frankfurter, J., dissenting). Frankfurter reads Harlan's opinion less as a repudiation of the party-alignment orthodoxy than as a textually dubious addition of the United States as a party authorized to invoke the Court's original jurisdiction in cases involving the states.

Despite Frankfurter's doubts, substantial historical support exists for reading the Court's original jurisdiction as encompassing controversies between the United States and a state, even if one accepts (as I do not) the Court's assumption that its original jurisdiction focuses exclusively on party aligninents. As originally drafted, the U.S.-party provision expressly embraced controversies between the United 
question cases involving the state as a party fall within the Court's constitutionally conferred original jurisdiction. Instead, it has returned to its preoccupation with parties, holding that it lacks jurisdiction over federal claims brought by states that name defendants who fail to conform to the party alignments in Article III. ${ }^{78}$

Recent codifications of the Court's original jurisdiction by Congress demonstrate a similar party-alignment preoccupation. Although Congress responded to the decision in United States $v$. Texas by adding "controversies" between the United States and a state to the Court's original docket, it has failed to authorize the Court to assert original jurisdiction over federal question cases that involve state parties. The current codification thus bears a striking reseinblance to the focus on party alignments that first appeared in section 13 of the Judiciary Act of 1789. It provides the Court with original and exclusive jurisdiction of "all controversies between two or more States"79 and original but nonexclusive jurisdiction over "controversies between the United States and a State" and over actions brought "by a State against the citizens of another State or against aliens." ${ }^{80}$

States as a party and one or more states or citizens. See 2 ThE RECORdS OF THE FEDERAL CONVENTION OF 1787, at 342 (Max Farrand ed., 1911) [hereinafter Records of THE Federal Convention]. Although the final language chosen refers more generally to controversies to which the U.S. shall be a party, the Convention apparently assumed that disputes between the United States and the statcs wcre encompassed within the clause. See id. at 465 ("Mr. Madison considered the claim of the U.S. [to territories involved in disputes with the states] as in fact favored by the jurisdiction of the Judicial power of the $\mathrm{U}-\mathrm{S}$ - over controversies to which they should be parties.").

78. In his dissenting opinion in United States v. Texas, Chief Justice Fuller had this to say: "Our original jurisdiction, which depends solely upon the character of the parties, is confined to the cases enumerated, in which a State may be a party, and this-is not one of them." 143 U.S. at 649 (Fuller, C.J., dissenting). Fuller later wrote for the Court in Califomia v. Southem Pacific Co., 157 U.S. 229 (1895), in which he rejected the implications of United States $v$. Texas. See supra note 60.

The Court's adherence to a party-based original jurisdiction jurisprudence despite United States $v$. Texas has becn noted by a variety of distinguished scholars. In several seetions of their well-known text, Hart and Wechsler describe the Court's original docket as principally consisting of the state-party "controversies" defined in Article III. See HART \& WechsLer, supra note 10, at 33 (describing the party-based extension of original jurisdiction in section 13 of the Judiciary Act of 1789 as "nearly but not exactly coextensive with the constitutional grant" despite the fact that section 13 failed to confer original jurisdiction in cases arising under federal law); id. at 304 (suggesting that the decisions in United States $v$. Texas and Texas $v$. Interstate Commerce Comm' $n$ might be reconciled by reading the Original Jurisdiction Clause to encompass "only . . . those classes of cases in the first clause which are described in terms of parties rather than of subject inatter"-a position consistent with the overwhelming weight of scholarly opinion); see also ERWIN CHEMERINSKY, FEDERAL JURISDICTION 50003 (1989); Amar, supra note 10, at 488-93; Amar, supra note 12, at $244 \mathrm{n} .128$ (contending that Original Jurisdiction State-party Clause's use of "cases" is equivalent to jurisdictional inenu's use of "controversies"); Massey, supra nòte 4, at 117 n.288; Lawrence G. Sager, The Supreme Court, 1980 Term-Foreword: Constitutional Limitations on Congress' Authority to Regulate the Jurisdiction of the Federal Courts, 95 HaRv. L. REv. 17, 24 n.19 (1981) (noting the party-alignment focus of the current statute and suggesting that Article III may encompass other cases). But see 17 WRIGHT \& MLLER, supra note $10, \S 4049$.

79. See 28 U.S.C. § 1251(b)(2) (1988).

80. Id. § 1251(a), (b)(3). 
The party focus assures the Court a continuing diet of the kind of disputes ordinarily associated with diversity jurisdiction and requires the Court to limit access to its original docket through the discretionary doctrine articulated in Wyandotte Chemicals., Although the Court continues to resolve serious interstate boundary and water disputes, it also confronts actions on its original docket that address such forgettable questions as the obligation of one state to perform a contract to play college football. ${ }^{81}$ No wonder Professor Gunther ignores the Court's original jurisdiction in his constitutional law text.

As the remainder of the Article attempts to show, such a dismissive attitude more aptly applies to the current configuration of the Court's original practice than to the framers' conception of the role of the Court's original jurisdiction in the constitutional plan. The next Part lays the groundwork for a better understanding of the framers' intentions by examining the two considerations that appear to have led to the grant of original jurisdiction. It first examines the doctrine of state sovereign immunity that confronted the framers and then considers why that doctrine, coupled with the Madisonian compromise, necessitated original federal jurisdiction in state-party cases.

\section{II}

Structural Barriers to Judicial ENForcement of the Federal Scheme: Between State Sovereign

IMMUNITY AND THE MADISONIAN COMPROMISE

Debates in the literature over the scope of state immunity from suit in federal court ordinarily focus on Chisholm v. Georgia and the subsequent ratification of the Eleventh Amendment. Yet the key to a more complete understanding of state immunity under the Constitution - the grant of original jurisdiction in state-party cases that the Court invoked in Chisholmhas rarely received even passing attention. ${ }^{82}$ In this Part, I re-examine the framers' understanding of state sovereign immunity, building on the work of Eleventh Amendment theorists. I show that, had Article III failed to confer something like an affirmative grant of original jurisdiction in stateparty cases, the framers would have had good reason to fear that states would successfully claim immunity from suit.

81. See, e.g., California v. West Virginia, 454 U.S. 1027 (1981) (denying leave to file original action for breach of contract to play college football game); Maryland v. Louisiana, 451 U.S. 725 (1981) (denying leave to file in dispute over collection of state taxes); Illinois v. Michigan, 409 U.S. 36 (1972) (action to enforce reciprocal insurance statute); Arizona v. California, 377 U.S. 926 (1964) (suit to recover modest amount of workers' compensation benefits); Louisiana v. Western Reserve Historical Soc'y, 465 U.S. 1018 (1984) (action to recover Louisiana survey documents).

82. For passing references to the Court's original jurisdiction by Eleventh Amendment theorists, see Akhil R. Amar, Of Sovereignty and Federalism, 96 YALE L.J. 1425, 1470 n.188 (I987); Massey, supra note 4 , at 117 n.288. 
After re-examining the doctrine of state sovereign immunity that confronted the framers, I explore a second significant hurdle to the effective enforcement of federal law against the states. The Madisonian compromise resolved a dispute between those at the Philadelphia convention who sought constitutionally to mandate the creation of inferior federal tribunals and those who preferred to leave original cognizance of federal judicial business to the state courts. Madison and Wilson resolved the impasse by proposing to authorize, but not require, Congress to institute inferior federal tribunals. ${ }^{83}$ Such a compromise raised the prospect that Congress would implement Article III by relying upon state courts to hear federal claims originally. Congress' rehance on the state courts, when coupled with the doctrine of sovereign immunity, might preclude the effective enforcement of federal law against the states. In light of this concern, the Original Jurisdiction Clause expressed the framers' desire for an assured original docket for coercive claims against the states.

\section{A. State Sovereignty on the Eve of the Convention}

Two schools of thought prevail regarding the history of sovereign immunity in the period preceding the framing and ratification of the Constitution. ${ }^{84}$ One school claims that sovereign immunity was a fundamental precept of Anglo-American law. This understanding of history underlies what has been called the "profound shock" school of Eleventh Amendment thought: ${ }^{85}$ the perception that the Court's rejection of state sovereign immunity in Chisholm $v$. Georgia ${ }^{86}$ caused such a "shock of surprise"87 that it led the states to ratify the Eleventh Amendment to restore the original understanding. ${ }^{88}$ For these observers, sovereign immunity derived

83. On the Madisonian compromise, see Hart \& WeChSLER, supra note 10, at 10-11; Charles WARREN, The MAKING OF THE Constitution 267-313 (1928); see also David E. Engdahl, What's in a Name? The Constitutionality of Multiple "Supreme" Courts, 66 IND. L.J. 457, 476-77 (1991) (offering account of Madisonian compromise that emphasizes the parity of federal judges in the Supreme and inferior courts).

84. Many scholars have traced the doctrine of sovereign immunity during the period preceding the framing of the Constitution. See Clyde E. Jacobs, The Eleventh Amendment and Sovereion ImmunITy 3-I5 (1972); Amar, supra note 82, at 1429-39; Martha A. Field, The Eleventh Amendment and Other Sovereign Immunity Doctrines (pt. 1), 126 U. PA. L. REv. 515, 527-36 (1977); John J. Gibbons, The Eleventh Amendment and State Sovereign Immunity: A Reinterpretation, 83 CoLuM. L. REv. 1889, $1895-99$ (1983); Massey, supra note 4, at 87-97.

85. Charles Warren popularized the "profound shock" label一which he borrowed from Hans v. Louisiana, 134 U.S. 1, 11 (1890)-to describe the theory that Chisholm departed from contemporary understandings of the scope of state suability and that the Eleventh Amendment merely restored the original coneeption. See WARREN, supra note 51, at 96 ("The decision [in Chisholm] fell upon the country with a profound shock."). For an influential critique of the "profound shock" theory, see Gibbons, supra note 84 , at $1890-94$.

86. 2 U.S. (2 Dall.) 419 (1793).

87. Hans, 134 U.S. at 11.

88. The Eleventh Amendment provides that "[t]he Judicial power of the United States shall not be construed to extend to any suit in law or equity, commenced or prosecuted against one of the United States by Citizens of another State, or by Citizens or Subjects of any Foreign State." U.S. CoNST. 
from the common law conception that, as restated by Blackstone, "the King can do no wrong." 89 "Profound shock" theorists believe that states were accorded immunity following the Declaration of Independence and that the framers reaffirmed their immunity during the constitutional ratification debates..$^{90}$

In contrast to the "profound shock" school, much recent commentary offers a more limited account of the Eleventh Amendment that stems from a more complex view of the framers' understanding of sovereign immunity. ${ }^{91}$

amend. XI. Nineteenth and early twentieth century decisions more or less explicitly adopted the profound shock theory, and thus dramatically broadened the scope of state immunity to apply to proceedings that do not appear to come within the literal terms of the Eleventh Amendment. See Hans v. Louisiana, 134 U.S. 1 (1890) (holding that federal court may not entertain Contract Clause claim for contract damages brought by citizen against his own state); Principality of Monaco v. Mississippi, 292 U.S. 313 (1934) (reaching same result for action brought by foreign state); Ex parte New York, 256 U.S. 490 (1921) (reaching same result for action in admiralty).

89. 4 William Blackstone, Commentaries on the laws of England 254 (St. George Tucker ed., 1803).

90. "Profound shock" theories of the Eleventh Amendment rely extensively on the comments of Hamilton, Madison, and Marshall during the ratification debates. See, e.g., Hans, 134 U.S. at 11-15; Welch v. Texas Dep't of Highways \& Pub. Transp., 483 U.S. 468, $480-84$ \& n.10 (1987). For further discussion of these comments, see infra notes 290-327 and accompanying text. Like the revisionists, I find it significant that Federalists denied the suability of states only in the context of discussing the statediverse citizen head of jurisdiction. I also find wide-ranging support for the proposition that the Court's original jurisdiction was understood to effect a waiver of state immunity.

91. The strongest challenge to the profound shock account comes from scholars who propose a "diversity" reading of the Eleventh Amendnıent. In brief, the "diversity" theorists emphasize that Chisholm v. Georgia, 2 U.S. (2 Dall.) 419 (1793), a common law contract action, came to the Court on the basis of diversity between the plaintiff and the State of Georgia; no federal question or admiralty claim was presented. Revisionists then note the close correspondence between Article III's diverseparty grants of jurisdiction and the Eleventh Amendnient. They observe that the purpose of the Amendment was simply to deprive the federal courts of the two diverse-party heads of jurisdiction involving suits against states by individuals (citizens of other states or of other countries). On this view, they conclude that the Amendment left untouched the grants of federal question and adniralty jurisdiction. See generally Gibbons, supra note 84, at 1934-38; Amar, supra note 82, at 1473-92; William A. Fletcher, A Historical Interpretation of the Eleventh Amendment: A Narrow Construction of an Affirmative Grant of Jurisdiction Rather than a Prohibition Against Jurisdiction, 35 STAN. L. REv. 1033 (1983); Vicki C. Jackson, The Supreme Court, the Eleventh Amendment, and State Sovereign Immunity, 98 YALE L.J. 1 (1988).

The diversity account has recently been subjected to a searching critique. See Massey, supra note 4, at 65-66 (proposing a literal reading of the Eleventh Amendment that would withdraw all jurisdiction-party-based, federal question, and admiralty - whenever the plaintiff fits the amendment's description); Marshall, supra note 4, at 1342-49 (same).

Recent decisions of the Supreme Court reflect the mark of revisionist scholarship and the claim that the Eleventh Amendment operates only to withdraw two heads of diverse party jurisdiction from the grants in Article III. Justice Brennan, for exanple, has embraced the revisionist view, dissenting from decisions that apply the Eleventh Amendment bar to federal question cases and to those in admiralty. See Welch v. Texas Dep't of Highways \& Pub. Transp., 483 U.S. 468, 496-521 (1987) (Brennan, J., dissenting) (admiralty); Atascadero State Hosp. v. Scanlon, 473 U.S. 234, 258-302 (1985) (Brennan, J., dissenting) (federal question). Although Brennan's view attracted four votes in both Atascadero and Welch, he could not muster the fifth vote for overnuling Hans. Justice Scalia cast the decisive vote in Welch for preserving Hans, but did so for prudential reasons. Welch, 483 U.S. at 495-96. In the Court's most recent foray, Justice Scalia offered only a lukewarm endorsement of Hans but articulated a reluctance to abandon so long-standing and settled a doctrine. See Pennsylvania v. Union Gas Co., 491 U.S. 1, 30-35 (1989) (Scalia, J., concurring in part and dissenting in part). 
Revisionist accounts emphasize that even in Great Britain, the doctrine did not establish a complete bar to relief against either the crown or its officers. 92 In any event, argue opponents of the "profound shock" school, Americans had substituted the sovereignty of the people for the sovereignty of the crown and had secured limitations on governmental power through adoption of written constitutions. ${ }^{93}$ Judge Gibbons notes that the charters of many American colonies included provisions that authorized suit against the governing body. ${ }^{94}$ Like Professor Amar, ${ }^{95}$ Gibbons points to a range of state constitutional provisions that safeguard citizens' basic rights; ${ }^{96}$ such provisions affirm the ultimate sovereignty of the people. Amar emphasizes that nationalists argued vigorously that retaining the doctrine of state sovereign immunity was inconsistent with government by the people. ${ }^{97}$

Although they clash dramatically, the two prevailing accounts of state sovereign immunity share a common predicate-that the text and history of the Constitution fail unambiguously to answer the question of state suability. ${ }^{98}$ Thus, "profound shock" theorists tend to emphasize the Constitution's failure to offer the kind of clear statement necessary to override the fundamental doctrine of state sovereign immunity. Revisionists

92. Instead, Great Britain had evolved a series of alternatives to the invocation of common law remedies, most notably the petition of right, through which subjects of the crown could seek justice in legal petitions addressed to the King's ministers. See JACOBS, supra note 84, at 5-8; Gibbons, supra note 84, at 1895-96; Massey, supra note 4, at 87-88. In addition, the King's Bench in effect circumvented common law sovereign immunity by issuing the prerogative writ of mandamus to compel government officials to perform acts required of them by law. See Louis L. Jaffe, Suits Against Governments and Officers: Sovereign Immunity, 77 HARv. L. REv. 1, 16-18 (1963).

93. A prineipal exponent of the sovereignty of the people was James Wilson. His opinion in Chisholm rejected the notion of absolute sovereignty in governments and argued instead that sovereignty rested with the people. See Chisholm v. Georgia, 2 U.S. (2 Dall.) 419, 454 (1793) (Wilson, J.). The people thus had the right, acting through conventions assembled for the purpose, to trump the sovereignty of state governments. Wilson later elaborated his critique of Blackstone's conception of parliamentary sovereignty in his lectures on law. See 1 THE WORKS OF JAMES WILSON 79-81 (Robcrt G. McCloskey ed., 1967). For a vivid restatement of Wilson's conception of popular sovereignty, see Amar, supra note 82, at 1439-51. Professor Jensen comments critically on Wilson's efforts to obtain recognition of the higher sovereignty of the Union, his opposition to the recognition of state sovcrcignty in the Articles of Confederation, and his pecuniary motives for taking such positions. See MerriLL Jensen, The Articles of Confederation 154, 168-76 (1940); see also 1 Blackstone, supra note 89, app. at 352 (commentary by St. George Tucker) (arguing for amendments to both state and federal constitutions to abrogate sovereign immunity by providing for payment of funds to successful claimants against the government).

94. See Gibbons, supra note 84 , at $1896-97$.

95. See Amar, supra note 82 , at 1438-39.

96. See Gibbons, supra note 84 , at 1897-99.

97. Amar, supra note 82 , at 1439-51.

98. For comments on the ambiguity of the Constitution, see Massey, supra note 4, at 97 (" "The search for the original understanding on state sovereign immunity bears this much resemblance to the quest for the Holy Grail: there is enough to be found so that the faithful of whatever persuasion can find their heart's desire.' ") (quoting John V. ORth, The Judicial Power of THE UNITED States: The EleVENTH AMENDMENT In AMERICAN History 28 (1987)); see also JACOBS, supra note 84, at 39 (noting the ambiguities surrounding state suability under the state-diverse citizen head of jurisdiction); Fletcher, supra note 91, at 1069 ("[T] he extent to which the states could validly be made subject to federal law had becn answered only in the most general way ...."). 
agree that the constitutional record contains ambiguities; they argue instead that America had largely abandoned the doctrine, and no clear statement was necessary to incorporate state suabihity into Article III.

In this Section, I propose a new understanding of the framers' handling of state sovereign immunity which builds upon and extends the insights of both the profound shock and revisionist schools. I agree with revisionist accounts that emphasize the willingness of framers such as Wilson, Madison, and Hamilton to create a national government with coercive powers over the states. I also agree with profound shock theorists who argue that, absent a decisive break from established law, the doctrine of sovereign immunity would limit the authority of the federal courts to issue compulsive process to state sovereigns in their capacity as such. In contrast to both schools of thought, however, I claim that the Original Jurisdiction Clause effects a relatively unambiguous waiver of state immunity. Before taking up this thesis, I briefly review the origins of the doctrine of sovereign immunity in the pre-framing period and the shortcomings of traditional assessments of the doctrine.

Observers often fail to recognize that the doctrine of sovereign immunity at the time of the framing consisted of two related but somewhat independent elements. ${ }^{99}$ The first element, what I term "common law" sovereign immunity, barred individuals from bringing suit against the state in the state's own courts. This immunity flowed from the failure of the common law to develop a writ running against the King and lay at the heart of Justice Iredell's dissenting opinion in Chisholm. ${ }^{100}$ While certain states had created remedies analogous to the petition of right, ${ }^{101}$ such remedies required a legislative waiver of immunity.

99. The failure of scholars to note the distinction betweèn the states' common law and law-ofnations (in other courts) sovereign immunity may result from the general focus on the state-diverse citizen head of jurisdiction. That head of jurisdiction was the source of judicial power invoked by the Court in Chisholm v. Georgia, 2 U.S. (2 Dall.) 419 (1793), over Justice Iredell's strong common law immunity dissent. Id. at 429-49 (Iredell, J., dissenting).

As a consequence, scholars have misconstrued critical texts from the ratification era. Professor Massey, for example, characterizes as inaccurate Hamilton's sweeping statement of the scope of state sovereign immunity in The Federalist No. 81, see infra note 302, on the ground that it failed to account for the fact that states such as Virginia had opened their own courts to suits against themselves. See Massey, supra note 4, at 95-96. But Hamilton's statement was a perfectly accurate statement of immunity under the law of nations - an immunity that remained intact whatever the states might do to vitiate immunity in their own courts.

100. Iredell focused on the language of section 14 of the Judiciary Act of 1789 , with its provision for the issuance of writs according to the "principles and usages of law." Iredell construed this language as a reference to the common law of the states-the law inherited from Great Britain. After an exhaustive canvas of the leading decisions, Iredell concluded that the common law had failed to authorize process against the state. See Chisholm, 2 U.S. (2 Dall.) at 435-36, 449 (Iredell, J., dissenting).

101. Two well-known examples were the States of Georgia and Virginia. See Chisholm, 2 U.S. (2 Dall.) at 434 (Iredell, J., dissenting) (noting that Georgia had passed a statute providing for the assertion of claims against the state); 2 BLACKSTONE, supra note 89 , at $242-43$ n.5 (describing Virginia's procedure for redress of claims against the Commonwealth). 
In addition to common law immunity, states also enjoyed immunity from suit in the courts of another sovereign. This source of sovereign immunity owed less to the common law than to the law of nations. ${ }^{102}$

102. Other scholars have noted that the immunity claims of a sovereign differ depending on the forum in which the litigation proceeds. Then Professor Antonin Scalia, for exanuple, once remarked upon what he termed the "regrettable equation . . . between what might be called 'domestic' and 'foreign' sovereign immunity-that is, between the principles governing the anenability of a state to suit before its own courts and those governing its amenability to suit before the courts of another sovereign. Antonin Scalia, Sovereign Immunity and Nonstatutory Review of Federal Administrative Action: Some Conclusions from the Public-lands Cases, $68 \mathrm{MicH}$. L. Rev. 867, 886 (1970); see also Alfred Hayes, Private Claims Against Foreign Sovereigns, 38 HARv. L. REv. 599, 599 (1925) (distingnishing between the immunity of local and foreign sovcreigns and noting that the doctrine of exterritoriality might preclude action against a foreign sovereign upon a ground wholly inapplicable to the national sovereign"). My proposed distinction between comnion law and law-of-nations immunity may appear to echo Scalia's distinction between "domestic" and "foreign" sovereign immunity. But in the context of litigation in the state and federal courts of the United States, my approach differs from that of Scalia in two important respects.

On my account, the ordinary bar to the assertion of claims against the sovereign States in their own courts, what Scalia terms "domestic" immunity, flows from the conmon law. Such a common law prohibition of suits against the state was subject to abrogation either by legislative action or by consititutional provision. Virginia, for example, had authorized individuals to bring suit in the nature of a petition of right against the Commonwealth by the late 18th century but required the General Assembly to appropriate funds to pay any successful claimants. To that extcnt, the State maintaincd legislative control over the abrogation of immunity. See 1 BlACKsTone supra note 89, at App. 117. St. George Tucker characterized sucb retained legislative control as a "defect" in Virginia's constitution and went on to propose a constitutional amendment that would authorize money to be drawn on the public treasury in consequence of a judgment of the courts. Id. at App. 118. The common law rule of immunity in the sovereign's own courts was thus subject to both lcgislative and constitutional abrogation by the "domestic" sovereign.

The law-of-nations imnunity, which was applied by the Pennsylvania court in Nathan v. Virginia to dismiss an individual's action against the Conmonwealth of Virginia, differs from the common law immunity in terms of the local sovereign's powers of abrogation. Beeause those who applied it in Nathan understood the law-of-nations immunity to flow from the equal status of the two sovereign powers, Pennsylvania and Virginia, it followed that Pennsylvania lacked the power, by its own unilateral legislative or constitutional act, to abrogate Virginia's inmunity. The law of nations, in cases where it applied, appears to have erected a more formidable sovereign imnunity in the sense that it placed the immunity beyond the control of the local sovereign and in the hands of the sovereign against whom the proceedings were instituted. This difference apparently explains why Scalia regards the sovereign's "foreign" immunity -its immumity in another's courts-as the more substantial of the two.

Scalia apparently believes that states were competent (as Tucker argued) to abrogate their immunity from suit under the common law by authorizing suits against thenselves to go forward in their own courts. I share that view. Scalia also believes that, as of the date of the framing, a diffcrent order of imnunity was thought to apply to suits brought against the sovereign in the courts of other sovcreigns. 1 share that view, as well. We appear to disagree, however, on the extent to which the States' "forcign" or "law-of-nations" imnunity survived the framing of the Constitution. On my view, the Original Jurisdiction clause generally authorizes the assertion of jurisdiction over state-party cases and thus answers any argnments about the States' "foreign" immunity from suit in federal court. As Alexandcr Hamilton and others recognized, absolute immunity from suit in federal court was one of the attributcs of sovereignty that states chose to surrender in adopting the Constitution. See infra note 188 . To the extent that the grant of jurisdiction entails a constitutional abrogation of the law-of-nations immunity, I regard Scalia's concern with the subsequent erosion of the States' "foreign" imnunity as historically inapt.

A sccond disagreement flows from the first. Because Justice Scalia regards the States' forcign immunity from suit as having survived the framing, he (wrongly, I think) assumes that it provides the relevant limit on the power of the federal courts to hear suits against the States. I agree that State 
Under the law of nations as it was understood during and subsequent to the Revolutionary period, courts simply refused to entertain actions against other sovereigns. ${ }^{103}$ The immunity rested on the theory that all sovereigns were equal and independent and that one sovereign was therefore not obliged to submit to the jurisdiction of another's courts. ${ }^{104}$ Disputes between sovereign nations were to be resolved not through judicial process but through the negotiation of treaties, the exchange of ambassadors, and, if necessary, through war. ${ }^{105}$ Treatises on the law of nations widely recognized sovereign immunity as a limit on the power of one sovereign to adju-

immunity from suit may have survived the framing to a certain degree but I would trace such immunity to the English common law rather than to the law of nations. Here, I would build on Professor Fletcher's demonstration that the founding generation understood principles of general common law (of which English common law formed a part) to supply the rule of decision in much federal litigation. See William Fletcher, The General Common Law and Section 34 of the Judiciary Act of 1789: The Example of Marine Insurance, 97 Harv.L. Rev. 1513, 1517-27 (1984) (distinguishing between a federal common law and a general common law of the kind later disavowed in Erie that applied to disputes over which the federal courts otherwise enjoyed jurisdiction). Certainly, as I point out below, such an understanding of the continuing relevance of the common law immunity in federal court litigation involving the States squares with the accounts of sovereign immunity offered by both Hamilton and Madison. Similarly, Justice Iredell's analysis in Chisholm assumes the relevance of the common law rule to the determination of state immunity in an action over which the federal courts clearly enjoyed jurisdiction. See infra text accompanying note 205.

My disagreement with Scalia on the source of the surviving State immunity fron suit implies a further disagreement on the scope of the federal government's power to abrogate State sovereign immunity. By characterizing the States' retained immunity from suit in federal court as a "foreign" sovereign immunity, Scalia appears to argue for a relatively absolute bar to suit. On my account, by contrast, the law of nations immunity was set aside and left only the general rule of common law as a bar to suit against the States in federal court. Such a general common law rule of immunity would have survived any particular State's decision to authorize remedies against itself, just as Justice Iredell argued in focusing his Chisholm dissent on the general law of immunity and iguoring the fact that Georgia had made provision for suit against itself in its own courts. On my account, however, this general immunity from federal court litigation would give way to any supreme federal text, sucl as the Constitution, laws and treaties of the United States, that subjected states to a collcctive federal liability. Ultimately, therefore, I reject the apparent inplications of Scalia's neat distinction between "foreign" and "domestic" inımunity despite the fact that it appears to identify correctly the two inıortant sourees of immunity that confronted the framers of the Constitution.

103. See, e.g., Nathan v. Virginia, 1 U.S. (1 Dall.) 77 n.(a) (Pa. C.P. 1781). One can infer that this was the general practice of courts from treatises on the law of nations describing states as sovereign and independent. See infra note 104 and accompanying text.

104. Consider the statement of Chancellor Kent:

Nations are equal in respect to each other, and entitled to claim equal consideration for their rights, whatever may be their relative dimensions or strength, or however greatly they may differ in government, religion, or manners. This perfect equality, and entire independence of all distinct states, is a fundamental principle of public law.

$1 \mathrm{KENT}$, supra note 41 , at 21 . On the importance of Kent's Commentaries, see Lawrence M. Friedman, A History of American Law 288-92 (1973).

105. Thus, treatise writers on the law of nations discuss at length the rules governing the exchange of ambassadors, the negotiation and enforcenent of treaties, and the rules governing the declaration and conclusion of armed conflict. See, e.g., 1 KENT, supra note 41, at 1-208 (chapter on the law of nations); Monsieur de VATTEL, THE LAw of Nations 198-288 (Joseph Chitty ed., 1858) (treaties); id. at 452500 (ambassadors); id. at 291-427 (war and armed conflict). It was these methods of resolving disputes, of course, that the Constitution forbade to the states. The Constitution sought to substitute the rule of law for the settlement of inter-state disputes. See generally Charles WARREN, The SUPREME CourT AND Sovereign States (1924). 
dicate claims against another, ${ }^{106}$ as did the leading immumity decision of the Marshall Court, The Schooner Exchange v. McFaddon. ${ }^{107}$

During the period that preceded the framing, the states regarded themselves and one another as sovereign states within the meaning of the law of nations, thereby possessing law-of-nations sovereign immunity. ${ }^{108}$ The thirteen colonies, after all, had proclaimed to the international community in The Declaration of Independence that "these United Colonies are, and of Right ought to be Free and Independent States .. . [with] full Power to levy War, conclude Peace, contract Alliances, establish Commerce, and to do all other Acts and Things which Independent States may of right do."109 Similar language had been used in Article I of the Treaty of Peace of 1783, in which Great Britain acknowledged each of its former colonies to be "free, sovereign and independent States."110 Finally, the Articles of Confederation continued the pattern by proclaiming in Article II that "[e]ach state retains its sovereignty, freedom and independence, ... . which is not by this confederation expressly delegated to the United States."111

As a matter of law, then, the confederated states were regarded as fully fledged, immune sovereigns, except to the extent they had surrendered attributes of sovereignty through the Articles of Confederation. Yet the scope of any such surrender to national courts was quite limited. ${ }^{112}$ The jurisdiction of the only national courts established by the Articles was lim-

106. See 2 DE VATTEL, supra note 105 , at lxii, 155.

107. 11 U.S. (7 Cranch) 116, 135-46 (1812).

108. Early decisions of the Supreme Court acknowledged that the states had been sovereign entitics during the period between the Declaration of Independence and the ratification of the Constitution. See McIlvaine v. Coxe's Lessee, 8 U.S. (4 Cranch) 209, 212 (1808) (claiming that the "several states which composed this Union . . . became entitled, from the time when they declared themselves independent, to all the rights and powers of sovereign states"); Ware v. Hylton, 3 U.S. (3 Dall.) 199, 224 (1796) (describing the Declaration of Independence as establishing "not that the united colonies jointly, in a colleetive capacity, were independent states . . . but that each of them was a sovereign and independent state"); see also The Federalist No. 15, at 98 (Alexander Hamilton) (Jacob E. Cooke ed., 1961) (noting that "the concurrence of thirteen distinet sovereign wills is requisite under the confederation to the complete execution of every important measure"). But $c f$. United States v. Curtiss-Wright Export Corp., 299 U.S. 304, 316-17 (1936) ("[T]he states severally never possessed international powers .....").

109. The Declaration of Independence para. 2 (U.S. 1776), reprinted in 1 The Documentary History of the Ratification of the Constitution 75 (Merrill Jensen ed., 1976) [hereinaftcr DOCUMEnTARY History OF THE CONSTITUTION].

110. Frederick E. Hosen, UNFolding Westward in Treaty and Law 32 (1988) (reprinting 1783 Treaty of Peace).

111. 1 Documentary History of the Constitumon, supra note 109, at 86 . On the debales over state sovereignty that informed the adoption of Article II, see JENSEN, supra note 93, at 161-76.

The style of the Acts of Congress under the Articles of Confederation underscores this continuing deelaration of sovereignty and independence: each statute was inscribed both with the date "in the year of our Lord" and with the date detailing the number of years passed since the states' gaining of "[s]overeignty and [i]ndependence." See, e.g., 1 DOCUMENTARY History OF THE CONSTITUTION, supra note 109 , at 174.

112. Indeed, the Articles, in their deference to state sovereignty, rendered the national governmont ineffective in many ways. In addition to their extremely limited allowance for national courts, the Articles included no provision for the enforcement of state fiscal obligations, relying instead on the 
ited to hearing appeals from the state courts in cases of prize and capture ${ }^{113}$ and original disputes between states and citizens over boundary lands. ${ }^{114}$ The "courts" that exercised these limited powers were further hamstrung by their dependence on the states for the enforcement of their decrees. ${ }^{115}$ The limited scope of national judicial power thus prevented national courts from enforcing the obligations of the states to the confederation.

The law of nations similarly prevented one state's courts from enforcing another state's obligations. In the important 1781 decision of Nathan $v$. Virginia, ${ }^{116}$ the Court of Common Pleas of Pennsylvania effectively dismissed an action brought against the Commonwealth of Virginia by one Simon Nathan. The description of the case in the first volume of Dallas's reports suggests that Virginia followed the usual diplomatic course: it applied to the Supreme Executive Council of Pennsylvania, which directed the state's attorney general, William Bradford, to secure the action's dismissal. ${ }^{117}$ Bradford urged simply, and successfully, that the issuance of

willingness of the states to contribute their share to the expenses of the general government. See THE Federalist No. 15, at 93 (Alexander Hamilton) (Jacob E. Cooke ed., 1961).

113. Article IX of the Articles of Confederation empowered Congress to appoint courts to hear appeals from state courts in cases of capture. 1 DOCUMENTARY History OF THE ConstTtution, supra note 109, at 89. The Court of Appeals was a creation of Congress. For an admirable account of the work of the Court of Appeals in cases of prize and capture under the Articles of Confederation, see BouRguignon, supra note 50 .

114. Article IX of the Articles of Confederation provided that the United States, in Congress assembled, "shall also be the last resort on appeal in all disputes and differences now subsisting or that hereafter may arise between two or more states concerning boundary, jurisdiction or any other cause whatever." 1 DOCUMENTARY History Of THE CONSTITUTION, supra note 109, at 89-90. Article IX then went on to prescribe an elaborate procedure for the seleetion of commissioners or judges to resolve the controversy, as well as to include disputes between private citizens stemming from the land grants of two or more states. Id. at 90-91. For an account of the sole case in which this method of dispute resolution was invoked, see WARREN, supra note 105 , at 4-8.

115. On congressional efforts to strengthen the Court of Appeals' power in prize and capture cases, see Bourguignon, supra note 50, at 125-30. James Wilson was intimately acquainted with the difficulties faced, having represented Gideon Olmstead in prize litigation that eventually resulted in a decree in Olmstead's favor. Id. at 101-20, 329. Olmstead's efforts to enforce that decree were ultimately successful, but not until the federal courts had been established and vested with coercive powers over state officials. See United States v. Peters, 9 U.S. (5 Cranch) 115, 134-41 (1809) (compelling federal judge who ruled in Olmstead's favor to follow through on his judgment despite state law forbidding payment to the plaintiff). Professor Bourguignon hints that sucb personal experience explains why Wilson was such a vigorous advocate of vesting federal courts with admiralty jurisdiction. Bourguignon, supra note 50 , at 329 .

116. 1 U.S. (1 Dall.) 77 n.(a) (Pa. C.P. 1781).

117. Professor Fletcher ascribes some significance to the fact that Virginia proceeded in the action by approaching the executive arm of Pennsylvania to seeure the action's dismissal, rather than by entering an appearance in the case and arguing for the recognition of Virginia's immunity for suit. He notes that a similar procedure was followed in The Schooner Exchange v. McFaddon, 11 U.S. (7 Cranch) 116 (1812). See Fletcher, supra note 91, at 1075-76. From this, Professor Fletcher draws the conclusion that the doctrine of immunity may have been due in part to the "position taken by the forum executive rather than due solely to the inherent jurisdictional limitations of the forum." Id. at 1075 .

Fletcher's suggestion is certainly correct insofar as he argues that the doctrine of imnunity was not absolute. Marshall's opinion in The Schooner Exchange distingnishes betwecn vessels owned and operated by the sovereign in its sovereign capacity and those it operates for its private account. 11 U.S. (7 Crancb) at 143-44. But Professor Fletcher has placed too much reliance on the involvement in both 
process to Virginia violated the law of nations, which regarded each sovereign as equal and independent and thus immune from suit in another sovereign's courts. ${ }^{118}$

Although the Nathan case has occasionally been noted in discussions of state sovereign immunity, ${ }^{119}$ its significance to the men who framed the Constitution has largely been overlooked. Nathan was represented before the Pennsylvania court by none other than James Wilson, ${ }^{120}$ the great advocate of limited governmental sovereignty and the guiding force behind both the Pennsylvania constitutional provision that authorized suits against that state $^{121}$ and the Original Jurisdiction Clause of the Constitution. ${ }^{122}$ Among the Virginia delegates who signed communiques with the Pennsylvania Supreme Executive Council was James Madison. ${ }^{123}$ Letters from Thomas Jefferson, the sitting governor of Virginia at the time, reflect his interest in the case; ${ }^{124}$ he was at least sufficiently concerned to request of Edmund Pendleton, later a delegate to the Philadelphia Convention and the president

cases of the forum executive. The usual procedure for contesting litigation in violation of sovercign immunity was to lodge a complaint through diplomatic channels and to avoid any direct appearance in the litigation. A direct appearance was itself thought to violate the dignity of the sovercign and may have been construed, as it was by a federal district court judge in Ex parte Republic of Peru, 318 U.S. 578 (1943), as a waiver of the immunity defense. Id. at 581-82 (recounting that the district court found that petitioner had waived its immunity by applying for extension of time within which to answer and by taking the deposition of the master).

118. No wonder Dallas included the case in his reports with a note to the effect that it may "give some satisfaction to our sister states." Nathan, 1 U.S. (1 Dall.) at 77 n.(a). Similarly, when Georgia refused to appear before the Supreme Court in the Chisholm case, and sent a remonstrance instead, it was asscrting its sovereign immunity according to the established pattern.

119. See JACOBs, supra note 84, at 13; Fletcher, supra note 91, at 1074-78.

120. See Letter from Thomas Jefferson to Virginia Delegates (Mar. 15, 1781), in 3 ThB PAPERS op James MADison 20, 20 (William T. Hutchinson \& William M.E. Rachal eds., 1963) [hereinafter Madison Papers]; Freeman's J. (Philadelphia), Oct. 17, 1781, at 1 (letter to the printer protesting the inaccuracy of his account of Nathan $v$. Virginia, criticizing the court's decision, and identifying Wilson as having made the argument on behalf of Nathan).

121. James Wilson worked to secure a constitutional provision in Pennsylvania that effected a waiver of the state's immunity and authorized the legislature to establish a mechanism for the assertion of claims against the state. See JACOBS, supra note 84, at 25 \& n.53.

122. See infra note 245 and accompanying text.

123. See Letter from Virginia Delegates to Supreme Executive Council of Pennsylvania (circa July 9, 1781), in 3 MAdison PAPERS, supra note 120, at 184, 184-85; Letter from Virginia Delegates to Joseph Reed (July 13, 1781), in 3 MAdison PAPERS, supra note 120, at 191, 191.

124. See Letter from Thomas Jefferson to Edmund Randolph (July 18, 1783), in 6 THE PAPRRS of Thomas Jefrerson 319 (Julian P. Boyd ed., 1952) [hercinafter Jefrerson Papers] (providing recollections of Virginia's transactions with Nathan); Letter from Thomas Jefferson to George Rogers Clark (Mar. 19, 1780), in 3 Jefrerson PAPERS, supra, at 316, 317 (Julian P. Boyd ed., 1951) (asking, in view of drafts presented to Virginia by Nathan and others in an amount "more than we are able to pay," that Clark send a list of all bills, specifying "whether silver or paper dollars were intended, and if paper at what rate of depreciation."); Letter from Thomas Jefferson to John Todd (Mar. 19, 1780), in 3 JefFerson PAPERs, supra, at 319, 319-21 (saine subject as letter to Clark); Letter from Thomas Jefferson to Virginia Delegates, supra note 120 (discussing differences of opinion regarding rate of exchange for Virginia's obligation to Nathan). 
of the Virginia ratifying convention, his opinion of the case's merits. ${ }^{125}$ For all these men, ${ }^{126}$ the action presented important questions of first impression.

The disposition of Nathan in favor of law-of-nations immunity deserves to be viewed as a decisive rejection of state suability in the courts of other states. ${ }^{127}$ Though a state was free to provide judicial remedies against itself by abrogating its common law immunity, law-of-nations sovereign immunity applied with full force to actions brought against one state in the courts of another. The point has been a source of confusion and deserves close attention. Scholars have pointed out that Virginia had made provision for the assertion of claims against the state in its own courts; ${ }^{128}$ similar provision had been made by Georgia. ${ }^{129}$ But the availability of relief in the sovereign's own courts was in good measure irrelevant; the law of nations still barred suit in the courts of another sovereign. ${ }^{130}$

It thus appears that the framers of the Constitution considered sovereign immunity a substantial hurdle to securing state compliance with the plan of the convention. The law-of-nations immunity gained by the states when they shed their colonial status barred the courts of other sovereigns from entertaining actions against states, despite the general recognition in America that ultimate sovereignty resided in the people themselves. The rule of immunity prevailed, moreover, notwithstanding any provision the states themselves might make, either by law or constitution, for the assertion of claims in their own courts.

125. Letter from Thomas Jefferson to the Judges of the High Court of Chancery (Mar. 5, 1781), in 5 JeFrERSON PAPERS, supra note 124, at 61 (seeking advice on Virginia's obligation to Nathan); see also Letter from Thomas Jefferson to Edmund Randolph, supra note 124 (recalling that the issue before the court was whether Virginia was bound by acceptances for hard money written on Nathan's bills before word arrived indicating that depreciation should have been allowed).

126. Edmund Randolph, Virginia's attorney general at the time and later a member of the Committee of Detail in Philadelphia, was intimately familiar with Nathan's claim. Randolph represented the Commonwealth at the arbitration of Nathan's claims in Maryland. See 3 JourNals of THE Council of the STAte of Virginia 282 (Wilmer L. Hall ed., 1952) thereinafter Council JourNaLs] (proceedings of July 31, 1783) (providing for Attomey General's expenses to attend the arbitration in Maryland); id. at 298 (proceedings of Oct. 22, 1783) (recording letter from Attorney General regarding continuation of the arbitration to December); id. at 315 (proceedings of Dec. 11, 1783) (providing for Attorney General's and arbitrator's expenses). Randolph's discussion in the Virginia ratification debates of the judicial role in preserving national peace and harmony mentions the dispute with Nathan and the decision to arbitrate in Maryland to assure impartiality. See infra note 334.

127. Much the same result was reached in a Pennsylvania admiralty court decision from the same period. In Moitez v. The South Carolina, 17 F. Cas. 574 (Adm. 1781) (No. 9697), sailors on board a South Carolina warship instituted a libel action against the vessel for the recovery of wages due. While the report of the case does not set forth the court's reasoning, it does reflect the Pennsylvania court's determination that the vessel's ownership by a "sovereign independent state" required dismissal of the action. Id.

128. See, e.g., Massey, supra note 4, at 90, 96 (citing St. George Tucker).

129. See supra note 101.

130. As noted earlier, Virginia ultinuately chose to permit individuals to sue the state in Virginia courts but nonetheless opposed Nathan's institution of an action against the state in the courts of Pennsylvania. See supra notes 116-18 and accompanying text. 
We are now in a position to refine the two competing accounts of state sovereign immunity to obtain a clearer picture of the franiers' conception of sovereign immunity. The "profound shock" theorists correctly observe that the principle of immunity reigned at the tinie of the framing, notwithstanding the revisionists' claims that America did not fully accept the British notions of sovereign prerogative. But the "profound shock" theorists overstate the doctrine's immutability: some states had already abandoned full immumity, at least in their own courts, and political thinkers of the day urged a further relaxation of the doctrine. The revisionists err to the extent they fail to recognize that, even with the selective relaxation of the comnion law immunity by some states in their own courts, the law of nations erected a substantial barrier to the assertion of clainis against states in the courts of other sovereigns. ${ }^{131}$ Such a bar would have applied to litigation in the courts of the Union unless the plan of the convention effected a waiver of such immunity. As we shall see, the grant of Supreme Court original jurisdiction effectuates such a waiver.

\section{B. The Functional Significance of the Madisonian Compromise}

\section{The Judicial Negative on State Action}

No one who reads an account of the framing of the Constitution can doubt that the framers sought to create a nrore vigorous national government and to rein in what were viewed as the excesses of popular government in the states. ${ }^{132}$ The Articles of Confederation had been counted a failure because the federal government-a league of friendly, but independent, states-was too weak to carry out national objectives. ${ }^{133}$ States were thought to enjoy too much power and to wield it unwisely, passing tender laws that obstructed the collection of just debts, issuing paper money, obstructing commerce and trade, and refusing to obey the provisions of the Treaty of Peace with Great Britain. ${ }^{134}$

The solution to the problen1, as Madison observed, was to create a hybrid government, part national (or consolidated, in the words of the

131. See supra note 99.

132. My account of the framing focuses on one small but important element of Article IlI. For a broader view, see Max Farrand, The Framing of the Constrtution of the United States (1913); Merrill Jensen, The Making of the American Constitution (1964); Warren, supra note 83; Garry Wills, Explanning america: The Federalist (1981); Gordon S. Wood, The Creation op THE AMERICAN REPUBLIC: 1776-1787 (1969).

133. See WARREN, supra note 83, at 5-8; FARRAND, supra note 132, at 2-3, 44-52. But see JensEN, supra note 132, at 30-32 (suggesting that the framers were a conservative lot who opposed the radical commitment to democracy reflected in the Articles of Confederation); JENSEN, supra note 93 (same).

134. See FARRAND, supra note 132, at 46.47 (describing the inability of Congress under the Articles to secure state compliance with the Treaty of Peace with Great Britain); WARREN, supra note 83, at 6 (describing state tender laws, paper money laws, and commercial restrictions on imports from other states as a focus of the framers' concerns); Gibbons, supra note 84, at 1899-902 (emphasizing state noncompliance with the Treaty of 1783 as a "significant factor" suggesting the need for a stronger central government). 
day ${ }^{135}$ ) and part federal. ${ }^{136}$ The new government was to consist of a popularly elected legislature (rather than merely representatives of the states themselves), a more vigorous executive, and a national judiciary. ${ }^{137}$ The three branches of government were permitted to enact, execute, and enforce laws that operated directly upon the citizens themselves. For example, Congress was given the power to tax individuals, the executive was obliged to collect the taxes, and the judiciary was empowered to hear claims arising from disputes over taxation, in accordance with the notion that the powers of the judiciary were to be coextensive with those of the first two branches. ${ }^{138}$

The creation and division of national power left the framers to grapple with the questions of how best to restrict the powers of the states and how

135. On the choice between consolidation and confederation, see Wood, supra note 132, at 524-32.

136. Madison's classic discussion suggests that the government was national to the extent that it derived its powers from, and enjoyed authority to enforce laws against, the individual citizens of the nation; it was federal to the extent that its powers derived from, and acted upon, the states. See ThE Federalist No. 39, at 253-57 (James Madison) (Jacob E. Cooke ed., 1961). Under such a typology, Madison considered Article III to present something of a mixed bag. The judiciary clearly had authority to act on the people as individuals - a power that called for a national designation. But Madison also observed that Article III's provision for the exercise of original jurisdiction over disputes involving state parties gave the judiciary a partly federal character as well. Id. at 255 ("In several cases and particularly in the trial of controversies to which States may be parties, they must be viewed and proceeded against in their collective and political capacities only.").

137. Suspicious of unlimited government, or convinced of the difficulty of obtaining ratification of a govemment with unlimited powers, the framers also erected a complex system of limitations on national authority. For a useful summary, see Amar, supra note 82, at 1439-51. Congress was to be limited to designated powers; such limits were to be enforced by the executive, through the use of the vcto power, and the judiciary, through the adjudication of cases that tested legislation against the scope of constitutional authority. See generally Raoul Berger, Congress v. THE Supreme Court (1969) (collecting authority from the convention and the ratification debates that affirms the existence of a judicial negative on congressional power).

138. The doctrine of coextensivity, that the enforcement powers of the judiciary were coterminus with those of Congress to enact laws of the United States, played an important role in the political thinking of the day. As Hamilton explained, "If there are such things as political axioms, the propriety of the judicial power of a govemment being co-extensive with its legislative, may be ranked among the number." The Federalist No. 80, at 535 (Alexander Hamilton) (Jacob E. Cooke ed., 1961); see also 1 BLACKSTONE, supra note 89, app. at 419 (linking judicial power over cases arising under law of the United States to the subjects on which Congress enjoys legislative authority). On the implications of coextensivity, which figured prominently in such Marshall Court opinions as Martin v. Hunter's Lessee, 14 U.S. (1 Wheat.) 304, 329 (1816), and Cohens v. Virginia, 19 U.S. (6 Wheat.) 264, 384 (1821), see Amar, supra note 12, at 250-51 \& n.147 (noting that interpretation of laws by an impartial and independent judiciary would prevent retroactive niodification and ensure even-handed application). Although left unstated in such discussions, political thinkers regarded the executive power of the second branch as coextensive with the legislative and judicial powers of the first and third branches. See Osborn v. Bank of United States, 22 U.S. (9 Wheat.) 738, 818-19 (1824) ("[T] and judicial powers of every well-constructed governnient, are co-extensive . . . The executive department may constitutionally execute every law which the legislature may constitutionally make, and the judicial department may receive from the legislature the power of construing every such law. All governments which are not extremely defective in their organization, must possess, within theniselves, the means of expounding, as well as enforcing, their own laws."). 
best to enforce such restrictions. ${ }^{139}$ As Hamilton explained in the Federalist Papers, two methods of enforcing state compliance with federal law were considered. ${ }^{140}$ The first, a favorite of Madison, ${ }^{141}$ would have given Congress the right to veto state laws. Such a "congressional negative" had been made part of the Virginia plan, ${ }^{142}$ rejected in the first round of debates on the new government, ${ }^{143}$ and revived and defeated during consideration of the draft constitution. ${ }^{144}$ The second method of ensuring state compliance with federal law-the exercise of federal judicial power in litigated disputes-was seen by the framers as an alternative to the congressional negative; this "judicial negative" was the method that the convention finally adopted. ${ }^{145}$

139. Part of the solution lay simply in the creation of national institutions with the power to regulate individuals. To continue the earlier example, states could not well interfere with federal collection of taxes when the national government enjoyed legislative power to lay the taxes upon individuals, executive power to collect the taxes from individuals, and judicial power to punish individual interferences with such collection efforts, through both civil and eriminal sanctions. But the states retained vast areas of legislative authority that were not eeded to Congress, as well as general common law jurisdiction far broader than that of the federal courts. They could, for example, entertain state law trespass claims against federal officers, at least until Congress chose to authorize the removal of such state law claims to the federal courts.

140.

No man of sense will believe that such prohibitions [on state action] would be scrupulously regarded, without some effectual power in the government to restrain or correct the infraetions of them. This power must either be a direct negative on the state laws, or an authority in the federal courts, to over-rule such as might be in manifest contravention of the artieles of union.

The Federalist No. 80, at 535 (Alexander Hamilton) (Jacob E. Cooke ed., 1961); see Sager, supra note 78, at $52 \mathrm{n.} 103$ (reading Hamilton as referring to the congressional negative).

141. Consider Madison's remarks in favor of the congressional negative when it first came before the full convention:

Mr. <Madison, > considered the negative on the laws of the States as esscntial to the efficaey \& security of the Genl. Govt. The necessity of a general Govt. proceeds from the propensity of the States to pursue their particular interests in opposition to the gencral interest. This propensity will continue to disturb the system, unless effectually controulcd. Nothing short of a negative on their laws will controul it... Confidence can $<$ not $>$ be put in the State Tribunals as guardians of the National authority and interests. In all States these are more or less dependt. on the Legislatures.

2 ReCORDS OF THE FEDERAL CONVENTION, supra note 77, at 27-28.

142. The sixth article of the Virgimia plan provided that the "National Legislature ought to be impowered ... to negative all laws passed by the several States contravening in the opinion of the National Legislature the artieles of Union." See 1 DocumentaRY HISTORY OF THE CONSTTrutron, supra note 109, at 244 . The so-called Pinckney plan included a similar provision, barring any state law from taking effect absent congressional approval. See id. at 246.

143. The provision for congressional control of state action attracted the initial support of the Committee of the Whole, which voted on May 31 to give Congress authority to negative state laws that violated the Constitution or any treaty. See 1 RECORDS OF THE FEDERAL CONVENTION, supra note 77, at 47,54 . But on July 17 , the full convention rejected this means of control by a vote of 7-3. 2 id. at 2122, 27-28.

144. The congressional negative was resurrected and finally interred on August 27, during consideration of the federal judicial power. See infra notcs 268-70 and accompanying text.

145. Hamilton's remarks make clear that the framers viewed the judicial negative as an alternative to legislative control of the states. This also seems apparent on the face of the convention's records. Thus, immediately after rejecting the congressional negative on July 17 , the convention voted unanimously to approve the precursor of the Supremacy Clause. See 2 ReCords of the FedrRal CONVENTION, supra note 77, at 22, 28-29. Opponents of the congressional negative had anticipated this 
In drafting the Constitution, the framers created a mechanism for judicial control of state action. First, immediately after rejecting the congressional negative, the framers adopted the precursor to the Supremacy Clause. ${ }^{146}$ A similar clause had been included in the Articles of Confederation ${ }^{147}$ but had been rendered ineffective by the absence of any mechanism to enforce state court comphance with national law. Mindful of this failure of the Articles, the framers also created a national judicial branch to secure enforcement of state compliance with federal law. The opening lines of Article $\mathrm{II}^{\mathbf{1 4 8}}$ reflected widespread agreement among the delegates that the new government required an independent federal judicial branch that would enjoy, at a minimum, the power to review state court decisions in matters affecting the national interest. ${ }^{149}$ The framers sought to guarantee this power by vesting the Supreme Court-the only court mandated by Article III-with a constitutional source of jurisdiction to review state court decisions on matters of federal law. ${ }^{150}$ The framers achieved this goal in the jurisdictional menu, ${ }^{151}$ which extends the judicial power to "all Cases" arising under the Constitution, laws, and treaties of the United

development by urging the availability of judicial control as an alternative to the legislative veto. See id. at 28 (remarks of Governor Morris). For a comprehensive account, see WARREN, supra note 83, at 31624; Amar, supra note 12, at 223 n.69, 224-26 (discussing various proposals for control of state legislation and the framers' ultimate adoption of judicial control).

146. The clause declares the Constitution, laws, and treaties of the United States to be the supreme law of the land and makes them binding on state judges, notwithstanding anything to the contrary in the Constitution or laws of the states. See U.S. CoNST. art. VI, cl. 2. The text of the version of the Supremacy Clause adopted by the Convention on July 17 declared only the "Legislative acts" and "treaties" of the United States the supreme law of the several states, binding on state judges notwithstanding state law. See 2 Records of THE FEDERAL Convention, supra note 77, at 28-29. The Committee of Detail reworked this language somewhat but still omitted the Constitution itself from the clause's description of supreme texts. See id. at 183. It was not until August 23 that the convention finally completed the judicial negative by adding the Constitution to the terms of the Supremacy Clause. See id. at 381-82, 389.

147. Article XIII provided that "[e]very state shall abide by the determinations of the united states in congress assembled, on all questions which by this confederation are submitted to them." 1 Documentary History of THE Constitution, supra note 109, at 93.

148. Article III, Section 1 declares that the "judicial Power of the United States, shall be vested in one supreme Court, and in such inferior Courts as the Congress may from time to time ordain and establish." U.S. ConsT. art. III, § 1 .

149. See FARRAND, supra note 132, at 79 ("That there should be a national judiciary was readily accepted by all."). Even those who opposed the creation of lower federal courts and argued for the original resolution of judicial business in the state courts appeared to admit the necessity of authorizing the Supreme Court to exercise appellate review. Thus, in urging the deletion of the provision for lower federal courts that produced the Madisonian coinpromise, Rutledge urged that state tribunals were competent to "decide in the first instance the right of appeal to the supreme national tribunal being sufficient to secure the national rights \& uniformity of Judgmts." 1 RECORDS OF THE FEDERAL Convention, supra note 77, at 124.

150. As Professor Sager notes, "it is now well settled that Article III itself contains a direct, selfexecuting grant of jurisdiction, both appellate and original, to the Supreme Court." Sager, supra note 78, at 23-24; see also Robert N. Clinton, A Mandatory View of Federal Court Jurisdiction: Early Implementation of and Departures from the Constitutional Plan, 86 ColvM. L. REv. 1515, 1576-89 (1986) (discussing Durousseau v. United States, 10 U.S. (6 Cranch) 307, 313-14 (1810)).

15I. See supra note 13 and accompanying text. 
States-language that resembles the provisions of the Supremacy Clause. ${ }^{152}$ Following the extension of judicial power to all federal question cases, Section 2, the "Distribution Clause,"153 declares that the Court shall have appellate jurisdiction in all federal question cases, other than those assigned to the Court's original docket. ${ }^{154}$

\section{The Madisonian Compromise and the Functional Significance of the Court's Original Jurisdiction}

The adoption of this scheme of judicial control of the states incorporated the famed Madisonian compromise, which the Convention adopted on July 18 , one day after rejecting the congressional negative in favor of judicial control. ${ }^{155}$ The compromise empowered but did not require the national legislature to create tribunals inferior to the Supreme Court. As it relates to the Court's exercise of appellate jurisdiction, the lessons of the Madisonian compromise have been well rehearsed and can be briefly summarized. The Distribution Clause confers appellate jurisdiction on the Supreme Court in "all other Cases before mentioned ... with such Exceptions, and under such Regulations as the Congress shall make." 156 The

152. For the text of Article III, $\S 2$, see infra text accompanying note 175 .

153. Use of the term "Distribution Clause" to describe the clause that confers original and appellate jurisdiction on the Supreme Court dates from the early days of the Republic. Hamilton, for example, introduced bis discussion of the clause as an examination into the manner in which "the judicial authority is to be distributed between the supreme and the inferior courts of the union." THE Federalist No. 81, at 548 (Alexander Hamilton) (Jacob E. Cooke ed., 1961); see also Chisholm v. Georgia, 2 U.S. (2 Dall.) 419, 451 (1793) (Blair, J.) (noting that the Constitution speaks of judicial powers "distributively").

154. For the text of the Distribution Clause, see infra text accompanying note 176.

155. See 2 Records of the Federal Convention, supra note 77 , at $38,45-46$. The debates, which focused on the competence of the state courts to handle federal business in the first instancc, have been summarized in WARREN, supra note 83 , at 325-27.

156. Congress does not often act as though the Supreme Court rcceives its jurisdiction directly from the Distribution Clause. Instead, Congress affirmatively vests the Court with original and appellate jurisdiction, and has done so ever since it adopted the Judiciary Act of 1789. The Court, though, treats the omissions from its appellate jurisdiction as implicit subtractions from the Constitutional grant, subtractions authorized by the Exceptions and Regulations Clause. See Durousseau v. United States, 10 U.S. (6 Cranch) 307, 313 (1810). The constitutional basis of the Court's jurisdiction remains important, as Professor Sager and others have emphasized, because it permits the Court to strike down unconstitutional limitations on its jurisdiction and proceed under the terms of the constitutional grant. See Sager, supra note 78, at 25; see also Amar, supra note 12, at 229-30 (arguing that in exereising its power to make exceptions to the Court's appellate jurisdiction, Congress must create lower federal courts to hear sucb appeals, since exceptions to the Court's appellate jurisdiction may violate the Constitution if they deny the federal judiciary the last word in all cases that present federal questions).

The power of Congress to fashion exceptions to the Court's appellate jurisdiction has formed the subjeet of an immense literature. In addition to the contributions of Sager and Amar, see, for example, Robert N. Clinton, A Mandatory View of Federal Court Jurisdiction: A Guided Quest for the Original Understanding of Article III, 132 U. PA. L. Rev. 741 (1984); Henry M. Hart, Jr., The Power of Congress to Limit the Jurisdiction of the Federal Courts, 66 HARv. L. REv. 1362 (1953); Leonard G. Ratner, Congressional Power over the Appellate Jurisdiction of the Supreme Court, 109 U. PA. L. REv. 157 (1960); Martin H. Redish, Constitutional Limitations on Congressional Power to Control Federal Jurisdiction: A Reaction to Professor Sager, 77 Nw. U. L. REv. 143 (1982). 
Supreme Court has long held that this grant of constitutional power enables it to review on appeal final state court decisions that implicate the Constitution, laws, and treaties of the United States. As Justice Story explained in the leading case, Martin v. Hunter's Lessee, ${ }^{157}$ the framers certainly contemplated that cases presenting federal questions might originate in the state courts as a result of the Madisonian compromise. ${ }^{158}$ The grant of appellate jurisdiction must therefore have contemplated the possibility of Supreme Court appellate review of all such state decisions, at least to the extent that they implicated federal law. ${ }^{159}$

The Madisonian compromise yields equally important, but largely ignored, insights into the functional significance of the grant of original jurisdiction over state-party cases. Consider the difficulty confronting the framers who sought to provide a secure foundation for actions to compel the states to comply with supreme federal law. It is true that the Supreme Court enjoyed appellate jurisdiction over cases involving state parties, at least insofar as the case presented a federal question: such was the explicit holding of the Court in Cohens v. Virginia. ${ }^{160}$ But the availability of appellate review in cases that presented federal questions did not necessarily ensure the effective assertion of federal rights against the states. In order for the Court to assert appellate jurisdiction, there had to be an original tribunal where the claim was brought. The framers, however, could not depend on the existence of an original docket for coercive claims against a state. The Madisonian compromise left the decision whether to establisl lower federal courts in the hands of Congress, thus leaving open the possibility there might be no inferior courts. ${ }^{161}$ Even if it chose to create inferior

I find the work of Professors Sager and Amar persuasive and lean toward a reading of the Exceptions Clause as limited by the menu's requirement that the judicial power extend to all "cases." On such a reading, Congress can fashion exceptions to the Court's appellate docket but may not leave state courts as the ultimate decision-makers in federal question, admiralty, and ambassador "cases." Indeed, as I point out later, my proposed reading of the Original Jurisdiction Clause would appear to perfect Amar's two-tier thesis by assuring a federal forum for an important class of federal question claims-those against state defendants-that might otherwise evade federal judicial resolution.

I do not wish to debate the meaning of the Exceptions Clause, however. When I speak in the text about the Court's power of appellate review under the Distribution Clause, I do so on the assumption that the Constitution vests the Court with an initial grant of appellate jurisdiction. While Congress has some (perhaps limited) power to depart from such a grant under the Exceptions Clause, I am principally concerned with the scope of the initial grant, the rationale for the initial grant, and the insights such a grant offers into the function of original jurisdiction.

157. 14 U.S. (1 Wheat.) 304 (I8I6).

158. Martin v. Hunter's Lessee, 14 U.S. (1 Wheat.) at 342; see also The Federalist No. 82, at 554-56 (Alexander Hamilton) (Jacob E. Cooke ed., I961) (arguing that state courts would retain concurrent jurisdiction of all matters previously cognizable in state courts, subject to an appeal to the Supreme Court).

159. Justice Story also pointed out that the existence of such federal appellate authority had been universally admitted during the ratification debates and exercised without question by the Court for years before Virginia's objection. See Martin v. Hunter's Lessee, 14 U.S. (1 Wheat.) at 351-52.

160. 19 U.S. (6 Wheat.) $264,391-92$ (1821).

161. The prospect that Congress would refrain from establishing lower federal courts was not purely hypothetical. Many comments in the ratification debates assumed that although Congress would 
courts, Congress - particularly the upper chamber, which was understood to represent the states most directly ${ }^{162}$-might refrain from authorizing them to hear original suits against the states. Meanwhile, the courts of states other than that sued would presumably recognize law-of-nations immunity and therefore dismiss such claims against equal and independent sovereigns, just as the Pennsylvania court had done in Nathan $v$. Virginia. ${ }^{163}$ At the same time, the courts of the particular state would presumably invoke their common law immunity as a bar to any suit against the state. Even where the state legislature had abrogated their common law immunity by creating a remedy agamst the state, state courts, as well as the legislature, might well adopt narrowing interpretations and restrictive amendments that would complicate the effective assertion of federal claims. ${ }^{164}$

In the absence of any assured forum for the original assertion of coercive claims against the states, the framers could not rely on the appellate power of the Supreme Court to assure state compliance with federal law. ${ }^{165}$ One might speculate that the framers could have resolved this problem by compelling the states to entertain federal claims against themselves. Indeed, modern decisions of the Court suggest limitations on the power of the states to refuse to entertain federal claims, at least in the absence of a valid excuse. ${ }^{166}$ Perhaps the most far-reaching of those decisions, General

do well to institute inferior courts of admiralty, it might leave other federal matters to the state courts. See 3 Ellot's DeBates, supra note 50, at 517 (remarks of Edmund Pendleton) ("I think it highly probable that their first experiment will be, to appoint the state courts to have the inferior federal jurisdiction . . . ."); id. at 660 (proposing amendment to limit federal judiciary to Supreme Court and inferior federal courts of admiralty); Clinton, supra note 156, at 816 (stating that, since the Constitution did not require Congress to create inferior federal courts, the only way to ensure that state courts were not left with exclusive jurisdiction over federal questions was to vest appellate jurisdiction in the Supreme Court).

162. The plan of the convention called for the state legislatures to appoint Senators to the upper chamber for six-year terms. See U.S. ConsT. art. 1, \$3. Because each state enjoyed two votes in the Senate, the framers regarded the Senate as the representative of the interests of the small states; in contrast, the Constitution called for direct popular elections of members of the House and apportionment of representation according to population. See U.S. ConST. art. 1, \& 2. Many debates over the locus of power, such as the power of appointing judges and ratifying treaties, turned on the delegates' recognition that the states would exercise greater control in the Senate. See 2 Records of THE Federal Convention, supra note 77, at 392 (recounting that Madison opposed power of the Senate to make treaties on the ground that "the Senate represented the States alone"); Amar, supra note 12, at 250 n.146 (discussing mode of judicial selection); Sager, supra note 78, at 47 (describing debate over power of judicial appointment).

163. 1 U.S. (1 Dall.) 77 n.(a) (Pa. C.P. 1781).

164. On the framers' distrust of state judges, see Madison's comments, supra note 141; Amar, supra note 12, at 235-38; Clinton, supra note 156, at 815-16.

165. The appellate power was adequate to the task whenever a federal-question claim was allowcd to go forward in the state courts in the first instance. Thus, the Court invoked its appellate power in Cohens v. Virginia, 19 U.S. (6 Wheat.) 264 (1821), notwithstanding the fact that the state itself appeared as a party in the litigation. However, the Commonwealth of Virginia had itself initiated the proceeding as an enforcement action in its own courts; it is far from clear that the Virginia courts would have agreed to hear a coereive constitutional claim brought against the state by the Cohens.

166. See Testa v. Katt, 330 U.S. 386, 389 (1947) (holding that state courts may not refuse to entertain federal action for treble damages on the ground that such actions were "penal" in the 
Oil Co. v. Crain, ${ }^{167}$ holds that the Court's appellate jurisdiction extends to state court decisions refusing to assert jurisdiction over federal claims on grounds of sovereign immunity. ${ }^{168}$ Decisions such as Crain suggest that the states owe a positive duty to entertain at least some federal claims against themselves, regardless of their own jurisdictional and immunity limits; in any event, their decision to refrain from doing so does not constitute a state ground adequate to bar appellate review.

Whatever the current vitality of Crain, ${ }^{169}$ a decision that was no doubt driven in part by concerns about the Eleventh Amendment, ${ }^{170}$ its rationale

international sense, especially where state agreed to hear similar kinds of penal proceedings); McKnett v. St. Louis \& S.F. Ry., 292 U.S. 230, 233-34 (1934) (states may not "discriminate against rights arising under federal laws"); Second Employers' Liability Cases, 223 U.S. 1, $57-58$ (1912) (holding that state courts must entertain FELA action; disagreement with federal policy expressed in the Act not a valid excuse); $c f$. Douglas v. New York, N.H. \& H.R.R., 279 U.S. 377, 387-88 (1929) (holding that a federal statute does not compel state cognizance of proceeding where state proffers a valid "inconvenient forum" excuse).

167. 209 U.S. 211 (1908).

168. See id. at 226. The action in Crain was brought in state court to secure an injunction against the enforcement of a state tax on both state and federal grounds. The Tennessee Supreme Court held that its courts lacked jurisdiction over such claims on sovereign immunity grounds. The State argued that such a disposition was an adequate and independent ground that barred appellate review. Although the Court sustained the tax on the merits, it held that it enjoyed jurisdiction to review the state decision. It expressed concern that the Eleventh Amendinent, when coupled with state court invocations of sovereign inmunity, would deprive the Court of jurisdiction-thereby providing an "easy way ... to prevent the enforcement of inany provisions of the Constitution." Id. Justice Harlan was not persuaded. See id. at 233 (Harlan, J., concurring) ("Tennessee has the right to say of what class of suits its own courts may take cognizance, and it was peculiarly the function of the Suprene Court of Tennessee to determine such a question.").

169. The clearest explication of the view rejected in Crain appears in Justice Frankfurter's concurring opinion in Brown v. Gerdes, 321 U.S. 178, 188 (1944):

Neither Congress nor the British Parliament nor the Vermont Legislature has power to confer jurisdiction upon the New York courts. But the jurisdiction conferred upon them by the only authority that has power to create then ... . - namely the law-making power of the State of New York-enables them to enforce rights no matter what the legislative source of the right may be.

Similarly, in Georgia R.R. \& Banking Co. v. Musgrove, 335 U.S. 900 (1948) (per curiam), the Court upheld the state court's refusal to entertain a Contract Clause claim. The Court accepted the state supreme court's reasoning that the state's invocation of immunity was an adequate state ground barring review. But see Hopkins v. Clemson Agric. College, 221 U.S. 636, 649 (1911) (reviewing and reversing state court's conclusion that sovereign immunity barred federal suit).

170. See supra note 168 . Scholars today disagree as to whether the state courts owe a positive duty to entertain federal claims against the state. Compare Nicole A. Gordon \& Douglas Gross, Justiciability of Federal Claims in State Court, 59 Notre DAME L. Rev. 1145, 1151, 1156-77 (1984) (asserting that state courts inust entertain federal clains without regard to state sovereign immunity) and Louis $\mathrm{E}$. Wolcher, Sovereign Immunity and the Supremacy Clause: Damages Against States in their Own Courts for Constitutional Violations, 69 CALIF. L. REv. 189, 303-04 (1981) (same) with HART \& WECHSLER, supra note 10 , at 587-88 (raising possibility that the existence of state court obligation may depend on the availability of alternative remedies). Professor Vicki Jackson cogently points out the disparity betwcen the scope of state Eleventh Amendment immnnity from suit in the lower federal courts and that on appeal from state courts to the Supreme Court, see Jackson, supra note 91, at 13-15; after rejecting alternative rationalizations, $i d$. at $32-39$, she ultimately concludes that the best resolution of the disparity lies in adopting a "diversity" theory of the Eleventh Amendinent applicable both originally and on appeal and in developing a federal common law of immunity for states in other circumstances. See id. at $32-39,104-26$. 
was unlikely to have appealed to the framers as the best way to fill the remedial gap created by the dual doctrines of sovereign immunity. The framers may well have assumed that the federal system would simply take the state courts as it found them; state courts could exercise a concurrent jurisdiction over any federal claims that fit comfortably within their preexisting jurisdiction-what Hamilton in The Federalist called their primitive jurisdiction ${ }^{171}$ - so long as the federal claims were not, by virtue of congressional decree, subject to the exclusive jurisdiction of the federal courts. ${ }^{172}$ It seems unlikely, however, that the framers would have chosen to compel the state courts to entertain federal claims against their will and in violation of their own jurisdictional limits. ${ }^{173}$ Such an approach would

I do not wish to enter the debate over the implications of the Eleventh Amendment for the obligation of states to entertain federal actions. I simply wish to make the point that the framers dealt with this problem by establishing a mandatory original tribunal for the assertion of original elaims against the states and so closed the remedial gap created by the doctrine of state sovereign immunity. For the framers, the existence of federal courts lessened the need to compel state courts to entertain federal claims. The Eleventh Amendment reopens that gap to one degree or another, and thus makes the disparity in treatment identified by Professor Jaekson quite real.

171. See The Federalist No. 82, at 555 (Alexander Hamilton) (Jaeob E. Cooke ed., 1961).

172. In his discussion of the states' power to exercise concurrent jurisdiction with the federal courts over federal cases, Hamilton had this to say:

I mean not therefore to contend that the United States in the course of legislation upon the objects entrusted to their direction may not commit the deeision of causes arising upon a particular regulation to the federal courts solely, if such a measure should be deemed expedient; but I hold that the state courts will be divested of no part of their primitive jurisdiction, further than may relate to an appeal; and I am even of opinion, that in every case in which they were not expressly excluded by the future acts of the national legislature, they will of course take cognizance of the causes to whieh those acts may give birth. . . . The judiciary power of every government looks beyond its own local or municipal laws, and in civil cases lays hold of all subjects of litigation between parties within its jurisdietion . . . . Id. at 555. Hamilton thus assumed that the state courts would assert concurrent jurisdietion over federal claims, at least in all civil proceedings. What he thought about the power of state courts to hear claims of a federal penal or criminal nature he did not say expressly, though his careful referenee to eivil cascs suggests he was aware that criminal matters presented a different question.

173. Evidence from the post-ratification debate on the enforcement of transitory penal claims offers some support for the proposition that the Constitution was not thought to compel state courts to entertain federal claims. On one side of this debate were those, like Justice Story, who believed that state courts were incompetent to hear federal clainis of a penal or criminal nature. See Martin v. Hunter's Lessec, 14 U.S. (1 Wheat.) 304, 337 (1816) (Story, J.) ("No part of the criminal jurisdiction of the United States can, consistently with the constitution, be delegated to state tribunals."); 3 JosEpH STORY, Commentaries on the Constrtumon of the United States 622-23 (1833); $c$. Houston v. Moore, 18 U.S. (5 Wheat.) 1, 68-69 (1820) (Story, J., dissenting) (arguing that a state court may not assume jurisdiction over a federal offense that federal courts do not have jurisdiction over). But see id. at 28-29 (Washington, J.) (upholding power of state court to try serviceman for violation of federal military law). Story was joined, some time later, by state court judges who invoked the doctrine as a basis for closing their doors to certain kinds of federal claims. See 1 KENT, supra note 41, at 448-51. On the other side of the debate stands Professor Charles Warren, who has shown not only that early Congresses frequently authorized state courts to hear such claims but also that early state courts did so without objections. Warren thus criticizes both state and federal decisions that treat federal penal claims as inherently beyond the reach of state court competence. See Charles Warren, Federal Criminal Laws and the State Courts, 38 HARv. L. Rev. 545, 553-54 (1925); see also Amar, supra note 12, at 213-14 (stating that state court cognizanee of federal criminal matters is simply a recognition of the coneurrent general jurisdiction doctrine); Note, Utilization of State Courts to Enforce Federal Penal and Criminal Statutes: Development in Judicial Federalism, 60 HARV. L. Rev. 966, 969 (1947). 
have been extremely cumbersome, instructing state courts to hear suits against the state and then requiring the courts to submit their disposition of the claim to federal appellate review. ${ }^{174}$

In sum, the dual doctrines of state sovereign immunity, coupled with the Madisonian compromise, confronted the framers with a remedial gap in their plan to compel state compliance with supreme federal law. The Constitution's provision for the Court's exercise of appellate jurisdiction over all federal cases could not operate effectively unless an original tribunal would hear coercive claims against the states in the first instance. But the framers could not count on the existence of a lower federal tribunal and the doctrine of sovereign immunity foreclosed any reliance on state courts; moreover, the framers were unwilling to compel state courts to hear federal claims. The far simpler solution, the one adopted by the framers, was to vest the only federal court that Congress was obliged to create, the Supreme Court, with a constitutional source of original jurisdiction over claims against the states.

I consider the debate over the enforcement of penal claims below in the context of evidence from the ratification era. See infra notes 216-17. For now, I simply wish to note that neither side in the debate identified by Professor Warren believed that the federal govemment had the power to compel the state courts to hear federal claims. See Warren, supra, at 583-84 ("So far as the decisions [that claim that it was inherently impossible for the state courts to exercise federal powers, even if Congress should grant them and the states be willing to exercise them] were based on the ground that nothing in the Constitution gives Congress the right to impose duties on the State Courts, these decisions were undoubtedly well founded."); see also James D. Barnett, The Delegation of Federal Jurisdiction to State Courts, in 3 Selected Essays in Constrtumonal Law 1202, 1213 (Association of Am. Law Sch. ed., 1938) ("TT]he courts have invariably held, either without argument, because apparently the matter is too clear for argument, or upon the expressly stated ground of the independent position of the States, that the exercise of [congressionally delegated] jurisdiction in such cases is wholly optional with the State authorities."); $3 \mathrm{KENT}$, supra note 41 , at 451 ("The doctrine secms to be admitted, that Congress cannot compel a state court to entertain jurisdiction in any case.").

More recent decisions, to be sure, hold that state courts may owe a positive duty to entertain federal claims, even those that Justice Story and Professor Warren would have considered penal. See Testa v. Katt, 330 U.S. 386 (1947); supra note 166. This obligation may well extend to federal law claims against the state itself. See supra note 168 . Yet the driving force behind the imposition of this obligation on the states-the broad and arguably ahistorical reading of the Eleventh Amendment's bar to the assertion of federal jurisdiction over such claims, see supra note 88-would not have informed the framers' conception of the best way to close the remedial gap opened by the doctrine of state sovereign immunity.

174. Professor Sandalow makes a similar argument in his well-known piece on the adequacy of state grounds:

[Testa and Mondou suggest] that the Constitution, presumably through the Supremacy

Clause, directly imposes upon the states an obligation to enforce federal claims that Congress has not committed to the exclusive jurisdiction of the federal courts. Yet it is difficult to perceive the federal interest that justifies so substantial an intrusion upon the power of the states to determine the purposes to be served by agencies of state government.

Sandalow, supra note 58 , at 206. 


\section{III \\ Taking "Cases" and "Controversies" Seriously: Rereading ARTICLE III}

The judicial Power shall extend to all Cases, in Law and Equity, arising under this Constitution, the Laws of the United States, and Treaties made, or which shall be made, under their Authority; - to all Cases affecting Ambassadors, other public Ministers and Consuls; - to all Cases of admiralty and maritime Jurisdiction;- to Controversies to which the United States shall be a Party;- to Controversies between two or more States;-between a State and Citizens of another State; - between Citizens of different States;--between Citizens of the same State claiming Lands under Grants of different States, and between a State, or the Citizens thereof, and foreign States, Citizens or Subjects.

In all Cases affecting Ambassadors, other public Ministers and Consuls, and those in which a State shall be Party, the supreme Court shall have original Jurisdiction. In all the other Cases before mentioned, the supreme Court shall have appellate Jurisdiction, both as to Law and Fact, with such Exceptions, and under such Regulations as the Congress shall make. ${ }^{175}$

The text of the Original Jurisdiction Clause provides a relatively straightforward answer to the question whether states were to enjoy law-ofnations sovereign immunity in the courts of the United States. It declares that "[i]n all Cases affecting Ambassadors, other public Ministers and Consuls, and those in which a State shall be Party, the supreme Court shall have original Jurisdiction." 176 By using the term "party," the framers evidently intended to extend the Court's jurisdiction both to claims brought by the states and to claims brought against them. ${ }^{177} \mathrm{By}$ framing the grant in mandatory terms, moreover, the framers constitutionally guaranteed the existence of a federal docket on which parties were authorized to assert claims against the states.

The Original Jurisdiction Clause thus answers the question whether states were subject as defendants to the jurisdiction of federal courts. It also describes the scope of such jurisdiction, authorizing the Court to hear "all Cases" in which states appear as parties ${ }^{178}$ - a reference to the "cases"

175. U.S. CoNsT. art. III, $\$ 2$, cls. $1,2$.

176. Id. cl. 2.

177. Thus, the argument of Edmund Randolph and the opinions of the Justices in Chisholm v. Georgia, 2 U.S. (2 Dall.) 419 (1793), place a good deal of emphasis on the Original Jurisdietion Clause's reference to state "parties." See id. at 420-21 (argument of Randolph); id. at 450-51 (Blair, J.); id. at 477 (Jay, C.J.). As Jay observes, had the framers intended to confine the jurisdiction to suits brought by states as plaintiffs, "it would have been easy to have found words to express it." Id. at 477.

178. See, e.g., Wyoming v. Oklahoma, 112 S. Ct. 789, 796 (1992) (declaring that the Constitution "provides this Court with original jurisdiction in all cases 'in whieh a State shall be a Party.' "); Ohio v. Wyandotte Chem. Corp., 401 U.S. 493, 495 (1971) ("Section 2, cl. 2, [of Article III] provides: 'In all 
listed in Section 2's jurisdictional menu. ${ }^{179}$ In this Section, I contend that the "all Cases" reference in the Original Jurisdiction Clause incorporates not only the "controversies" in which states appear as parties but also the "cases" that the menu describes as such. States were thus subject to jurisdiction in the "cases" that directly implicate the Constitution, laws, and treaties of the United States, as well as the diverse-party, non-federal "controversies" that turn on local or common law.

While this broad grant of jurisdiction abrogated the states' law-ofnations immunity from suit in federal court, it did not necessarily vitiate the states' common law immunity. I suggest that this second immunity question turns in part on the framers' important distinction between "cases" and "controversies." In the absence of some controlling federal law, as in nonfederal "controversies," federal courts could not justifiably ignore the states' established common law immumity or recognize the existence of a right of action against them. But where federal law imposed limits on state action, as in "cases" arising under the Constitution, the Supremacy Clause required federal courts to ignore any common law immumity and give effect to the law of the land. I contend, in short, that the grant of original jurisdiction trumped the states' law-of-nations immumity. Though it left the states' common law immunity intact, the latter immunity was forced to yield to the paramount authority of the Supremacy Clause in cases that implicate federal law restrictions on the freedom of the states.

Cases . . . in which a State shall be Party, the supreme Court shall have original Jurisdiction.' "); United States v. Texas, 143 U.S. 621 , 643 (1892) (paraphrasing Article III as grant of original jurisdiction "in all cases" in which a state shall be a party).

Professor Amar takes issue with the phrasing of the Court's original jurisdiction in Wyandotte Chemicals, arguing that the term "those" refers to "cases," not to "all cases," as Justice Harlan suggests. See Amar, supra note 12, at 254 n.160. Amar does not cite any authority for his claim, aside from his understanding that the Original Jurisdiction Clause encompasses only permissive-tier "controversies" and that, accordingly, the framers must have meant to omit the "all" to preserve the linguistic consistency of Article III's distinction between mandatory-tier "cases" and permissive-tier "controversies." For a discussion of Amar's theory, see supra notes 220-22. I will suggest, contra Amar, that the Harlans got it right in Wyandotte and United States $v$. Texas and that the reference to "all cases" reflects the framers' perception that mandatory-tier federal questions were included. See infra note 225 .

179. The claim that we must define "all cases" in which a state shall be a party by reference to the jurisdictional menu follows from the recognition that the menu defines the outer limits of federal judicial power. The subsequent provision for the Court's original and appellate jurisdiction does not augment the sources of federal judicial power; it merely operates to confer jurisdiction on the Court to hear certain of the matters previously described. Thus, for example, no one would read the Original Jurisdiction Clause as embracing a state's criminal prosecution of its own citizens; the menu does not embrace disputes between a state and its own citizens on matters of state law. Cf. Amar, supra note 10, at 488-89 (rejecting literal reading in part because it "autistically" broadens judicial power).

The text of the Distribution Clause offers support for the claim that it was drafted with the language of the menu in mind. The Ambassador Clause tracks the language of the jurisdictional menu word for word, in keeping with the framers' assumption that the grant of original jurisdiction acted on the sources of federal judicial power previously enumerated. Moreover, the Appellate Jurisdiction Clause confers appellate jurisdiction "in all other Cases before mentioned," language that evidently sweeps in all cases "before mentioned" on the jurisdictional menu that do not come within the Court's original jurisdiction. 


\section{A. Original Jurisdiction Over State-Party "Cases": Lessons from the Text and Leading Interpretations of Article III}

Our consideration of the text begins with the judicial power over "cases," the first and most important class of federal jurisdiction. I suggest that the Original Jurisdiction Clause's reference to state-party "cases" literally embraces all federal question "cases," as well as "cases" of admiralty and maritime jurisdiction in which states appear as parties. It thus authorizes the Court to hear claims against the state to remedy violations of the Constitution, laws, and treaties of the United States, and to adjudicate claims involving the states that arise in admiralty or maritime proceedings.

Note that what I have described as a literal interpretation of the Original Jurisdiction Clause, one that reads "cases" to mean "cases," does not expand the Court's jurisdiction beyond the subjects of federal cognizance identified in Article III. The State-party Clause does not embrace "all Cases" in the abstract but only "all Cases" that the menu defines as such. ${ }^{180}$ The Court's original jurisdiction thus includes a subset of federal question and admiralty "cases"- a subset limited to all such "cases" in which a state appears as a party. ${ }^{181}$ For this subset of state-party cases, after all, the Court's appellate jurisdiction was inadequate given the dilemma posed by the conjunction between state sovereign immunity and the Madisonian compromise.

The proposed federal-question-and-admiralty reading of the Court's original jurisdiction not only follows literally from the text of Article III, it also comports with the framers' expectation that the states would appear as defendants in the menu's federal question and admiralty "cases." In the "Arising Under" Clause, the framers evidently contemplated that the federal courts were to entertain actions against the states to enforce the restrictions on state authority embodied in Article I, Section $10^{182}$ and Article IV of the Constitution. ${ }^{183}$ Such was the direct implication of the comments of

180. See infra text accompanying notes $240-42$.

181. Nor does the proposed reading present any problem of ambiguity in defining the scope of the Court's original jurisdiction. The menu defines only three categories of jurisdiction over "cases": federal question cases, envoy cases, and admiralty and maritime cases. The Original Jurisdiction Clause authorizes the Court to hear all ambassador cases and all state-party cases. It thus assigns the entire ambassador head of jurisdiction to the Court's original docket-an assignment broad enough to encompass all claims affecting ambassadors in which states appear as partics. The subscquent grant of original jurisdiction in state-party cases goes further, extending the Court's original jurisdiction to all state-party cases. It thus makes clear that the Court may hear all state-party "cases" originally, whether those cases present federal questions, affect ambassadors, or fall within admiralty and maritime jurisdiction.

182. Article $\mathrm{I}, \S 10$ imposes the following limitations on the power of the states: barring them from emitting bills of credit, coining money, enacting laws that make paper money a valid tender in payment of debts, impairing the obligation of contracts, and entering into compacts or alliances with foreign states.

183. Sections one and two of Article IV impose additional obligations on the states, requiring them to give full faith and credit to the laws and judicial proceedings of other states, to respect the privileges and immunities of the citizens of other states, and to extradite fugitives from justice. 
Alexander Hamilton in The Federalist No. 80, adverting to the framers' choice of the judiciary, rather than a congressional negative, as the principal federal check on state excesses:

The states, by the plan of the convention are prohibited from doing a variety of things; some of which are incompatible with the interests of the union, and others with the principles of good government. The imposition of duties on imported articles, and the emission of paper money, are specimens of each kind. No man of sense will believe that such prohibitions would be scrupulously regarded, without some effectual power in the government to restrain or correct the infractions of them. This power must either be a direct negative on the state laws, or an authority in the federal courts, to over-rule such as might be in manifest contravention of the articles of union. . . . The latter appears to have been thought by the convention preferable to the former, and I presume will be most agreeable to the states. ${ }^{184}$

Hamilton presumed that the federal courts, by virtue of their authority to hear "cases" in law and equity, would enjoy the power to "restrain" or enjoin state infractions of the Constitution and to "correct" such infractions in appropriate cases by awarding damages against the state. ${ }^{185}$

Madison echoed this comment in the Virginia ratifying debates, responding to George Mason's claim that the grant of jurisdiction over "cases" arising under the Constitution was both too broad and too indeterminate: $:^{186}$

The first class of cases to which its jurisdiction extends are those which may arise under the Constitution; and this is to extend to equity as well as law. It may be a misfortune that, in orgamizing any government, the explication of its authority should be left to any of its coördinate branches. There is no example in any country where it is otherwise. There is a new policy in submitting it to the judiciary of the United States. That causes of a federal nature will arise, will be obvious to every gentleman who will recollect that the states are laid under restrictions, and that the rights of the Union are secured by these restrictions. They may involve equitable as well as legal controversies. ${ }^{187}$

Madison agrees with Hamilton's understanding in two respects: that the framers had made a structural decision to give the federal courts, rather than Congress, responsibility for ensuring state compliance with the

184. The Federalist No. 80, at 535 (Alexander Hamilton) (Jacob E. Cooke ed., 1961).

185. For the inportant recognition that Hamilton's statement implicitly speaks of actions in law ("correct") and equity ("restrain"), and thus echoes the reference in Article III to "cases, in law and equity," see Gibbons, supra note 84, at 1910 \& n.104; cf. Massey, supra note 4, at 95 \& n.172 (referring only to actions in law).

186. 3 Elurot's DeBATES, supra note 50, at 521-22 (remarks of George Mason).

187. Id. at 532 (remarks of James Madison). 
Constitution, and that the courts were to exercise this power in law and equity. The comments of Hamilton and Madison thus suggest that the constitutional grant of jurisdiction over "cases arising under this Constitution" was meant primarily as a check on the power of the states. ${ }^{188}$

In addition to intending to subject states to suit in cases arising under the Constitution, the framers may well have intended to subject states to suit in cases arising under properly enacted laws of the United States Congress. Within its defined sphere of legislative conpetence, Congress had the power to bind the states and to regulate to the exclusion of state law. Such, certainly, was the accepted interpretation of the enumeration of legislative powers in Article I, Section 8, and of the provision in the Supremacy Clause that duly enacted federal legislation was to be the supreme law of the land. ${ }^{189}$ Such an understanding of Congress' power to bind the states lay at

188. The drafting history of Article III certainly bears out the suggestion that the "arising under" grant for constitutional cases opcrated principally to add the enforcement of limits on state and not on federal power to the work of the federal judiciary. As it had been reported by the Committee of Detail, Article III did not contain an explicit provision for hearing cases that implicate the Constitution; the "arising under" grant was limited to cases arising under laws passed by Congress. See supra note 152 and accompanying text. The framers assumed, however, that the federal courts would review federal legislation by measuring statutes against the limits on federal power appearing in the Constitution. See HART \& WEChSLER, supra note 10, at 8-10. Cases arising under federal law would, then, occasionally present constitutional questions. But the grant of power over cases arising under the Constitution was not addressed to such federal limits inasmuch as the framers had already committed the resolution of such limits to the federal courts.

St. George Tucker identified precisely this overlap between the power of federal courts to check state action under the "arising under the Constitution" grant and their power to check federal excesses under the "laws" grant. Tucker pointed out that the general words "arising under the Constitution" include "what is comprehended in the next clause, viz. Cascs arising under the laws of the United States. But as contra-distinguished from that clause, it comprehends some cases afterwards enumerated, e.g. Controversies between two or more states; . . . which may arise under the constitution, and not under any law of the U. States." 1 BLACKSTONE, supra note 89, app. at 418-19. Like Hamilton and Madison, Tucker thus suggested that the distinct contribution of the "arising under the Constitution" grant was its provision for enforcement of constitutional prohibitions against the states.

189. Consider a pamphlet written by Timothy Ford of South Carolina one year prior to the Court's decision in Chisholm:

[The United States] may, therefore, pass laws, directly obligatory upon each state. If under one of those laws, so passed, a case should arise; that case, and necessarily the state, relative to which it should arise, would, from the very terms of this clause, be subject to the judicial power.

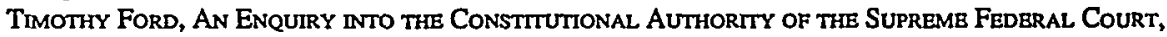
over the Several States in Their Polmtical Capactiy 30 (1792), quoted in William A. Fletcher, Correspondence (Exchange on the Eleventh Amendment), 57 U. CHI. L. REv. 117, 131, I38 (1990). Ford then attributed this conclusion to his view that the states were made subject to federal legislation and that the judicial power was coextensive with the legislative. ForD, supra, at 30, quoted in Fletcher, supra, at 138 n.22.

Justice Wilson expressed the same view in Chisholm v. Georgia, 2 U.S. (2 Dall.) 4I9, 464 (1793). Wilson noted that the national government enjoyed coercive powers over individuals, powers that it had lacked under the Articles. Then, Wilson responded to the claim that "the present constitution operates only on individual citizens, and not on states." Wilson rejected this argument, noting first that it would introduce a defect similar to that present under the Articles. He then observed that the Constitution expressly gives Congress the power to revise and control state legislation-a fact that for Wilson proved the general principle of congressional supremacy. See id. (Wilson, J.) (referring to the qualified prohibitions in Article I, $\S 10$ that require congressional approval of certain state action). 
the heart of Hamilton's famous discussion of shared sovereignty in The Federalist No. $32^{190}$ and his assumption in The Federalist No. 36 that Congress could impose legally binding requisitions on the states. ${ }^{191}$ In hearing cases arising under the laws of the United States the federal courts were both to enforce the duly enacted congressional statutes against the states, if appropriate, and to protect the states from federal enactments that exceeded the boundaries of Congress' enumerated powers. ${ }^{192}$

Finally, the framers contemplated that states were to appear as parties in federal court "cases" that implicated treaties. As Judge Gibbons has shown in his masterful discussion, the framers were well aware that southern states had defied their obligations under the 1783 Treaty of Peace with Great Britain. ${ }^{193}$ This defiance led to the Supremacy Clause's declaration that treaties are binding on the states and Article III's provision for federal jurisdiction over cases arising under duly ratified treaties. ${ }^{194}$

The Supreme Court's recent decision in New York v. United States, 112 S. Ct. 2408 (1992), held on Tenth Amendment grounds that Congress may not legislatively require the states as such to adopt and enforce federal standards into their municipal law. Justice O'Connor's opinion for the Court, contra Justice Wilson, claims historical support for the proposition that in empowering Congress to regulate the citizens directly, the framers disabled Congress from regulating through the agency of member states. Id. at 2422-23. Although full consideration of the historical issue lies beyond the scope of this piece, the Constitution contains a nunber of provisions that appear to authorize Congress to regulate the states as such. See Janies E. Pfander, Environmental Federalism in Europe and the United States: A Comparative Assessment of Regulations Through the Agency of Member States, in ENVIRONMENTAL Federalism: The European Union and the UnIred States (John Braden et al. eds., forthcoming 1994) (arguing that the Constitution empowers Congress to issue requisitions to the states for militia forces and tax revenues, to make use of state courts for the enforcenient of federal claims, and to implement the Full Faith and Credit Clause through legislation directed at the states); see also $\mathrm{H}$. Jefferson Powell, The Oldest Question of Constitutional Law, 79 VA. L. REv. 633 (1993) (arguing that O'Connor overstates the historical case); Saikrishna B. Prakash, Field Office Federalism, 79 VA. L. Rev. 1957 (1993) (arguing that Congress may commandecr state executive and judicial officers into federal service but may not instruct the state legislatures).

190. In The Federalist No. 32, Hamilton responded to the claim that the power of the federal government to inpose taxes would essentially eliminate the taxing power of the states, either by drying up available sources of revenue or by forbidding the states to levy taxes on any sources within federal purview. The core of Hamilton's argument lay in his assertion that the state governments "would clearly rctain all the rights of sovereignty which they before had and which were not by [the plan of the Convention] exclusively delegated to the United States." THE FederalisT No. 32, at 200 (Alexander Haniilton) (Jacob E. Cooke ed., 1961). Note that Hamilton's reference to the plan of the convention also appeared in his discussion of retained state sovereign immunity in The Federalist No. 81. See infra notes 292-315 and accompanying text.

191. The Federalist No. 36, at 226 ("II]f the exercise of the power of internal taxation by the Union, should be discovered on experiment, to be really inconvenient, the Fœederal [sic] Government may then forbear the use of it and have recourse to requisitions in its stead.").

192. See The Federalist No. 33, at 206-07 (Alexander Hamilton) (Jacob E. Cooke ed., 1961) (noting that supreme federal law only includes that which Congress enacts within its enumerated powers, and declaring that usurpations by Congress would deserve treatment as such); 2 ELIrot's DEBATES, supra note 50, at 489 (remarks of James Wilson) (arguing that Article III judges possess the independence to declare null and void any law inconsistent with the Constitution); supra note 188.

193. See Gibbons, supra note 84 , at 1899-902.

194. James Wilson was quite clear on the point in the ratification debates in Pennsylvania. See 2 ELLror's DeBates, supra note 50, at $489-90$ (arguing that states should be subject to suit to enforce treaties). 
By the same token, the framers surely expected that federal admiralty courts would adjudicate claims involving the states. States had appeared as interested parties in capture and prize litigation under the Articles of Confederation. ${ }^{195}$ The inability of the Supreme Court's precursor, the Court of Appeals, to render judgments binding on the states in such cases was among the reasons the framers recognized the need for a national court with final authority over admiralty and maritime cases. ${ }^{196}$ The law-ofnations sovereign immunity, which led to the dismissal of maritime claims during the Articles of Confederation period, ${ }^{197}$ underscored the inadequacy of state tribunals. In admiralty and maritime "cases," as in "cases" arising under federal law, therefore, the framers had good reason to extend the judicial power to claims brought against the states as defendants.

\section{B. The Distinction Between "Cases" and "Controversies"}

Although the Court's original jurisdiction applies literally to all stateparty "cases" that appear on the jurisdictional menu, the menu's reference to a variety of "controversies" complicates the interpretive task. ${ }^{198}$ To sort out the complexity, we must consider the difference in meaning that the

The grant of alienage jurisdiction also grows out of the framers' desire to assure compliance with the Treaty of 1783. In a provision that was nominally even-handed but in practice operated to favor British creditors, Article IV of the Treaty agreed that "creditors on either side, shall meet with no lawful impediment to the recovery of the full value in sterling money, of all bona fide debts, herctofore contracted." HoSEN, supra note 110, at 33 (reprinting 1783 Treaty of Peace). The framers regarded the state courts as inadequate to the task of assuring compliance with this obligation and thus included a provision for federal courts to hear claims brought by citizens and subjects of foreign states. See 2 Elliot's Debates, supra note 50, at 491-92 (remarks of James Wilson) (arguing that alienage jurisdiction is necessary to supply an impartial alternative to the state eourts, since tender laws had made collection of just debts by foreign citizens quite difficult and such jurisdiction is necessary to the restoration of private credit).

195. Capture and prize litigation under the Articles of Confederation often involved funds in which a state claimed an interest as the sovereign power that had financed the eapture. See Bouroulonon, supra note 50, at $46-47$ (describing the division of prize funds between owner, crew, and the sovercign power that bad financed the vessel making the seizurc).

196. Id. at 328-30. In the decades immediately following ratification of the Constitution, states appeared as interested parties in a variety of admiralty proceedings. See United Statcs v. Bright, 24 F. Cas. 1232 (C.C.D. Pa. 1809) (No. 14,647) (State of Pennsylvania); United States v. Peters, 9 U.S. (5 Cranch) 115 (1809) (State of Pennsylvania); Governor of Georgia v. Madrazo, 26 U.S. (1 Pet.) 110 (1828) (State of Georgia). In Madrazo, the most significant such case, Marshall not only held that the appearance of the governor of the state in his official capacity was tantamount to the appearance of the state itself, but also made the tantalizing suggestion that such "cases" fell within the Court's original jurisdiction. See infra note 369 and accompanying text.

197. See supra note 127.

198. After describing federal question, ambassador, and admiralty "cases," the menu proceeds to list a variety of "controversies" that include disputes involving state parties. It thus authorizes federal courts to hear "controversies" between two or more states, "controversies" between a state and foreign states, and "controversies" between a state and the citizens or subjects of another state or country. For the text of the jurisdictional menu, see supra text accompanying note 175. Many observers have assumed that these terms are more or less synonymous, commonly describing justiciability limits as the "case or controversy" requirement. For a powerful critique of this assumption of synonymity that draws on a variety of structural and historical arguments, see Robert J. Pushaw, Jr., Article III's Case/ Controversy Distinction and the Dual Functions of Federal Courts, 69 Notre DAME L. Rev. 447 (1994) 
framers ascribed to the words "cases" and "controversies." As will become apparent, the framers used "cases" to confer subject matter jurisdiction on the federal courts in the broadest terms possible. Thus, the term "cases" includes both criminal and civil proceedings, whereas the term "controversies" embraces only matters of a civil nature. By the same token, the framers intended the term "cases" to apply broadly to all disputes that touched upon subjects of national concern, quite without regard to the identity of the parties. "Controversies," by contrast, encompassed only disputes between the identified parties and did not necessarily involve subjects of federal law.

Each of these distinctions between "cases" and "controversies" has important implications for the scope of the Court's original jurisdiction and for a complete understanding of the ratification debates over the scope of state sovereign immunity. In keeping with the literal terms of the clause, and in contrast to the traditional account, I read the reference to state-party "cases" as encompassing federal question claims involving state parties. In addition, I argue that state-party "cases" can be fairly read to encompass all of the state-party "controversies" that appear on the menu, on the theory that the broader term "cases" also encompasses the civil matters described as "controversies." I agree, in short, with the traditional claim that diverseparty "controversies" involving the states will suffice to confer original jurisdiction; I simply argue that the jurisdiction also encompasses federal question "cases" involving states.

The first important distinction consists of the "now-familiar" principle $^{199}$ that jurisdiction over "cases" depends on the subject in dispute and that jurisdiction over "controversies" depends entirely on the identity and status of the parties. The best known articulation of the distinction appears in Chief Justice Marshall's opinion for the Court in Cohens v. Virginia: ${ }^{200}$

Jurisdiction is given to the courts of the Union, in two classes of cases. In the first, their jurisdiction depends on the character of the cause, whoever may be the parties. This class comprehends "all cases in law and equity arising under this constitution, the laws of the United States, and treaties made, or which shall be inade, under their authority." . . . In the second class, the jurisdiction depends entirely on the character of the parties. In this are comprehended "controversies between two or inore states, between a state and citizens of another state," and "between a state and foreign states, citizens or subjects." If these be the parties, it is entirely unimportant, what may be the subject of controversy. ${ }^{201}$

(arguing that the framers envisioned a law-expounding role for the federal courts in "cases" and a dispute-resolution role in "controversies").

199. Jackson, supra note 91 , at 20.

200. 19 U.S. (6 Wheat.) 264 (1821); see also Martin v. Hunter's Lessee, 14 U.S. (1 Wheat.) 304, 333-36 (1816) (Story, J.); United States v. Texas, 143 U.S. 621, 646 (1892) (Harlan, J.).

201. Cohens, 19 U.S. (6 Wheat.) at 378. 
For Marshall, then, Article III drew a distinction between the federal subjects embraced by jurisdiction over "cases" and the often non-federal subjects embraced by party-based jurisdiction over "controversies."

Two corollaries follow from Marshall's distinction between the federal subject matter of "cases" and the non-federal focus of party-based "controversies." As Marshall notes, the distinction between cases and controversies implies that federal courts may hear cases "whoever may be the parties." Such a reading of Article III implies that states may appear as defendants in all "cases" to which the judicial power extends, as well as in those "controversies" in which they appear as one of the named parties. It thus suggests a textual basis for concluding that states were subject to the Court's original jurisdiction in federal question cases. ${ }^{202}$ In light of its importance, it is worth noting that Marshall's reading in Cohens was no spur-of-the-moment invention: St. George Tucker's analysis of Article III in 1803 had reached precisely the same conclusion ${ }^{203}$ as had Edmund Randolph's in 1790.204

Marshall's suggested distinction between "cases" and "controversies" also offers an important key to a full understanding of the scope of the states' common law or domestic immunity from suit in federal court. As to "cases"-which, as defined by the jurisdictional menu, implicate federal law-the Supremacy Clause was available to trump any claim of common law immunity. As to non-federal "controversies," however, no supreme federal law would justify the federal courts in departing from the common law rule that immunized states from individual suits for danıages. Justice Iredell made precisely this point in dissenting from state suability in the common law contract action in Chisholm v. Georgia, ${ }^{205}$ as did Hamilton in his famous digression on the subject in The Federalist No. 81. ${ }^{206}$ A failure to appreciate this important distinction accounts for much of the confusion surrounding the issue of sovereign immunity.

202. Cf. United States v. Texas, 143 U.S. at 641 (holding that the Court had original jurisdiction of a suit brought by the United States against a state). Marshall, however, rejected this reading. See infra text accompanying note 366 .

203. In an appendix to his edition of Blackstone's Commentaries, St. George Tucker explains that the jurisdiction over cases arising under the Constitution encompasses suits to enforce prohibitions against the states directly. See supra note 188 . The significance of Tucker's analysis lies in his recognition that the extension of "controversy" jurisdiction to disputes involving state parties does not narrow the scope of federal power over "cases." Rather, he simply assumed that subsequent grants overlapped to some extent with jurisdiction over "cases" and thus broadened federal judicial power to encompass non-federal disputes between the parties identified. See supra note 188.

204. See infra notes $334-48$ and accompanying text.

205. Justice Iredell specifically noted that the action in Chisholm was based on the common law of assumpsit, arose between diverse parties, and presented no issue of federal law. As to such non-federal claims, Iredell doubted that Congress could impose liability on the states and certainly denicd the Court's ability to do so. See Chisholm v. Georgia, 2 U.S. (2 Dall.) 419, 435-36 (1793) (Iredell, J., dissenting).

206. See infra note 300 and aecompanying text. 
Article III secondly distinguishes between "cases" that embrace both civil and criminal proceedings and "controversies" that apply to civil proceedings alone. A variety of late eighteenth and early nineteenth century sources support the criminal-civil distinction between "cases" and "controversies." To the sources collected by Professor Fletcher, ${ }^{207}$ we can add the confirming references that appear in Story's opinion in Martin v. Hunter's Lessee $^{208}$ and in Peter Du Ponceau's lectures on the federal cominon law of crimes, ${ }^{209}$ among others. ${ }^{210}$

This impressive confluence of views undoubtedly owes much to the language of the Constitution, which consistently uses the term "cases" to

207. See William A. Fletcher, The "Case or Controversy" Requirement in State Court Adjudication of Federal Questions, 78 CALIF. L. REv. 263, 266-67 (1990) (citing Chisholm v. Georgia, 2 U.S. (2 Dall.) 419, 431-32 (1793) (Iredell, J., dissenting); 1 BLACKSTONE, supra note 89, app. at 420 21; and 3 STORY, supra note 173, at 536 n.2). Professor Fletcher's scholarship has persuaded most observers. See Daniel J. Meltzer, The History and Structure of Article III, 138 U. PA. L. REv. 1569, 1575 \& n.18 (1990) and sources cited therein. But see Amar, supra note 12, at 244 n.128 (arguing that "cases" and "controversies" are "legally synonymous" words); Akhil R. Amar, Reports of My Death Are Greatly Exaggerated: A Reply, 138 U. PA. L. Rev. 1651, 1664 n.54 (1990) (arguing that Meltzer equates, rather than distinguishes, cases and controversies in his argument). Amar's reluctance to accept the importance of the distinction flows from his perception that the Distribution Clause uses the tcrm "cases" to encompass mattcrs that Article III earlier describes as "controversies." Amar, supra note 12, at $244 \mathrm{n} .128$. But as we shall see, it is possible to read the broader term "cases" as encompassing both cases and controversies without concluding that the framers did not use the two terms to distinguish civil from criminal matters. See infra note 217.

208. 14 U.S. (1 Wheat.) 304, 335-36 (1816) (distinguishing between "cases" and "controversies" and explaining that the "[first] class of cases would embrace civil as well as criminal jurisdiction").

209. See Peter S. Du Ponceau, A Dissertation on the Nature and Extent of the JURISDICTION OF THE COURTS OF THE UNITED STATES 1 (photo. reprint 1972) (1824) (explaining that the heads of "controversy" jurisdiction "are all understood to be matters of mencly civil jurisdiction").

210. A variety of contemporary observers read the term "cases" in the menu to include both civil and criminal matters. See 3 Records OF THE FEDERAL Convention, supra note 77, at 221 (remarks of Luther Martin) (arguing to Maryland legislature that the extension of the Court's appellate jurisdiction in "all cases" embraced criminal appeals and criticizing such appellate review on the ground that appeals in criminal matters were unknown to the common law); 2 ELLIOT's DeBATES, supra note 50, at 409 (proposal to New York ratification convention to clarify that the Supreme Court's original jurisdiction over "cases" in which a state shall be a party did not apply to criminal prosecutions); Letters from The Federal Farmer (No. III) (Oct. 10, 1787), in 2 The Complete ANTI-Federalist, supra note 50, at 234, 245 ("Many sensible men suppose that cases before mentioned [in the Distribution Clause's provision for appellate jurisdiction] respect, as well the criminal cases as the civil ones, mentioned antecedently in the constitution ...."); Essays of Brutus (No. XIV) (Feb. 28, 1788), supra note 50, at 431, 432 (arguing that because the jurisdictional menu enumerates all "cases to which the judicial power [of the United States] shall extcnd, whether civil or criminal," the grant of appellate jurisdiction over "cases" allows appeals "in all criminal as well as civil causes"); Letter from Samuel Chase to Chief Justice John Marshall (April 24, 1802), in Haskins \& JoHNSON, supra note 52, at 172-73 n.182 ("By the Constitution these [inferior] Courts were invested with Jurisdiction (Civil \& Criminal) of all Cases, in Law, and Equity arising under the Constitution, and Laws of the Umited States . . . ."). Such interpretations shed no direct light on the meaning of "controversies" but do confirm my claim as to the breadth of the term "cases." See also 3 ELurot's DeBATES, supra note 50, at 524 (remarks of George Mason) (referring to the failure of the Constitution to require trial by jury in common law "controversies"). Article III's explicit guarantee of jury trials in all criminal trials makes clear that Mason understood the tcrm "controversies" to exclude criminal matters. 
include criminal proceedings. ${ }^{211}$ The more limited scope of the term "controversies" emerges most clearly from the implications for federal judicial power of the doctrine that courts lacked the power to execute another sovereign's criminal or penal statutes. ${ }^{212}$ This doctrine had deep roots in the common law, which regarded civil actions for private wrongs as inherently transitory and subject to litigation in any sovereign's court but regarded the prosecution of criminal or penal offenses as localized in the courts of the sovereign where the offense was committed. ${ }^{213}$ Although Professor Warren has raised important questions about the doctrine's iminutability, many thought the doctrine barred the federal courts from taking cognizance as an original matter of state penal proceedings and criminal prosecutions. ${ }^{214}$

This limitation on the federal execution of state criminal laws explains why so many have interpreted the term "controversies" as encompassing disputes of a transitory civil nature rather than of a fixed criminal nature. Recall that under the conception of the menu advanced by Marshall in Cohens, the broader term, "cases," exhausts the federal law subjects of national judicial cogmizance and the narrower term, "controversies," reaches disputes involving specified parties over matters of non-federal law. ${ }^{215}$ Although the framers expected the federal courts to entertain as "cases" federal criminal prosecutions arising under the laws of the United States, they undoubtedly intended to leave the great mass of state criminal prosecutions in the hands of the state courts in keeping with the fundamental con-

211. Thus, Article I's provision for Congress to punish treason and crimes on the high seas nicely dovetails with the provision in Article III for federal courts to hear "cases" arising under the laws of the United States and "cases" of admiralty and maritime jurisdiction. Moreover, the reference to "cases" of impeachment, in Article I, Section 3 obviously refers to matters of a criminal nature; indeed, "cases" of impeachment appear as an exception to the provision in Article III that requires the trial of all fcderal crimes to a jury. Similarly, Article I extends the legislative power of Congress over the District of Columbia to "all Cases whatsoever," a reference understood to give Congress power to prescribe both criminal and civil law. See Du PONCEAU, supra note 209, at 69-73.

212. See supra note 173 and accompanying text; see also Cohens v. Virginia, 19 U.S. (6 Wheat.) $264,290-375$ (1821) (argument of counsel for plaintiff) (asserting that the courts of the United States do not have jurisdiction over state criminal cases).

213. Compare 4 BLACKSTONE, supra note 89 , at 2 (distinguishing private wrongs, which infringe the rights of individuals, from public wrongs, which affect the whole community); id. at 293 (characterizing private wrongs to the person as transitory); and JosepH STORY, COMMENTARIES ON THE CoNflict of LAws 450 (1834) (distinguishing "transitory" personal civil actions from "local" actions affecting real property) with id. at 516 ("The common law considers crimes as altogether local, and cognizable and punishable exclusively in the country, where they are committed.").

214. For the conflicting views of Justice Story and Professor Warren on the power of courts to entertain criminal or penal actions of other sovereigns, see supra note 173. The doctrine did not, of course, bar the courts from executing the civil laws of other sovcreigns. It was commonplace that courts in civil disputes might well apply the laws of a different country. See The Federalist No. 82, at 555 (Alexander Hamilton) (Jacob E. Cooke ed., 1961) ("The judiciary power of every government looks beyond its own local or municipal laws, and in civil cases lays hold of all subjects of litigation between parties within its jurisdiction though the causes of dispute are relative to the laws of the most distant part of the globe."); see also 3 Elluot's Debates, supra note 50, at 556-57 (remarks of John Marshall) (assuming that federal courts would apply choice-of-law principles to select law governing transitory disputes between diverse parties).

215. See supra text accompanying notes 199-201. 
ception of such prosecutions as non-transitory. ${ }^{216}$ St. George Tucker offered precisely this structural argument in support of his claim that "controversies" encompassed only matters of a civil nature. He thus observed not only that he had never heard reference to a "criminal controversy," but also that an interpretation of the term "controversy" to encompass criminal matters could improperly shift crimes committed within a state by non-citizens into the federal system. ${ }^{217}$

216. It is certainly true, as Warren points out, that Congress has authorized the removal of certain kinds of state criminal proceedings, notably those instituted against federal officers. See WARrEN, supra note 173, at 545-46 (citing Tennessee v. Davis, 100 U.S. 257 (1880)). But as the Court has recently made clear, such removal powers extend only to criminal prosecutions in which the officer presents a federal defense. See Mesa v. California, 489 U.S. 121 (1989) (interpreting removal statute to bar removal in the absence of a federal defense; refusing to accept government's argument that Tennessee $v$. Davis extended removal to non-federal claims). By the saine token, the framers may have expected the federal courts to hear state criminal prosecutions of ambassadors, other public ministers, and consuls and to apply the federal (or law of nations) defense of ambassadorial immunity to such claims. See, e.g., Pennsylvania v. Kosloff, 5 Serg. \& Rawle 545 (Pa. Ct. Oy. \& Term. 1816) (holding that state courts lack jurisdiction over criminal prosecutions of foreign consuls; such prosecutions must go forward on Supreme Court's original docket).

The assertion of federal jurisdiction over state prosecutions that present federal questions does not threaten the general principle that the framers meant to leave state criminal prosecutions in the hands of state courts, at least where they fail to present a federal question and are on the federal docket solely on the basis of diversity. Thus, both Iredell and St. George Tucker explained that "controversy" jurisdiction would simply not supply any basis for the assertion of criminal jurisdiction by the federal courts. See infra note 217 .

217. See 1 Blackstone, supra note 89 , app. at 420 . Like St. George Tucker, Justice Iredell's dissent in Chisholm expressly drew the connection between the two explanations of the difference in meaning of "cases" and "controversies." Iredell's comment appears in the course of comparing the unqualified grant of "controversy" jurisdiction in the Constitution and the more narrowly tailored reference to "civil controversies" in the original jurisdiction provision of Judiciary Act:

I do not doubt every reasonable man will think [the Act's narrowing reference to "civil controversies"] well warranted, for it cannot be presumed, that the general word "controversies" was intended to include any proceedings that relate to criminal cases, which in all instances that respect the same govemor only, are uniformly considered of a local nature, and to be decided by its particular laws. The word "controversy" indeed, would not naturally justify any such construction, but nevertheless it was perhaps a proper instance of caution in congress to guard against the possibility of it.

Chisholm v. Georgia, 2 U.S. (2 Dall.) 419, 431-32 (1793) (Iredell, J., dissenting).

Here, then, we have the claim that "controversy" was limited to civil matters as a matter of both natural meaning and constitutional structure. The analysis of St. George Tucker and Iredell offers an important clarification of one confusing aspect of the ratification debates over the Original Jurisdiction Clause. Both New York and Rhode Island considered amondments to the Constitution affirming that "the judicial power of the United States, in cases in which a state shall be a party, is not to be construed to extend to criminal prosecutions." 2 Eluiot's Debates, supra note 50, at 409 (proposal to New York ratifying convention); see also 2 DocumentaRY History of THE CONSTITUTION, supra note 109, at 317 (amendment adopted by the Rhode Island convention). Such aincndments rest on two assumptions with which 1 generally agree: that the grant of original jurisdiction extended to "cases" involving states and that "cases" encompassed criminal proceedings. The saine concerns that were at work in the New York and Rhode Island legislatures probably led the drafters of the Judiciary Act to limit the Court's original jurisdiction to "controversies of a civil nature"-language designed to make doubly sure that the Court would not ordinarily entertain original state prosecutions.

However, the fears expressed in New York and Rhode lsland and the caution evinced by Congress were largely unfounded. They rest on the assumption that the term "cases" in the Original Jurisdiction Clause picks up only the diverse party heads of jurisdiction, those involving disputes between states and diverse citizens and foreign subjects. On such a reading, which both Iredell and St. George Tucker were 
Finally, certain evidence suggests that the framers inay have viewed the distinction between "cases" and "controversies" as dividing the work of the federal courts into inandatory and permissive tiers of jurisdiction. In each instance in which Article III addresses "cases," the provision extends the judicial power to "all Cases." The word "all" appears three times in the jurisdictional menu and each time it precedes a grant of "case" jurisdiction. By contrast, the inenu omits the word "all" in the course of extending jurisdiction to the six categories of "controversy" jurisdiction. Coupled with other obligatory language in Article $\mathrm{III},{ }^{218}$ the selective statement that the judicial power "shall extend to all Cases" suggests that Article III requires Congress to confer final authority on the federal courts to resolve all "cases" on the menu.

at pains to reject, the reference to "cases" in the Original Jurisdiction Clause may appear to require states to prosecute non-citizens in the Supreme Court. Once we recognize that the framers used "cases" in the Original Jurisdiction Clause to sweep in both federal question "cases" and party-based "controversies," and that controversies encompassed only civil matters, the clause presents no threat of the kind that worried New York and Rhode Island.

Let me illustrate this understanding through the consideration of a hypothetical state-law criminal or penal action, brought by the State of Virginia against two defendants-one of whom makes his home in Virgimia and one of whom does not. As to the resident of Virginia, the action clearly fails to satisfy the requirements of diversity and falls outside federal cognizance on that ground alone. As to the noncitizen, the requirement of diversity is satisfied but the claim, inasmuch as it seeks to enforce a criminal or penal statute of the state, does not present a "controversy" within the meaning of Article III. Thus, in a little noted section of Cohens v. Virginia, 19 U.S. (6 Wheat.) 264, $398-99$ (1821), Chicf Justice Marshall suggests that "perhaps" federal courts nuay not entertain original actions based on the penal or criminal laws of the states.

Now suppose that one or both of the defendants asserts a federal question defense. We now have a federal question "case" of the kind that comes within Article III. But such a case does not necessarily present a federal question that demands an original federal docket. Federal courts might assert appellate jurisdiction over the action, either by reviewing a final judgment of the state court as in Cohens, or by exercising removal jurisdiction over the prosecution under the doctrine of Tennessee v. Davis, 100 U.S. 257 (1880) - assuming a statutory basis for such removal existed. Such removal jurisdiction, at least under Justice Story's theory in Martin v. Hunter's Lessee, 14 U.S. (1 Wheat.) 305 (1816), would represent a species of appellate jurisdiction.

All of this serves to underscore the aptness of Chief Justice Marshall's conclusion that the dispute in Cohens, from which I developed the hypothetical, was not of a kind that might properly originate in the federal courts. Marshall based this conclusion on two factors: the federal courts' general inability to exercise origimal jurisdiction over state criminal or penal matters and the failure of the Cohens action to present a federal question of the kind necessary to support original jurisdiction. See infra notes 363, 371. In other words, Marshall thought that something like the face-of-the-coniplaint rule, which the Court later adopted as a matter of statutory construction in Louisville \& N.R.R. v. Mottley, 211 U.S. 149 (1908), overruled by Smith v. Kansas City Title \& Trust Co., 255 U.S. 180 (1921), operated as a limit on the scope of original jurisdiction. See also Osborn v. Bank of United States, 22 U.S. (9 Wheat.) 738, 883-901 (1824) (Johnson, J., dissenting) (arguing that the federal ingrcdient on which Marshall relied was too hypothetical or insubstantial to support original federal question jurisdiction). One need not agree with Justice Johnson's critique of Osborn or view the face-of-the-complaint rule as constitutionally mandated to perceive that disputes will evade original federal adjudication unless, at the time of the filing, either the subject of the dispute or the alignment of the parties meets the requirements of Article III. For a critique of Osborn and a claim that Justice Johnson's dissent reprcsented the thenconventional view of arising-under jurisdiction, see David E. Engdahl, Federal Question Jurisdiction Under the 1789 Judiciary Act, 14 OKLA. CrTY U. L. Rev. 521, 526-29 (1989).

218. "The judicial Power of the United States, shall be vested ...." 
First articulated in tentative form in his opinion in Martin v. Hunter's Lessee, ${ }^{219}$ Justice Story's theory of the mandatory character of federal question jurisdiction has been recently restated in Professor Amar's important works on the two tiers of federal jurisdiction. ${ }^{220}$ Amar collects an impres-

219. 14 U.S. (1 Wheat.) 304, 334-35 (1816). Story first distinguished "cases" from "controversies" by pointing out that the first class involved subjects of natioual importance. He next observed that while the jurisdictional menu extended the judicial power to "all Cases," the word "all" did not precede the reference to "controversies." Id. at 334. Reluctant to ascribe the difference in wording to mere accident, Story suggested that the framers may well have intended "imperatively to extend the judicial power, either in an original or appellate form, to all cases; and in the latter class, to leave it to Congress to qualify the jurisdiction, original or appellate, in such manner as public policy might dictate." Id.

A less well-known but equally elegant exposition of the theory appears in Henry Wheaton's defense of the Court's opinion in Cohens v. Virginia, 19 U.S. (6 Wheat.) 264 (1821). Writing in 1821 under the pen name "A Federalist of 1789" for the New York newspaper The American, Wheaton (the Supreme Court reporter and a close friend of Justice Story) mounted a careful textual defense of the mandatory character of the Court's jurisdiction over "cases," by which he chiefly meant those arising under the Constitution, laws and treaties of the United States. See A Federalist of 1789, supra note 1. Wheaton repeatedly eniphasized the mandatory language of Article III's reference to "all cases" and pointedly distinguished it from the permissive reference to "controversies." Wheaton thus observed that although "Congress ... is not at liberty to restrain" the first class of jurisdiction, the second class "may, in the discretion of the national legislature, be applied to all or to some controversies only as shall seem expedient." A Federalist of 1789, The Dangers of the Union (No. 5), AMERICAN (New York), Aug. 2, 1821 , at 1.

Having established the mandatory character of federal jurisdiction over "cases," Wheaton turned to the Distribution Clause and specifically to its provision for Supreme Court appellate jurisdiction in "all the other cases before mentioned." Wheaton explicitly linked the reference to "cases" in the Distribution Clause to the earlier extension of judicial power to " 'all cases . . . arising under the constitution,' \&c." Id. After showing that the Constitution left the states to resolve in the first instance many of the "cases" on the menu, and after reeinphasizing the mandatory character of the relevant language, Wheaton concluded that the Constitution contemplated the very exercise of appellate jurisdiction at issue in Cohens.

220. Professor Amar's work on the mandatory and permissive tiers of federal jurisdiction surely represents one of the most significant contributions to our understanding of Article III in recent years. He first articulated the theory in 1985, before he joined the faculty at Yale. See Amar, supra note 12. He has since refined his theory and extended it in an inportant, if flawed, analysis of the Court's original jurisdiction, see Amar, supra note 10, and in an assessnient of the meaning of the Eleventh Amendment, see Amar, supra note 84; see also Akhil R. Amar, The Two-Tiered Structure of the Judiciary Act of 1789, 138 U. PA. L. REv. 1499 (1990) (concluding that the Act largely conforms to his two-tier thesis).

Although I find Amar's work quite persuasive in general, the extension of his two-tier thesis to the Court's original docket rests on a fundamental misconception. Annar begins with the assumption that the Court's original jurisdiction over state-party "cases" encompasses only permissive tier, diverse-party "controversies." See Amar, supra note 12, at 254 n.160. Such an assuinption leads Amar, in keeping with his theory, to conclude that Congress may strip the Court of its original cognizance of such matters. See id.; Amar, supra note 10, at 478-88. Such a conclusion seems completely mconsistent with the language of the clause, which declares (using terms that Amar views as mandatory elsewhere in Article III) that the Court "shall have" original jurisdiction. See, e.g., Amar, supra note 12, at 255 n.165 (arguing that although Congress may make exceptions to the Court's appellate jurisdiction, it must, in accord with the phrase "shall extend," provide a federal forum for mandatory tier "cases"); Amar, supra, at 1507 (emphasizing mandatory thrust of "shall"). Amar's claim also departs from the overwhelming weight of scholarly opinion, which regards the Court's original jurisdiction as inandatory, self-executing and irreducible-a point he himself acknowledges. See id. at 1523 \& nn.72-74.

Amar's commitment to a non-federal view of the Court's original jurisdiction over state-party "cases" also pushes him to adopt a variety of other questionable conclusions. For one, Amar flatly refuses to accept the case-controversy distinction, see supra note 207 , and does so because he reads the 
sive array of textual and structural support for Story's claim that the framers envisioned both a mandatory and permissive tier of federal jurisdiction. As to the most important class, federal question and admiralty "cases" in the mandatory tier, Amar argues that the language and structure of the Constitution require Congress to provide for final judicial resolution in a federal court. ${ }^{221}$ As to "controversies" in the permissive tier, Congress may provide for federal judicial resolution as it sees fit. ${ }^{222}$

\section{Implications of the Case-Controversy Distinction for Original Jurisdiction}

The framers' distinction between "cases" and "controversies" supports the claim that the Original Jurisdiction Clause authorizes the Court to hear all federal question and admiralty claims against the states. The text of the Original Jurisdiction Clause applies to "all Cases" in which a state shall be a party-a formulation that embraces the "cases" that the jurisdictional

reference to "cases" in the state-party Original Jurisdiction Clause as encompassing "controversies," see Amar, supra note 12, at 244 n.128. For another, Amar argues quite curiously that the term "those" in the Original Jurisdiction Clause refers to "cases" involving state parties, rather than "all" such cascs. See Amar, supra note 12, at 254 n.160; Amar, supra note 10, at 480 . But see infra note 225 (responding to Amar's argument in greater detail). Such hair-splitting might seem inexplicable but for the fact that the term "all" supplies an important key to Amar's two-tier theory. See Amar, supra note 12, at 242 (arguing that Article III divides jurisdiction into mandatory and pcrmissive tiers by using "all" to describe mandatory "cases" and omitting "all" in the description of "controversies"); Amar, supra, at 1507-08 (same). Amar thus works quite diligently (too diligently?) to explain away the apparcnt reference to "all" cases in the Original Jurisdiction Clause that precedes a group of state-party mattcrs that fall on what he regards as the permissive side of Article III.

A federal question interpretation of the Court's original jurisdiction requires none of Professor Amar's impressive gymnastics; indeed, it offers a simpler and more satisfying account of original jurisdiction and one that largely comports with Amar's two-tier thesis. For one thing, the text of the Original Jurisdiction Clause quite literally encompasses federal question "cases"-a point that Amar acknowledges. See infra note 240 and accompanying text. For another, a federal question reading explains why the framers incorporated the term "all" with a reference to "those" ("all cases") involving states; they intended to mandate the Court's resolution of federal question claims against the statcs. See infra note 225 . Finally, the federal question reading preserves the framers' important distinction between cases and controversies and avoids Amar's suggestion that the terms must be secn as synonymous.

221. Amar's work draws on so many sources, textual, structural and historical, that it defies casy summation. In brief, he claims that the Constitution requires Congress to structure the federal courts in a way that gives a federal judge the final word on all mandatory-tier "cases": those presenting fcderal questions, coming within admiralty and maritime jurisdiction, and affecting ambassadors. See Amar, supra note 12, at 229-30. Emphasizing the superiority of federal judges to their state counterparts, see Amar, supra note 12, at 233-38; Amar, supra note 220, at 1509-10, and the comparative cquality of all federal judges, see Amar, supra note 12, at 221-22, 254-58; Amar, supra note 220, at 1510, Amar offers a powerful challenge to traditional accounts of the clause as authorizing Congress to fashion exceptions to the Court's appellate jurisdiction. Amar admits that such exceptions may be fashioned, but only if Congress gives other Article III judges the last word on mandatory "cases." See Amar, supra note 12, at 254-59.

222. See Amar, supra note 12, at 240; see also Lawrence G. Sager, supra note 78, at 31-32 (noting that Congress has subtracted both federal question cases and diverse party controvcrsies from the Court's appellate jurisdiction and thus assuming that the constitutional grant encompasses both categories of proceedings). 
menu describes as sucb. Such an interpretation conforms to the framers' understanding that the menu's extension of judicial power to "cases" applied to the subject in dispute and was broad enough to encompass claims involving the states as parties. Thus, the Original Jurisdiction Clause supplies a constitutional basis on which the Court may hear federal claims against the states, thereby perfecting the system of judicial control of state action that the framers consciously wrote into Article III.

This proposed federal question interpretation brings the reach of the Court's original jurisdiction into conformity with the federal focus of the other grants that comprise the Distribution Clause. The grants of original jurisdiction over ambassador and state-party cases vest the Court with original cognizance of the two categories of cases that the framers were unwilling to trust to the state courts under the terms of the Madisonian compromise. ${ }^{223}$ The grant of appellate jurisdiction in "all the other cases" before mentioned-though qualified by the Exceptions and Regulations Clause-is designed to ensure Supreme Court appellate review of state court decisions that implicate the Constitution, laws, and treaties of the United States, as well as of admiralty and maritime decisions. So read, the Distribution Clause corresponds to the Story-Amar thesis ${ }^{224}$ by extending the judicial power "to all Cases." Indeed, the Distribution Clause echoes the preceding paragraph's repetitive use of the term "all," vesting the Court with original jurisdiction in "all" ambassador cases and in "all Cases" involving state parties ${ }^{225}$ and with appellate jurisdiction in "all the other Cases."226

223. Cf. Clinton, supra note 156, at 813-16 (arguing that the Distribution Clause's provision for appellate review ought to be understood to reflect framers' distrust of state courts in the wake of the Madisonian compromise).

224. See supra notes 219-220.

225. In evaluating Professor Amar's argument that the Original Jurisdiction Clause does not provide original jurisdiction in "all" state-party cases, see supra note 220 , consider the text: "In all Cases affecting Ambassadors, ... and those in which a State shall be a Party, the supreme Court shall have original Jurisdiction." U.S. ConsT. art. III, $\S 2, \mathrm{cl}$. 2. Amar claims that the referent of "those" is simply "cases"-a reading that he claims leaves the term "all" out of the state-party grant. See Amar, supra note 12, at 254 n.160; Amar, supra note 10, at 480 . He argues first that an "all cases" reading strains the text. Then, after admitting that "those" can be read to pick up "all cases," he rejects the reading on the "fundamental[ ]" ground of its incompatibility with his theory that "cases" picks up permissive tier matters. See id. at 481 . Thus, the two-tier thesis, and his assumption that state-party cases include only diverse-party disputes, determine his reading of the clause.

Contrary to Professor Amar, I submit that a reading of "those" to encompass "all cases" offers a more natural interpretation of the clause. My claim finds support in the interpolations of Supreme Court Justices, who have for generations rendered the clause in their opinions as if it applied to "all cases." See supra note 178. In addition, such a reading makes the clause consistent with its otherwise mandatory declaration that the Court's original jurisdiction "shall" extend to the cases identified. Indeed, Amar himself has taught us to respect the connection between the framers' use of the term "all" cases in defining a mandatory body of federal judicial power. See supra note 220.

226. Because the Distribution Clause appears to include three references to the term ("all") that supplies the textual key to Amar's theory, I find puzzling Professor Amar's repeated rejection of a federal question reading of the Court's original jurisdiction. See Amar, supra note 12, at 254 n.160; Amar, supra note 10, at $488-90$. Such a reading would apparently perfect the mandatory tier of federal 
The distinction between "cases" and "controversies" also sheds important light on the question whether the State-party Clause extends beyond the federal question and admiralty "cases" literally embraced by its terms. As we liave already seen, the framers understood the broader term "cases" to include the civil controversies that Article III describes as such. That is, one can read the "all Cases" language of the State-party Clause to encompass diverse-party disputes involving the states as well as those that present federal questions. Most observers agree, for example, that the similar reference in the appellate jurisdiction grant to "all the other Cases" encompasses both "cases" and "controversies." 227 It makes little sense, however, to read the State-party Clause to encompass only diverse-party "controversies" and to exclude federal question "cases" from the Court's original docket. Such a reading makes a hash of the framers' apparent understanding by suggesting that state-party "cases" may encompass matters that the menu defines as "controversies" but not those it defines as "cases."228 Yet, paradoxically, the Court itself and most commentators have adopted precisely that reading of the Court's jurisdiction over state-party "cases."229

Apart from its textual problems, the party-alignment orthodoxy rests on the structurally questionable assumption that the framers failed to provide the Court with original cognizance of claims implicating federal limits on state power-those encompassed within "cases" arising under the Constitution - and chose instead to burden the Court, and the parties, with the (relatively) trivial disputes that a "controversies" reading entails. ${ }^{230}$ To

jurisdiction for which Amar contends by assuring the existence of an original tribunal for the assertion of federal question claims against the states. Without sueh an original docket, claims to enforce the Constitution against the states would have been subject to precisely the kind of remedial gap that Amar elsewhere contends his theory closes. See Amar, supra note 12, at 254-57.

227. See, e.g., Amar, supra note 12, at 255; cf. Lawrence G. Sager, supra note 78, at 31-32 (noting that Congress has subtraeted both federal question cases and diverse-party controversies from the Court's appellate jurisdiction and thus assuming that the constitutional grant encompasses both categories of proceedings).

228. For an explicit statement of this position, see id. at 244 n.128; see also WRIGHT \& MILLER, supra note 10, § 3529 (indicating that the "classic" definition of the terms holds that a "controversy" is narrower than a "case" but noting that "nothing has ever been made of the distinction").

229. See supra notes 60,78 and accompanying text.

230. Professor Amar demonstrates quite persuasively that the framers regarded the heads of federal question, admiralty, and ambassador jurisdiction as more central to the constitutional plan than diverseparty heads of jurisdiction. See Amar, supra note 12, at 246-54; Amar, supra note 220, at 1508. But see Holt, "To Establish Justice," supra note 51, at 1458-59 (arguing for the centrality of diverse party claims in the thinking of the framers). I thus have difficulty understanding Amar's claim that the framers deliberately vested the Court with original cognizance of matters that he clearly regards as dispensable. Indeed, under Amar's reading, the framers assigned the Court original cognizance (in apparently mandatory language) of fully half of the diverse-party controversies that fall within his permissive tier.

Amar solves the problem (as far as he is concerned) by treating these matters as subjeet to congressional exceptions, a move that permits him to argue that Congress can alleviate the Court's burden. See Amar, supra note 12, at 254 n.160; Amar, supra note 10, at 478-88. For the vast majority of scholars who continue to view the Court's jurisdiction as mandatory, the traditional reading appears to burden the Court with the resolution of diversity disputes, but to deny it jurisdiction over federal 
be sure, the grant of power over "controversies between two or more states" has been widely viewed as involving disputes of the kind that may have been thought to deserve original Supreme Court resolution. ${ }^{231}$ But as the drafting history and the comments of St. George Tucker make clear, many interstate disputes were thought to present federal questions, and therefore to fall within the grant of original jurisdiction over "cases" arising under the Constitution in which state parties appear. ${ }^{232}$ In any case, the framers understood that the provision for jurisdiction over other "controversies" involving states would encompass other, less important issues. ${ }^{233}$ It seems unlikely that the framers would have compelled the Court to hear only such "controversies" and have deprived it of cognizance in federal question disputes.

The orthodox reading also suffers structurally from its failure to account for the framers' omission of clains involving foreign nations from

question cases. Such an allocation makes little sense today, as I argue later, and seems difficult to square with the framers' concem with securing the supremacy of federal law.

231. See WARREN, supra note 105, at 34-35; Rhode Island v. Massachusetts, 37 U.S. (12 Pet.) 657, 720 (1838) (tracing the history of the "controversies between two or more states" grant, and deeming the grant essential to the constitutional plan).

232. St. George Tucker believed that territorial disputes arose under the Constitution; he argued that federal jurisdiction over "cases" arising under the Constitution would encompass disputes between the states as well as those between citizens of the same states claiming lands under grants from different states. See 1 Blackstone, supra note 89 , app. at 404.

The drafting history of Article III suggests that the framers may have regarded the addition of "cases arising under the constitution" as encompassing virtually all federal question disputes between the states, including those involving territory and jurisdiction. As reported out of the Committee of Detail, the Constitution assigned responsibility for settling territorial disputes to the Senate in language that tracked the Articles of Confederation. See 2 Records of the Federal Convention, supra note 77, at 183-85 (setting forth terms of Senate's power to resolve disputes between states respecting "jurisdiction or territory"); supra note 114 (describing a similar provision in the Articles of Confederation). See generally WARREN, supra note 105 (describing operation of interstate dispute resolution under the Articles). Accordingly, the Committee draft of Article III's provision for cognizance of controversies between two or more states specifically excepted "such as shall regard Territory or Jurisdiction." 2 Records of THE FEDERAL Convention, supra note 77, at 186 . The convention decided to shift this power from the Senate to the federal judiciary and thus deleted the Senate provision on August 24. See id. at 396, 400-01 (reporting approval of Rutledge's motion to strike Senate provision on the ground that it had been "rendered unnecessary by the National Judiciary now to be established").

When the convention tumed to the judiciary article three days later (on August 27), its members voted to add "cases" arising under this Constitution to the subjects of federal judicial cogmizance. See infra note 272 and accompanying text. As noted later in this Article, such an addition to the existing grant of original jurisdiction over state-party "cases" authorized the Court to entertain all interstate disputes that presented federal questions. See infra notes $274-75$ and accompanying text. It may well be that this addition was thought to supply the vehicle for hearing territorial disputes between the states that had been stripped from the Senate - for the convention failed to strike the exception for territorial disputes from the "controversy" grant until the Committee of Style report on September 12. See 2 ReCords of the Federal Convention, supra note 77, at 600 .

233. Certainly "controversies" between a state and the citizens of another state present the sorts of non-federal disputes that do not appear to require a federal docket. Recall that most observers believed that states could appear as plaintiffs in other states' courts, notwithstanding the grant of original jurisdiction. See supra note 41 . 
the Court's Original Jurisdiction Clause. ${ }^{234}$ Traditionalists argue that the Court's original jurisdiction was meant to provide a forum with a weight and dignity suitable for hearing claims that involve other sovereigns, such as the states themselves and ambassadors representing foreign countries. ${ }^{235}$ Why, then, did the framers fail to provide a similar forum for claims involving foreign nations? The franiers included such claims on the jurisdictional menu as party-based "controversies," reflecting their perception that foreign nations could bring or defend common law property and contract claims in federal court. Claims involving foreign nations do not, however, appear in the Original Jurisdiction Clause. ${ }^{236}$

While the traditional reading of the Distribution Clause cannot explain this omission, it makes perfect sense in a clause that refers to "cases" and thus deals primarily with the enforcement of federal law. ${ }^{237}$ The framers had little reason to expect that the Constitution, laws, and treaties of the United States would impose on foreign nations obligations that would be proper subjects for federal question jurisdiction. Foreign nations were not, of course, bound by the Federal Constitution and laws in a legal sense as the states were under the Supremacy Clause; the enforcement of such nations' treaty obligations was understood to require negotiation and, perhaps, the implicit threat of war. ${ }^{238}$ The failure of the Original Jurisdiction Clause to include those disputes in which foreign countries were parties is further evidence that the framers conceived of the grant as embracing federal questions. Thus, the conception of the Court's original docket as driven by concerns stemming from the doctrines of sovereign immunity under the law of

234. An early draft of section 13 of the Judiciary Act empowered the Court to hear originally "controversies of a "civil' nature" involving not only the states themselves, but also foreign state parties. See Jultus Goebel, JR., ANTECEdennts ANd Beginnings to 1801, at 477 (The Oliver Wendell Holmes Devise History of the Supreme Court of the United States, vol. 1, Paul A. Freund ed., 1971). Although Professor Goebel does not reveal whether the records disclose a rationale for the eventual deletion of the foreign-state party provision from the final text of the Act, 1 find the appearance of the provision suggestive. The Act generally followed a "controversies" reading of the Original Jurisdiction Clause, see supra notes 76,78 ; the draft described by Goebel thus serves to confirm my suggestion that foreignstate controversies were logical candidates for inclusion in such a "controversies"-oriented provision.

235. See supra notes $15-23$ and accompanying text.

236. It is, of course, possible that the Court could hear such claims under the traditional reading of the Distribution Clause, but only if they involved a state as the opposing party.

237. The geographic logie that, according to Professor Amar, underlies the Court's Original Jurisdiction Clause would seem to argue for the assignment of disputes involving foreign nations to the Court's original docket. For a description of Amar's geographic argument, see supra notes 43-56, infra note 381 and accompanying text. Surely we would expect to find representatives of foreign nations in close proximity to the physical center of the federal government, just as Amar argues we could expect to find state representatives and ambassadors there. Yet tbe authors of Article III declined to assign foreign nation disputes to the Court's original docket, just as they refrained from giving the Court original cognizance of cases involving the United States as a party.

238. See supra note 105 . 
nations offers a cogent explanation of the inclusion of state parties and the exclusion of the United States and foreign nations. ${ }^{239}$

Even Professor Amar does not really take issue with the claim that the Original Jurisdiction Clause literally embraces federal question claims involving state parties; indeed, he admits that a federal question reading "might seem to reflect better the actual text" of the clause. ${ }^{240}$ To be sure, Amar quibbles with a literal reading on the ground that it produces the "autistic" result of extending the Court's jurisdiction to non-federal disputes between a state and its own citizens. ${ }^{241}$ But the literal reading does not produce such "autism" once we recognize, as Amar later points out, that the clause has to be read with reference to the jurisdictional menu. ${ }^{242}$ Since non-federal disputes between a state and its own citizens do not so appear, they cannot be incorporated in the Original Jurisdiction Clause and Amar's "autistic" result disappears.

It thus appears that the federal question reading of the Original Jurisdiction Clause proposed here outperforms the orthodox party-alignment account. The former account better fits the literal terms of the clause's reference to "cases" by sweeping in both the federal question and admiralty cases that the menu describes as such and the party-alignment "controversies" that involve state parties. This literal interpretation also makes more structural sense than the orthodox view, which leaves federal law limits on state action beyond the reach of the Court's original jurisdiction. Finally, a literal account explains the inclusion of state-party cases and the exclusion of those involving the Umited States and foreign nations on grounds of sovereign immumity: the framers were willing to establish a constitutionally mandated forum for the resolution of claims against the states but not for claims against other sovereigns.

\section{IV}

\section{Original Jurisdiction Before the Convention and the States: The Drafting History and the Ratification Debates}

As argued in the previous Parts, the grant of original jurisdiction over state-party cases deserves on both structural and textual grounds to be viewed as an essential element in the framers' plan to ensure that federal law, within its proper bounds, would bind the states in their corporate capacity. Such an understanding certainly emerges from a review of the

239. As for the states, the framers sought to assure the existence of an original tribunal for coercive claims against the states in order to overcome sovercign immunity under the law of nations. See supra notes 84-131 and accompanying text. By contrast, I argue that the United States was omitted from the Court's original cognizance to leave to Congress' discretion the scope of federal government immunity from suit in its own courts. See infra notes 283-87, 406-14 and accompanying text.

240. See Amar, supra note 10, at 489.

241. Id. at 488-89.

242. See id. at 489. 
framers' drafts of and debates concerning Article III at the convention and from later discussions of the article in the ratification debates. In this Part, I review the high points of this much bruited and misunderstood history.

\section{A. Original Jurisdiction in the Committee of Detail}

The Original Jurisdiction Clause as we now know it first appeared in a late draft of Article III by the Committee of Detail at Philadelphia ${ }^{243}$ and changed remarkably little over the course of the convention's subsequent deliberations. ${ }^{244}$ Drafted by James Wilson, the clause conferred jurisdiction on the Court to hear originally ambassador cases, state-party cases, and impeachments. ${ }^{245}$ The power to try impeachments was later transferred to the Senate, ${ }^{246}$ but the two remaining grants of original jurisdiction survived essentially as Wilson wrote them. A variety of factors suggest that the paramount purpose of the state-party grant was to secure an original docket for the assertion of coercive federal claims against the states, on the theory that the Court's appellate jurisdiction was inadequate to overcome the difficulties posed by state sovereign immunity and the Madisonian compromise. ${ }^{247}$

243. The Committee of Detail, appointed on July 24, included James Wilson, Edmund Randolph, John Rutledge, Oliver Ellsworth, and Nathaniel Gorham. It was charged with reporting to the full convention a constitution that conformed to the resolutions passed by the convention in the preceding weeks. See 2 Records of the Federal Convention, supra note 77, at 97, 106; Goebel, supra note 234, at 232.

244. For purposes of understanding the evolution of the judiciary department bcfore the Committee of Detail, scholars agree that the two most important drafts of Article III were those preparcd by Edmund Randolph, 2 ReCords of the Federal Convention, supra note 77, at 137, and by James Wilson, 2 id. at 163; see also Amar, supra note 12, at 243-44; Clinton, supra note 156, at 772-86. As Farrand reports, the Randolph draft bears check marks by each item that was incorporated into later drafts. See 2 Records of the Federal Convention, supra note 77, at 137 n.6.

245. The Wilson draft of what later became Article III, Section 2, provides as follows:

The Jurisdiction of the Supreme (National) Court shall extend to all Cascs arising under Laws passed by the Legislature of the United States; to all Cases affecting Ambassadors (and other) <other > public Ministcrs <\& Consuls>, to the Trial of Impeachments of Officers of the United States; to all Cases of Admiralty and Maritime Jurisdiction; to Controvcrsies between $<$ States, - except those wh. regard Jurisdn or Tcritory,-betwn $>$ a State and a Citizen or Citizens of another State, between Citizens of different States and between <a Stafe or the> Citizens (of any of the States) <thereof> and foreign States, Citizens or Subjects. In Cases of Impeachment, (those) <Cases> affecting Ambassadors (and) other public Minisfers <\& Consuls $>$, and those in which a State shall be (one of the) $\langle a\rangle$ Part(ies) $<y\rangle$, this Jurisdiction shall be original. In all the other Cases beforementioned, it shall be appellate, with such Exceptions and under such Regulations as the Legislature shall make. The Legislature may (distribute) <assign any part of $>$ th(is)e Jurisdiction <above mentd.,-exccpt the Trial of the Executive $\longrightarrow$, in the Manner and under the Limitations which it shall think proper (among) $<$ <o> such (other) <inferion Courts as it shall constitute from Time to Time.

2 Records of tHe Federal Convention, supra note 77, at 172-73. The draft appears in Wilson's hand; parts in parentheses were marked out in the original draft; those in angle brackets were added by Rutledge. Id. at 163 n.17. The Committee of Detail's final draft as reported to the convention, was essentially identical to Wilson's draft, as edited by Rutledge.

246. For a full account of the handling of impeachments, describing their initial assignment to the judiciary and later transfer to the House and Senate, see WARREN, supra note 83, at 658-64.

247. For further discussion of this argument, see supra notes 169-74 and accompanying fext. The link between the Court's original jurisdiction and the Madisonian compromise comes through a consideration of the various plans of the Constitution that the Committee of Detail considered in piecing 
It is significant that Wilson wrote the grant of state-party original jurisdiction into Article III. ${ }^{248}$ Dedicated to a strong national government, Wilson was well aware of the doctrine of sovereign immunity and committed to restricting its application in America. ${ }^{249} \mathrm{He}$ not only played a central role in drafting language for the Pennsylvania constitution that abrogated sovereign immunity ${ }^{250}$ but also argued persuasively in Chisholm and in his lectures on law that the British doctrine of immunity had no place in the United States government. ${ }^{251}$ In addition, it was Wilson who had represented Simon Nathan in his unsuccessful suit against Virginia in a Pennsylvania court. 252

At least two of the remaining four members of the Committee of Detail, Edmund Randolph and Oliver Ellsworth, shared Wilson's view that the Original Jurisdiction Clause had been drafted to authorize suits against the states. Like Wilson, Randolph had been intimately involved in the disposition of Nathan's claim against Virginia. ${ }^{253}$ Randolph's understanding of the Original Jurisdiction Clause is evident both in his comments to the Virginia ratification convention ${ }^{254}$ and in his subsequent report to Congress on proposed changes to the Judiciary Act of $1789 .{ }^{255}$ Ellsworth drafted

together its draft of Article III. The Randolph plan mandated the creation of lower federal courts; it therefore did not provide the Court with any original jurisdiction. See 1 Documentary History of THE Constrtution, supra note 109, at 244-45. By contrast, the Pinckney and Paterson plans, each of which contemplated Supreme Court review of state court decisions and no constitutionally compelled inferior federal courts of general jurisdiction, both contained provisions for original Supreme Court cognizance of certain causes of action. See id. at 247 (reprinting Pinckney plan) (providing for institution of lower federal courts of admiralty, but otherwise contemplating appellate review of state court decisions; vesting Court with original cognizance of impeachments and cases affecting ambassadors and public ministers); id. at 252 (reprinting Paterson plan) (not providing for inferior federal courts, but instead contemplating appellate review of state court decisions; giving the Supreme Court original cognizance of impeachments); see also Engdahl, supra note 83, at 484-85 (linking the Wilson draft in the committee of Detail to the Paterson plan). As Hart and Wechsler justly observe, after "it had been decided that the creation of inferior courts should be at the discretion of Congress, the Supreme Court's original jurisdiction took on new importance as the only available means of assuring access to a federal tribunal." HaRT \& WEChSLER, supra note 10 , at 18.

248. Cf. Clinton, supra note 150, at 1521 ("Justice Wilson ... had the greatest reason to know the originally intended meaning of Article III of any Supreme Court justice...."). He was viewed by his colleagues as one of the most able lawyers at the convention, see, e.g., William Rawle, Chancellor of the Association of the Bar of Philadelphia, Address to the Members (1824), in 10 HazArD's Register of PenNsylvania 290-91 (1832) (describing Wilson "in the splendour of his talents, and the fulness of his practice"), and many historians regard his contributions to the final plan of government as second in importance only to those of Madison, see, e.g., FARRAND, supra note 132, at 197.

249. See JENSEN, supra note 132, at 26 (describing Wilson's consistent arguments for expanded national sovereignty and his opposition to the affirmation of retained state sovereignty in the Articles of Confederation).

250. See supra note 121.

251. See supra note 93.

252. See supra note 120 and accompanying text.

253. See supra note 126.

254. See infra notes $338-48$ and accompanying text.

255. See infra note 338 . 
section 13 of the Judiciary Act ${ }^{256}$ - a provision that, for all its flaws, gave the Court original cognizance of suits against the states.

A comparison between Wilson's draft and the preceding draft of Article III also provides insight into the Original Jurisdiction Clause. The earlier draft by Randolph had conferred appellate jurisdiction on the Court to hear all cases within the federal judicial power and had provided, in keeping with the Madisonian compromise, that Congress would have power to assign such jurisdiction to the lower federal courts. ${ }^{257}$ In contrast to the Wilson draft, the Randolph draft had conferred original jurisdiction on the Court only in cases of impeachment "and in those instances in which the legislature shall make it original."258 It did not specifically confer any constitutional source of original jurisdiction on the Court in either ambassador or state-party cases.

What moved the Committee to add original jurisdiction to the Wilson draft? One can speculate that the members of the Committee decided, upon reflection, that the Randolph draft had relied too heavily on the state courts as courts of first instance. The progression of the drafts, from one that vested all original jurisdiction in state courts to one that conferred original jurisdiction directly upon the Court, thus offers support for the claim that the grant was predicated on distrust of state courts and a preference for original cognizance in the federal courts.

The drafting history of Article III's grant of original jurisdiction also reveals that the framers did not intend for the grant to preclude Congress from vesting the lower federal courts with concurrent jurisdiction over matters that the Constitution had assigned to the Court's original docket. The Court eventually came to this conclusion in Börs v. Preston-thus abandoning an important implication of Marshall's dicta in Marbury. ${ }^{259}$ The

256. See Goebel, supra note 234, at 477 (discussing the Committee of Detail's drafting of section 13); Engdahl, supra note 83, at 494 (discussing Ellsworth's principal role in drafting the Judiciary Act).

257. The Randolph draft provides as follows:

7. The jurisdiction of the supreme tribunal shall extend

1. to all cases, arising under laws passed by the general <Legislature>

2. to impeachments of officers, and

3. to such other cases, as the national legislature may assign, as involving the national peace and harmony, in the collection of the revenue in disputes between citizens of different states <in disputes between a State \& a Citizen or Citizens of another State> in disputes between different states; and in disputes, in which subjects or citizens of other countries are concemed $<\&$ in Cases of Admiralty Jurisdn $>$ But this supreme jurisdiction shall be appellate only, except in $<$ Cases of Impeachmt. \& (in) $>$ those instances, in which the legislature shall make it original. and the legislature shall organize it

8. The whole or a part of the jurisdiction aforesaid aecording to the discretion of the legislature may be assigned to the inferior tribunals, as original tribunals.

2 ReCords of the Federal Convention, supra note 77, at 146-47 (footnote omitted). Parts in parentheses were crossed out; parts in angle brackets were added by Rutledge.

258. Id. at 147.

259. See Börs v. Preston, 111 U.S. 252, 258-59 (1884) (diverging from the implication of Marshall's opinion that the Constitution provides the Supreme Court with exclusive jurisdiction of all cases over which it has original jurisdiction). 
drafting history bears out the Börs Court's conclusion. Early drafts of Article III, ${ }^{260}$ as well as the final report of the Committee of Detail, expressly provided that Congress could assign "any part of the jurisdiction above mentioned (except the trial of the President of the United States) in the manner, and under the limitations which it shall think proper, to such Inferior Courts, as it shall constitute from time to time."261 Although the "Assignment Clause" was later stricken from Article III as redundant, the clause indicates that the framers meant to leave Congress free to authorize the lower federal courts to exercise concurrent original jurisdiction in ambassador and state-party cases even though these heads of jurisdiction had been constitutionally vested in the Supreme Court. ${ }^{262}$

260. See supra notes 245,257 (setting forth the terms of clauses in the Wilson and Randolph drafts that authorized Congress to assign the jurisdiction of the Court to inferior tribunals).

261. 2 ReCORDS OF tHE Federal CONVENTION, supra note 77, at 186-87. The full text of the final Committee of Dctail draft of what became Article III, $\S 2$ reads as follows:

The Jurisdiction of the Supreme Court shall extend to all cases arising under laws passed by the Legislature of the United States; to all cases affecting Ambassadors, other Public Ministers and Consuls; to the trial of impeachments of Officers of the United States; to all cases of Admiralty and maritime jurisdiction; to controversies between two or more States, (except such as shall regard Territory or Jurisdiction) between a State and Citizens of another State, between Citizens of different States, and between a State or the Citizens thereof and foreign States, citizens or subjects. In cases of impeachment, cases affecting Ambassadors, other Public Ministers and Consuls, and those in which a State shall be party, this jurisdiction shall be original. In all the other cases before mentioned, it shall be appellate, with such exccptions and under such regulations as the Legislature shall make. The Legislature may assign any part of the jurisdiction above mentioned (except the trial of the President of the United States) in the manner, and under the limitations which it shall think proper, to such Inferior Courts, as it shall constitute from time to time.

Id.

262. Although Professor Goebel expressed some doubts on the question, see Goebel, supra note 234, at 243 n.228, most observers agree that the Assignment Clause was stricken from Article III on August 27 on grounds of redundancy. See, e.g., HART \& WeChSLER, supra note 10, at 11-12 \& n.46; Clinton, supra note 156, at 792-93. An examination of the events leading up to the motion to strike, which was adopted unanimously, certainly bears out the predominant view. As reported to the convention, Article III first provided for the vesting of the judicial power in the Supreme Court and in such infcrior courts as Congress might ordain and establish. 2 ReCords OF THE FEDERAL Convention, supra note 77, at 186-87. It then described the "jurisdiction" of the Supreme Court, listing the various cascs and controversies that now make up Seetion 2. Finally, it provided in the Assignment Clause that Congress could assign the Court's "jurisdiction" to inferior federal courts (except impeachments). See id. Provisions of Article I already provided Congress with the power to constitute tribunals inferior to the Supreme Court and to make all laws neeessary and proper for carrying into effect the powers of any dcpartment of the new government. See id. at 182 .

Deletion of the Assignment Clause was precipitated by Madison's and Governor Morris's motion to change the words "jurisdiction of the Supreme Court" in the description of federal proceedings to "judicial power." Acceptance of this motion, see id. at 431 , meant that if Congress chose to create infcrior federal tribunals, the tribunals could exercise any kind of "judicial power," described in Article III, that Congress chose to confer upon them. Coupled with the Necessary and Proper Clause, the existence of provisions that clearly authorized lower federal courts to exercise "judicial power" made the Assignment Clause unnecessary. That the change was merely technical, and not designed to alter the power of Congress to allocate jurisdiction between the Supreme Court and inferior courts finds further support in the delegates' unanimous support for the change, see id. (reprinting Madison's journal) (recording an 8-0 vote for deletion), since substantive changes to the same clause on that same day produced divisions. 
The Committee of Detail's proposed Assignment Clause thus offers important evidence that the grant of original jurisdiction over ambassador and state-party cases was not grounded in distrust of the lower federal courts per se. Except for impeachment trials, which had been assigned exclusively to the Court's original docket before their transfer to the Senate, the Assignment Clause authorized Congress to permit lower federal courts to hear disputes that came within the Court's original jurisdiction. As a historical matter, therefore, one finds little evidence that, outside the special case of impeachments, the Committee of Detail envisioned the Court as a "dignified" tribunal with a unique role to play in original disputes. Rather, the Committee seems to have acted on the basis of distrust of the state courts. ${ }^{263}$

\section{B. Original Jurisdiction Before the Convention}

As reported out of the Committee of Detail, the system for ensuring federal control of state action was only partially in place. Although the grant of original jurisdiction encompassed state-party "cases," the jurisdictional menu included only three categories of such cases: those arising under laws passed by Congress, those of admiralty and maritime jurisdiction, and those iuvolving impeachments. ${ }^{264}$ The Supremacy Clause suffered from one of the same flaws; while it declared federal treaties and laws binding on the states, it failed to include a similar declaration as to the Constitution itself. ${ }^{265}$ The plan thus lacked a mechanism for assuring state compliance with the constitutional limitations on state power enumerated in the committee draft. ${ }^{266}$

263. Cf. Engdahl, supra note 83, at 477 ("There were some matters that seemed clearly inappropriate for state court adjudication."). For a telling suggestion that the Court's grant of original jurisdiction necessarily operated to deprive Congress of the power of assigning such matters to the state trial courts, see Letter from Fisher Ames to John Lowell (July 28, 1789), in 4 DOCUMENTARY HistorY OF THE SUPREME COURT, supra note 41, at 480, 481 ("Some persons have proposed that the Jurisdiction of the Federal Judicial should be merely appellate and that the State Courts should hold cognizance of all Causes, those specially assigned to the original jurisdiction of the Supreme Court by the Constitution excepted.").

264. See 2 Records of the Federal Convention, supra note 77, at 186-87. It also included ambassador cases, but these were the subject of an independent grant of original jurisdiction.

265. The text of the Supremacy Clause, as reported by the Committee of Detail, read as follows:

The Acts of the Legislature of the United States made in pursuance of this Constitution, and all treaties made under the authority of the United States shall be the supreme law of the several States, and of their citizens and inhabitants; and the judges in the several States shall be bound thereby in their decisions; anything in the Constitutions or law of the several States to the contrary notwithstanding.

Id. at 183 .

266. The Committee of Detail's draft included provisions absolutely barring the states from coining money, granting letters of marque and reprisals, entering into treaties, alliances and confederations, and granting titles of nobility. See id. at 187 . It also contained provisions similar to those finally adopted that barred states, without congressional consent, from emitting bills of credit, laying duties on imports, and entering into interstate compacts or agreements. Id. 
The convention cured the first of these flaws on August 23 when it approved Rutledge's proposed amendment that added "this Constitution" to the texts made binding on states through the Supremacy Clause. ${ }^{267}$ This reconsideration of the Supremacy Clause, which the convention by now associated with the control of state action, called forth a final effort to pass a congressional negative on state laws. ${ }^{268}$ Madison and Wilson spoke warmly in favor of the proposal, ${ }^{269}$ as they had from the beginning, but it was defeated by a single vote. ${ }^{270}$ In the end, the convention cast its lot with judicial, rather than legislative, control of the states.

Four days later, the convention took up the judicial branch of the government, seeking initially to broaden the scope of judicial power. ${ }^{271}$ On motion by Dr. William Samuel Johnson of Connecticut, the convention agreed to extend the judicial power to all cases "both im law and equity."272 Also on Johnson's motion, it extended the judicial power to "cases" arising under the Constitution and treaties. ${ }^{273}$ Finally, the convention reworked the language of Article III to extend the judicial power to cases arising under the laws of the United States, instead of limiting the grant to laws "passed by the Legislature" as the Committee report had provided. ${ }^{274}$ Taken together, these changes expanded the judicial power generally, and made it essentially coextensive with the language of the Supremacy Clause.

This was heady stuff. The implications of placing cases arising under the Constitution within the judicial power were not lost on the convention. In a widely quoted argument, Madison expressed concern with the potential

267. See id. at $381-82,389$. The significance of the amendment to the Supremacy Clause was not lost on the participants in the convention. Luther Martin, who led Maryland's opposition to the ratification of the Constitution, began to hold meetings in the evenings with such other prominent fencesitters as George Mason and Elbridge Gerry. The object of these meetings, as Martin later explained, was "to protect and preserve, if possible, the existence and essential rights of all the States." WARREN, supra note 83 , at 521 .

268. Madison reports that Pinckney made the motion to broaden the legislature's powers to include a power to "negative all laws passed by the several States interfering in the opinion of the Legislature with the General interests and harmony of the Union." 2 ReCORDS OF THE FEDERAL CONVENTION, supra note 77 , at 390 .

269. Madison described himself as a friend to the proposal "from the beginning"; Wilson thought it the "key-stone wanted to compleat the wide arch of Government we are raising." Id. at 390-91. Yet Rutledge and Ellsworth-and to a lesser degree Mason-all spoke out against the proposal and its commitment to committee was defeated by a single vote. Id.

270. Id. at 391.

271. The convention's work on that day deserves special attention, both beeause it offers insights into the views of the delegates towards the Court's original jurisdiction and beeause the events were transcribed by Madison in an uncharacteristically incomplete manner. Indeed, the Court's original docket played a far more central role in the deliberations of August 27 than has beeu recognized heretofore.

272. 2 ReCords of the Federal Convention, supra note 77, at $422,428$.

273. Id. at $423-24,430$.

274. Id. at $423-24,431$; see also id. at 186 (reprinting text of original Committee draft). 
breadth of the Court's power to hear cases arising under the Constitution..$^{275}$ As Madison's journal reports:

Mr Madison doubted whether it was not going too far to extend the jurisdiction of the Court generally to cases arising Under the Constitution, \& whether it ought not to be limited to cases of a Judiciary Nature. The right of expounding the Constitution in cases not of this nature ought not to be given to that Department.

The motion of Docr. Johnson was agreed to nem: con: it being generally supposed that the jurisdiction given was constructively limited to cases of a Judiciary nature . . . 276

Madison's expression of concern has been thought to offer the convention's clearest statement of the modern "case or controversy" limitation on the power of federal courts to render decisions on constitutional questions. ${ }^{277}$ But most observers have failed to perceive that the statement may also reflect Madison's assumption that the Court's original jurisdiction would extend to such "cases" under the terms of the Original Jurisdiction Clause.

It is unlikely that Madison would have worried that a grant of appellate jurisdiction over cases arising under the Constitution would authorize the Court to "expound[] the Constitution" outside the context of a litigated case. By its nature, the Supreme Court's appellate jurisdiction would operate on cases that had been previously decided by either the state courts (exercising common law jurisdiction) or the lower federal courts under enabling legislation from Congress. In most such cases, actual disputes would have been presented by the parties and adjudicated in accordance with law before they reached the Court. The grant of appellate jurisdiction over constitutional cases thus did not present the prospect of a judiciary exercising a "general[ ] jurisdiction" over state compliance with constitutional limits. ${ }^{278}$

275. Charles Warren, for example, features Madison's comment quite prominently in his discussion of the work of the convention on August 30. As Warren interprets it, Madison's remark settles the principle that

under our Government, the Court only decides cases; it does not decide questions. It has no power to act, until there is at issue before it a litigated case, in which there are two adversary parties, each contending for a legal right.

WARREN, supra note 83 , at 541 .

276. 2 Records of the Federal Convention, supra note 77 , at 430 .

277. See Clinton, supra note 156, at $788-90$ (arguing that the convention's acceptance of Madison's argument underlies current standing, mootness, and ripeness doctrines).

278. Of course, at the time Madison spoke, some state courts were willing to issue advisory opinions in disputes that did not conform to the modern "case or controversy" rule. See Fletcher, supra note 207, at 267-68. Yet such cases were sufficiently unusual to have had little bearing on Madison's argument.

To be sure, Madison's comment contemplates the application of "case or controversy" limits to both the Supreme Court and lower federal courts. But Madison specifies an existing grant of jurisdiction to the Court in Article III (and not the prospect that lower federal courts will exercise arising-under jurisdiction on a grant from Congress) as the cause of his concern. Madison's comments thus locate his concern in the Distribution Clause and its jurisdictional grants to the Court. Of the two grants, the Original Jurisdiction Clause appears the more likely target of Madison's concern. The 
What Madison may have feared was the assertion of original jurisdiction over such claims, particularly injunctive claims, and the consequent effect of vesting control of the states in the judicial rather than the legislative branch. Note in particular Madison's suggestion that the error lay not in providing the federal government with a general negative on unconstitutional state laws but on the apparent operation of Article III to vest that negative in the "Judiciary Department." Madison thus argued not against the wisdom of a negative-after all, he had long championed the congressional negative on state laws. ${ }^{279}$ Rather, he argued against the assignment of a general negative to the Court's original docket. If the Court adopted a broad view of its original jurisdiction-one not informed by an understanding that its power was constructively limited to cases of a "judiciary nature"-it might well exercise a broad negative on state laws similar to the one Madison and others had sought to confer on Congress.

Support for this interpretation of Madison's comments can be found in Edmund Randolph's stated reasons for initially opposing the Constitution. Although he later supported ratification (with amendments) in the Virgima debate, Randolph had grown disenchanted with the direction of the convention and had refused to sign the final document. ${ }^{280}$ This refusal rested in part on the perceived vagueness and generality of the extension of judicial power over cases arising under the Constitution. ${ }^{281}$ Randolph was a well-

appellate jurisdiction of the Supreme Court was subject to exceptions and regulations of Congress. Inferior federal courts would only exercise that jurisdiction which Congress conferred upon them. In view of the framers' attitude that Congress might be too quick to curtail a judicial negative on state action, see supra note 162 and accompanying text, it secms unlikely that Madison would have worried that Congress would extend the judicial negative to lower federal courts outside the context of litigated disputes. Instead, he was likely concerned with the single, apparently uncontrollable grant of "arising under" jurisdiction in Article III-the grant of original jurisdiction in state-party cases.

279. See supra note 269 and accompanying text.

280. Note, for example, Randolph's comment during debates over the regulation of trade: "that there were features so odious in the Constitution as it now stands, that he doubted whether he should be able to agree to it." 2 ReCORDS OF THE FEDERAL CONVENTION, supra note 77, at 452 . For an account of his refusal to sign, see WARREN, supra note 83 , at 714-15.

281. Randolph offered a general account of his refusal to sign in a letter that he released for publication as a pamphlet. See Letter from Edmund Randolph (Oct. 10, 1787), in 2 ThE Complete ANTI-FEDERALIST, supra note 50, at 83, 83-98. In this account, he identified the convention's passage of resolutions forbidding state ratification delegations to amend the convention's draft as the principal basis for his decision, id. at 95-96, but also noted a variety of amendments that deserved consideration, $i d$. at 96-97. In particular, he noted the vagueness of the judiciary article. See id. at 97 (expressing hope that Virginia's proposed amendment, which suggested "limiting and defining the judicial power" be accepted by a majority of the states). Randolph returned to this subject in the debates at the Virginia ratifying convention where he supported ratification with amendments. He expressed his concerns as follows:

It is ambiguous in some parts, and unnecessarily extensive in others. It extends to all cases in law and equity arising under the Constitution. What are these cases of law and equity? Do they not involve all rights, from an inchoate right to a complete right, arising from this Constitution? Notwithstanding the contempt gentlemen express for technical terms, I wish such were mentioned here. I would have thought it more safe, if it had been more clearly expressed. What do we mean by the words arising under the Constitution? What do they relate to? I coneeive this to be very ambiguous. If my interpretation be right, the word arising will be carried so far that it will be made use of to aid and extend the federal jurisdiction. 
informed member of the Committee of Detail and understood that the combination of the "Arising Under" and Original Jurisdiction Clauses conferred broad and somewhat open-ended powers on the Court to check state action. ${ }^{282}$ The mandatory character of the Court's original jurisdiction, moreover, suggested that the Court would perform this checking function without legislative control.

The remaiming work of the convention on August 27 underscores the importance of the Court's original jurisdiction in the framers' deliberations about judicial power. It also lends some support to the claim that concerns about original jurisdiction triggered Madison's expression of concern. Unfortunately, these deliberations were omitted from Madison's journal, so we must reconstruct the tenor of the discussions from the scant evidence in the official journal. The first proposed amendment to the Original Jurisdiction Cláuse would have extended the Court's original docket to cases in which the United States appeared as a party. ${ }^{283}$ It was adopted by the convention shortly after cases arising under the Constitution were added to the judicial power. ${ }^{284}$ Then, an abrupt change of heart took place. The convention first considered a proposal that would have declared much original jurisdiction vested in the courts of the several states, subject only to an appeal to federal courts. ${ }^{285}$ After withdrawing this proposal, the convention voted to return to the text of the Original Jurisdiction Clause as reported by the Committee, thereby omitting U.S.-party cases from the Court's original docket. $^{286}$

3 Elliot's Debates, supra note 50, at 572 (remarks of Edmund Randolph); see also id. at 602 (indicating that if he "were to propose an amendment [to Article III], it would be to limit the word arising"). One can understand Randolph's concern as expressing the fear that the judiciary would create new implied rights of action against the states, rights not expressly contained in the direct prohibitions on state action that were understood as the core of the arising-under grant, and thus broaden the scope of national power. Given Randolph's understanding that the Court's original jurisdiction cncompassed federal question claims against the states, see infra notes 334-48 and accompanying text, we can locate this concern as one stemming from the scope of the Court's mandatory grant of original jurisdiction.

282. See infra notes $334-48$ and accompanying text.

283. 2 Records of the Federal Convention, supra note 77, at 424.

284. See id. at 423-24.

285. Under the proposed amendment, the Distribution Clause would have read as follows: "In all the other cases beforementioned original jurisdiction shall be in the Courts of the several States but with appeal both as to Law and fact to the courts of the United States, with such exceptions and under such regulations, as the Legislatures shall make." Id. at 424 . I read the amendment as a substitute for the Distribution Clause's provision for the Court's exercise of appellate jurisdiction-one that would have left the Court's two grants of original jurisdiction intact. Such an amendment would have precluded Congress from broadening the Court's original docket and from giving the lower federal courts original cognizance of any cases other than those already assigned to the Court. A similar proposed amendment surfaced in the Virginia ratification convention. See infra note 333.

286. See 2 Records of the Federal Convention, supra note 77, at 424. Later, however, an amendment was proposed to declare that "in cases in which the United States shall be a Party the jurisdiction shall be original or appellate as the Legislature may direct." Id. The amendment was weakened by the elimination of the reference to original jurisdiction, however, and then defeated by a vote of 5-3. Id. at 424-25. The Constitution thus lacks any mandatory source of jurisdiction over claims 
Although the precise reasons for this dramatic change remain obscure, one plausible reason involves concerns about the scope of governmental immunity. The addition of U.S.-party cases to the Court's original docket brought claims both by and against the Umited States within the mandatory scope of the Court's original cognizance. This addition suggests that the Court may have enjoyed the same power to entertain coercive actions against the federal governnent as it enjoyed with respect to state governments under the terms of the existing grant. After the intervening attack on the original jurisdiction of the lower federal courts dissipated, the convention retreated from its earlier provision for original cognizance of U.S.party claims.

Whatever one's interpretation of this sequence of events, ${ }^{287}$ the simple fact that the state-party grant as reported by the Committee of Detail survived the close scrutiny of the delegates demonstrates the convention's commitment to a constitutional structure for the control of the states. Indeed, as we shall see, the ratification debates contain strong evidence that the grant of original jurisdiction was a central element in the convention's plan.

\section{Original Jurisdiction Before the People}

A full understanding of the ratification debates requires appreciation of the Federalists' strategy for securing approval of the Constitution. The Federalists were proposing in their Constitution a new vision of government, and the anti-Federalists were cast in the position of arguing against the proposal. The Federalists tended to focus on the anti-Federalists' criticisms of their plan, rather than offer a fully developed affirmative account of the meaning of its individual provisions. ${ }^{288}$ Even the Federalist Papers themselves, which often outline the structure of the government with startling clarity, were in good measure a response to critiques levelled by others.

involving the United States as a party-an omission that I believe was driven by concerns about sovereign immunity.

287. Professor Charles Warren argued that the framers' decision to omit U.S.-party cases from the Court's original docket was motivated by concerns about the vast number of cases that the United States might prosecute on the Court's original docket through such a grant. See WARREN, supra note 83, at 537. Although the framers may have worried about the manageability of the Court's docket, it is doubtful that such concerns were paramount. Recall that the then-current draft of Article III allowed Congress to assign all original matters (except impeachments) to lower federal courts. See supra note 261. Such assignments could address the problem of an overworked supreme tribunal, if and when it arose. More likely, debate focused on the odds that state courts might deal unfairly with claims brought by or against the United States and on the possibility that a mandatory grant of original jurisdiction vould effect a waiver of the government's sovereign immunity.

288. GoEBEL, supra note 234 , at $28 \mathrm{I}-82$; see also Clinton, supra note 156 , at 803 (contending that "[f]ederalist responses to the antifederalist concerns reflect the political nature of much of the ratification debates). 
As a consequence of the Federalists' strategy, the ratification debates rarely mention the Original Jurisdiction Clause. ${ }^{289}$ Anti-Federalists had not attacked the clause extensively, and it does not appear to have been an issue in the debates in Pennsylvania, North Carolina, or elsewhere. The issue of state suability, broadly understood, did arise in both New York and Virginia. We must therefore examine closely the remarks of Hamilton and Madison, both of whom addressed themselves to the question of state suability in terms that may appear to deny the thesis of this Article. In truth, however, their remarks lend a good deal of support for this Article's claim about the meaning of the Original Jurisdiction Clause.

Hamilton maintained that, by adopting the Constitution, the states would surrender their immunity to the extent necessary to effectuate federal law. At the same time, he denied the anti-Federalist's complaint that the states would also surrender their immunity in non-federal controversies with individual suitors. In a complex argument in The Federalist Nos. 80 and 81 , Hamilton expressed an understanding that the Court's original jurisdiction would serve the enforcement of federal law against the states. Indeed, his discussion of the implications of the clause appears to rest on his understanding of the important difference between the states' law-ofnations and common law immunity.

Hamilton's argument about the suability of states begins in The Federalist No. $80-$ a paper devoted to explaining the jurisdictional menu-with an affirmation that the "plan of the convention" prohibited the states from "doing a variety of things." 290 A constitutional mechanism was needed to ensure state compliance with such prohibitions; the prohibitions would be disregarded "without some constitutional mode of enforcing the observance of them."291 According to Hamilton, policing such infractions was the job of the federal judiciary: the federal courts were granted the authority to "over-rule such as might be in manifest contravention of the articles of union."292 Hamilton thus affirmed that the states were bound by, and subject to suit in all cases that implicated, supreme federal law. ${ }^{293}$

Hamilton regarded states as subject to suit in federal court not only in cases arising under the Constitution but also in actions brought pursuant to at least three other jurisdictional grants. ${ }^{294}$ First, Hamilton held that states

289. See Note, The Original Jurisdiction of the United States Supreme Court, 11 Stan. L. Rev. 665,665 n.3 (1959) (stating that there are few records from the convention that address the Original Jurisdiction Clause).

290. The Federalist No. 80, at 535 (Alexander Hamilton) (Jacob E. Cooke cd., 1961).

291. Id.

292. Id.

293. Note, in particular, the symmetry between his suggestion in The Federalist No. 80 that the "plan of the convention" had prohibited the states from doing a variety of things, $i d$. at 535 , and his later suggestion in The Federalist No. 81 that immunity would remain intact in the absence of its surrender in the "plan of the convention," id. at 549.

294. In addition to the three heads mentioned in the text, Hamilton appears to have regarded states as suable in cases arising under treaties, although the complexity of his argument admits of some 
were subject to suit in actions brought against them by the United States in "controversies to which the United States shall be a party."295 Second, Hamilton believed that states were subject to suit in "controversies" between two or more states. ${ }^{296}$ Finally, Hamilton thought the federal courts would enjoy jurisdiction "in all cases in which one state or its citizens are opposed to another state or its citizens"297 _an acknowledgement that the federal courts could assert jurisdiction over claims brought by individuals against the states. ${ }^{298}$

Having established the manner in which the menu subjected states to suit in federal court, Hamilton turned in The Federalist No. 81 to the Original Jurisdiction Clause. A close reading of Hamilton's discussion confirms the key theses of this Article: that states were subject to original suit despite any law-of-nations immunity they may have enjoyed under the Articles of Confederation and that the extent of any retained common law immunity turned on more complex inquiries into the scope of states' federal law obligations. But one must look closely at the structure of Hamilton's argument to understand how it affirms the surrender of state sovereign immunity.

Hamilton presented the following argument. After introducing the topic of original jurisdiction in state-party cases, ${ }^{299}$ he launched into a digression that denied state suability in one class of disputes that he presumably thought were within the scope of the Court's original jurisdiction,

ambiguity on the point. In The Federalist No. 80, Hamilton seeks to justify federal judicial power, in part, by arguing that the national courts should entertain all actions that implicate national peace and harmony. Id. at 535-36. Hamilton justifies federal enforcement of treaties, for instance, on such grounds. Id. at 540. While he does not expressly declare state suability in such cases, he does affirm that the union must answer to "foreign powers for the conduct of its members." Id. at 536. In other words, Hamilton appears to claim a power to enforce treaties against the states on the theory that the national government bears responsibility for assuring general compliance with them.

295. Id. at 539. Hamilton explained the federal courts' jurisdiction of U.S.-party controversies as encompassing disputes between "the nation and its members or citizens." Id. at 535. For other instances in which Hamilton uses the term "members" to describe the states of the union, see $i d$. at 537.

296. Id. at 539 .

297. Id. at 537 .

298. For others who have read Hamilton's statement here as contemplating suits by individuals against the states, as well as those who have disagreed, see John E. Nowak, The Scope of Congressional Power to Create Causes of Action Against State Governments and the History of the Eleventh and Fourteenth Amendments, 75 Colum. L. REv. 1413, I427-28 (1975). In his Commentaries, Story said he found Hamilton's position here difficult to square with that in The Federalist No. 81's digression. See STORY, supra note 213 , at 548 n.I.

299. Aware of the subject's explosive character, Hamilton devoted only a few well-chosen words to it: "In cases in which a state might happen to be a party, it would ill suit its dignity to be turned over to an inferior tribunal." The FederAlist No. 81, at 548 (Alexander Hamilton) (Jacob E. Cooke ed., 1961).

Some may argue that Hamilton's concern that the states not be consigned to tribunals not befitting their "dignity" reflects his undcrstanding that the lower federal courts were barred from hearing disputes assigned to the Court's original jurisdiction. Such an argument, in my view, is difficult to square with the handling of the Assignment Clause by the convention, see supra note 261, which clearly assumed that Congress could assign the Court's original jurisdiction to lower federal courts. 
because they were cases "in which a State shall be Party."300 These were actions brought by individual creditors to collect the face value of the devalued public securities that states had issued during the Revolutionary War. ${ }^{301}$ Hamilton denied any risk of liability in such actions and did so on the ground that the contracts between individual claimants and the states would confer no right of action independent of the sovereign will.302 Hamilton concluded by noting that the Court's original jurisdiction was limited to "two classes of causes, and those of a nature rarely to occur."303

Although many have read Hamilton's digression as a ringing endorsement of state sovereign immunity, it stops far short of confirming a broad rule of state immunity. The digression discusses only one of the several sources of federal jurisdiction over claims against the states that Hamilton had identified in The Federalist No. 80. It concerns in particular state-

300. The Federalist No. 81, at 548 (Alexander Hamilton) (Jacob E. Cooke cd., 1961). References to Hamilton's digression appear in virtually every major treatment of the doctrine of state sovereign immunity. For treatments of the digression by the Supreme Court, see Hans v. Louisiana, 134 U.S. 1, 12-15 (1890) (holding that a state cannot be sued in a federal question case in a federal court by one of its own citizens); Atascadero State Hosp. v. Scanlon, 473 U.S. 234, 263-64 (1985) (Brennan, J., dissenting) (suggesting that delegates would have been willing to permit suits against states in federal question cases); Welch v. Texas Dep't of Highways \& Pub. Transp., 483 U.S. 468, 480 \& n.10 (1987) (holding that the Jones Act does not abrogate a state's sovereign immunity in a case against the state by one of its citizens). For discussions in the literature, see JACOBS, supra note 84, at 36-37; ORTH, supra note 98, at 25-26; Fletcher, supra note 91, at 1047-48 \& nn.63-64; Gibbons, supra note 84, at 1910-12; Massey, supra note 4, at 94-96; Nowak, supra note 298, at 1429.

301. The assertion that triggered Hamilton's digression had been made by "Brutus" in pamphlets directed at the New York ratifying convention. See Essays of Brutus (No. XIII) (Feb. 21, 1788), supra note 50, at 428-31); see also Letters from the Federal Farmer (No. III) (Oct. 10, 1787), supra note 98, at 245. Thus, Hamilton was responding to the anti-Federalist charge that "an assignment of the public securities of one state to the citizens of another, would enable them to prosecute that state in the federal courts for the amount of those securities." ThE FEDERALIST No. 81, at 548 (Alexander Hamilton) (Jacob E. Cooke ed., 1961). For an account of the importance of the states' Revolutionary War debt in the debate over the suability of states, see $\mathrm{J}_{\mathrm{ACOBS}}$, supra note 84 . at 36-39. On its importance to the ratification of the Eleventh Amendment, see Fletcher, supra note 3, at 1271-75; Marshall, supra note 4, at 1354-55.

302. Hamilton dismissed the anti-Federalists' claim with the following argument:

It is inherent in the nature of sovereignty, not to be amenable to the suit of an individual without its consent. This is the general sense and the general practice of mankind; and the exemption, as one of the attributes of sovereignty, is now enjoyed by the government of every state in the union. Unless therefore, there is a surrender of this immunity in the plan of the convention, it will remain with the states, and the danger intimated must be merely ideal. The circumstances which are necessary to produce an alienation of state sovereignty, wcre discussed in considering the article of taxation, and need not be repeated here. A recurrence to the principles there established will satisfy us, that there is no colour to pretend that the state governments, would by the adoption of that plan, be divested of the privilege of paying their own debts in their own way, free from every constraint but that which flows from the obligations of good faith. The contracts between a nation and individuals are only binding on the conscience of the sovereign, and have no pretensions to a compulsive force. They confer no right of action independent of the sovereign will.

The Federalist No. 81, at 548-49 (Alexander Hamilton) (Jacob E. Cooke ed., 1961).

303. Id. at 549. His use of "rarely" reinforces the impression that he is intentionally downplaying, for propagandistic purposes, the role of the Court in the enforeement of federal law against the states. 
diverse citizen disputes over the payment of existing state debts, ${ }^{304}$ disputes in which no source of supreme federal law binds the states. ${ }^{305}$ The Constitution neither imposes a rule governing state obligations to individuals ${ }^{306}$ nor authorizes Congress to do so. Thus, Hamilton in effect argued only that sovereign immunity barred suits against the state in the absence of consent and that no consent to such suit could be imputed to the mere grant of jurisdiction over controversies between a state and diverse citizens. The digression was intended simply to deny the anti-Federalist's claim that the states' surrender of immunity under the proposed Constitution would extend to non-federal controversies. ${ }^{307}$

In fact, against the backdrop of the earlier discussion in The Federalist No. 80, a close reading of the digression reveals that Hamilton expected the federal judiciary to effectuate federal law by asserting original jurisdiction over claims against the states. The existence of federal judicial power over state-diverse citizen controversies, he admitted, did not carry with it a federal right of action against the state on existing securities. Contracts between the state and the holders of its securities, Hamilton said, "confer no right of action independent of the sovereign will."308 This phrasing implies an important distinction between the existence of federal jurisdiction and the existence of federal power, whether congressional or judicial, to establish a cause of action against the states. ${ }^{309}$ Such federal causes of action, as Hamilton's earlier discussion in The Federalist No. 80 suggests, would arise to enforce constitutional limits on state action. They would not arise,

304. Others have agreed that Hamilton's digression was limited to the state-diverse citizen head of jurisdiction and did not necessarily deny the suability of states in actions brought under other jurisdictional grants. See, e.g., Gibbons, supra note 84, at 1911-12 (reading Hamilton's digression as "arguing not so much that the federal courts would not have jurisdiction over suits [by individuals regarding the payment of state debts] as that there would not be any right of action for plaintiff to sue on"); Fletcher, supra note 91, at 1042-45 (discussing contexts in which a state might be sued by its own citizens).

305. See supra notes 200-05 and accompanying text.

306. The fact that Hamilton's digression responds to the specific claim that individuals would assign securities to diverse citizens for the purpose of manufaeturing diversity jurisdiction indicates that Hamilton did not intend to foreclose the possibility of claims against the states under the Impairments Clause or any other claims that would arise under federal law. The Supreme Court first applied the Impairments Clause to a state's breach of contract in Fletcher v. Peck, 10 U.S. (6 Cranch) 87, 137, 140 (1810). For assessments of the decision, see Amar, supra note 82, at 1470 n.188.

307. Haimiton simply emphasized that the scope of federal jurisdiction over "controversies" bctween a state and diverse citizens did not extend the reach of the Constitution and did not provide an occasion for the surrender of sovereign immunity. Hamilton's digression thus does not foreclose the possibility of distinguishing between states' surrender of immunity in "cases" that implicated federal law and their retention of immunity in "controversies" that tumed on local law.

308. The Federalist No. 81, at 549 (Alexander Hamilton) (Jacob E. Cooke, ed. 1961).

309. It was this distinction that Justice Iredell emphasized in dissenting from the assertion of jurisdiction in Chisholm, see supra note 205 and accompanying text, and this distinction that revisionists have, in part, relied upon in challenging the profound shock theory of the Eleventh Amendment. See Amar, supra note 82, at 1473-75; Fletcher, supra note 91, at 1045-46; Gibbons, supra note 84, at 191112; see also Atascadero State Hosp. v. Scanlon, 473 U.S. 234, 263-64 (1985) (Brennan, J., dissenting). 
Hamilton explains in The Federalist No. 81, in connection with non-federal disputes over the states' public debt.

Hamilton's remarks suggest a distinction, much like that proposed in this Article, between the states' law-of-nations immunity (which the Original Jurisdiction Clause had overcome) and their common law immunity, which remained intact except where federal law created enforceable obligations on the states. ${ }^{310}$ Note that, early in the digression, Hamilton anchored state immunity in "the general sense and the general practice of mankind"- an apparent reference to immunity under the law of nations. ${ }^{311}$ Yet Hamilton did not contend that such an immunity would survive the adoption of Article III; he admitted in fact that the Constitution can produce what he termed an "alienation of state sovereignty," 312 and he clearly believed that the Original Jurisdiction Clause confers jurisdiction on the federal courts to entertain actions against the states. His focus, instead, was on the states' common law immunity, emphasizing the absence of any common law right to pursue such claims against the states, the absence of any federal authority over such contracts, and the absurdity of recognizing a judicially implied right of action "by mere implication." 313

The entire tenor of the discussion suggests, then, that Hamilton believed that the Court's original jurisdiction over state-party "cases" was designed to guarantee state comphance with federal law. His consideration of the Court's original jurisdiction over state-party cases-the central topic of The Federalist No. 81-served as a natural springboard into his argument that any surrender of common law immunity did not extend beyond disputes that implicated suprene federal law. ${ }^{314} \mathrm{He}$ simply sought to downplay the true effect on state sovereignty of the original jurisdiction's state-party provision by emphasizing in a digression certain limits on the scope of the surrender of state sovereign immunity. ${ }^{315}$

Although Hamilton had not spelled out the scope of the states' surrender of sovereign immunity in detail, his implicit message was not lost on the members of the New York ratifying convention. New York proposed a

310. It is also significant that Hamilton ascribed the existence of the Court's original docket to the dignitary interests of the states and not, as the Court has suggested, to a desire to enable the states to sue others in a convenient, centralized forum. See supra note 47 and accompanying text (citing Justice Harlan's convenient forum theory of the Original Jurisdiction Clause). This suggests that Hamilton viewed the clause as providing a forum for suits against the states as well as suits by the states, bccause such suits implicate the states' dignitary interest far more directly than suits brought by the states.

311. The Federalist No. 81, at 549 (Alexander Hamilton) (Jacob E. Cooke cd., 1961).

312. Id.

313. Id.

314. Hamilton's use of contract imagery, in the course of affirming the states' retained immunity, was also highly suggestive. His description of "contracts between a nation and individuals" as binding only "on the conscience" of the states strongly implies an understanding of constitutional obligations, by contrast, as binding on the states as a matter of law. See id.

315. Had Hamilton not regarded the provision as effecting a surrender of state sovereign immunity, his discussion of retained immunity in state-party "controversies" would have been more than a mcre digression of the "immediate subject" of his paper: it would have been entirely irrelevant. 
resolution calling for a constitutional amendment that would bar the federal courts from entertaining any kind of suit against a state "in any manner whatever." 316 The introduction of such an amendment suggests that the delegates understood the implication of The Federalist No. 80 and The Federalist No. 81, and that at least some of them were unwilling to accept the surrender of state sovereign immunity entailed by the extension of the Court's original jurisdiction to state-party cases.

As in New York, the proceedings of the Virginia ratification convention offer strong support for this Article's thesis. Some months before the Virginia convention met, ${ }^{317}$ Madison had argued as Publius that the Supreme Court would exercise original jurisdiction over claims against state defendants. ${ }^{318}$ Madison cited the Court's original jurisdiction in The Federalist No. 39 to illustrate his claim that the government would operate both in a national fashion on the individual citizens of the union and in a federal fashion "on the [states] conposing the confederacy, in their political capacities." ${ }^{319}$ As Madison explained:

On trying the Constitution by this criterion [of operation], it falls under the national, not the federal character; though perhaps not so compleatly, as has been understood. In several cases and particularly in the trial of controversies to which States may be parties, they must be viewed and proceeded against in their collective and political capacities only. So far the national countenance of the Government on this side seems to be disfigured by a few federal features. But this blemish is perhaps unavoidable in any plan; and the operation of the Government on the people in their individual capacities, in its ordinary and most essential proceedings, may on the whole designate it in this relation a national Government. ${ }^{320}$

316. See 2 Elliot's Debates, supra note 50, at 409 (suggesting that "nothing in the Constitution now under consideration ... . is to be construed to authorize any suit to be brought against any state, in any manner whatever").

317. Madison's argument in The Federalist No. 39 appeared on January 16, 1788; the Virginia convention opened on June 2, 1788. See 2 The Debate on the Constrtution 26, 1067 (Bernard Bailyn ed., 1993).

318. Madison's view of the Original Jurisdiction Clause appears in The Federalist No. 39's response to the anti-Federalist argument that the Constitution would establish a national government, which "regards the union as a consolidation of the States." THE FEDERALIST No. 39, at 253 (James Madison) (Jacob E. Cooke ed., 1961). Madison met this claim head on, arguing that the plan of the convention had produced a Constitution that was "in strictness neither a national nor a federal constitution; but a composition of both." Id. at 257. In the course of his discussion, Madison invoked the original jurisdiction of the Supreme Court in state-party cases as an illustration of the plan's federal operation.

319. Id. at 255 .

320. Id. at $255-56$. 
Madison thus points to the Original Jurisdiction Clause, which he paraphrases, in arguing that the Constitution contemplates coercive actions against the states in their "collective and political capacities." 321

Understood against the background of this direct affirmation of the link between the Original Jurisdiction Clause and the suability of states, Madison's debating posture at the Virginia convention appears closely to resemble that of Hamilton in New York. Madison began his remarks in the Virginia debates by affirming that cases arising under the Constitution would embrace "causes of a federal nature" brought against the states to enforce constitutional prohibitions. ${ }^{322}$ His earlier argument in The Federalist No. 39 demonstrates that he may well have regarded the Court's original jurisdiction as the vehicle for enforcing such restrictions. ${ }^{323}$ Indeed, both discussions express the same tone of regret at the necessity of conferring such jurisdiction. Note how closely The Federalist No. 39's description of coercive actions against the states (a "blemish [that] is perhaps unavoidable under any plan"324) resembles Madison's description in the Virginia convention ("a misfortune ... . in organizing any government"). ${ }^{325}$

Like Hamilton, Madison sought to downplay the significance of the states' suability. Later in the Virginia debates, Madison denied that federal courts were to hear suits brought by individuals against the states. ${ }^{326}$ Many modern observers have read Madison's comment as a broad affirmation of state sovereigu immunity. Yet Madison's comment, like that in Hamilton's digression, came in the course of a discussion of federal jurisdiction over non-federal controversies between the states and diverse citizens. ${ }^{327}$ Nowhere in that comment does Madison deny that states were subject to suit in actions that arose under federal law. Indeed, his introductory remarks to the Virginia delegates and his earlier analysis in The Federalist No. 39 specifically affirm the necessity of such suits.

If Madison's account of the Court's original jurisdiction in the Virginia debates was less candid than his account in The Federalist No. 39, others were far more forthcoming. Edmund Pendleton, a delegate to the

321. Id. at 255. It seems evident that Madison had the original jurisdiction of the Supreme Court in mind. His comment adverts to judicial process ("the trial of controversies"), and paraphrases the Original Jurisdiction Clause in terms ("to which States may be parties") that cannot be confused with any other provision of Article III. See id. No one would argue that Madison's comment failed to identify the possibility of suits against the states; indeed, he had such suits directly in mind. Finally, Madison's reference to state-party "controversies" does not necessarily imply that he had adoptcd a party alignment reading of the Original Jurisdiction Clause. To the contrary, Madison appears to suggest that the Court's jurisdiction over claims against the states would embrace "several cases" and, in particular, the trial of controversies.

322. 3 Ellor's DeBatEs, supra note 50 , at 532 (remarks of Jaines Madison).

323. See supra text accompanying notes 320-21.

324. The Federalist No. 39, at 255 (Janes Madison) (Jacob E. Cooke ed., 1961).

325. 3 Ellior's Debates, supra note 50, at 532 (remarks of James Madison).

326. Id. at 533 .

327. Id. at 526-27 (remarks of George Mason). 
Philadelphia convention and the first Federalist to address the Virginia convention on the nieaning of Article III, offered the following account: "The inupossibility of calling a sovereign state before the jurisdiction of another sovereign state, shows the propriety and necessity of vesting this tribunal with the decision of controversies to which a state shall be a party." 328 Pendleton's remark reflects his understanding that suits against the states were cognizable on the Court's original docket. ${ }^{329}$ It also shows that the framers understood the law of nations to deprive the state courts of the power to hear such claims. Pendleton's comment thus offers strong support for this Article's thesis that it was the perceived inadequacy of the state courts, and not a distrust of lower federal courts, that led to the adoption of the Original Jurisdiction Clause. ${ }^{330}$

Additional support for this thesis appears in the renuarks of Edmund Randolph and Patrick Henry. Patrick Henry pointed out that Article III spoke of states as parties to controversies and not solely as plaintiffs. ${ }^{331}$ In a comment on an earlier exchange over the power of federal courts to entertain actions against the states, Randolph squarely affirmed that they could do so: "I think, whatever the law of nations may say, that any doubt respecting the construction that a state may be plaintiff, and not defendant, is taken away by the words where a state shall be a party." 332 Hence, Randolph pointed to the text of the Original Jurisdiction Clause as the source of federal jurisdiction over claims against the states and indicated

328. Id. at 549 (remarks of Edmund Pendleton).

329. Some might contend that Pendleton's use of "controversies" here refers only to the diverseparty matters that Article III describes as such and so excludes federal question "cases" from the Court's original docket. But Pendleton may well have used the term "controversies" here not as a term of art to describe specific matters on the jurisdictional menu of Article III, but rather as a description of the civil nature of the state-party matters he expected the Court to entertain.

In the course of introducing the subjects to which the jurisdictional menu extends the judicial power, Pendleton had carefully distinguished between "cases" and "controversies." See id. at 517-18. When he tumed, one paragraph later, to the Original Jurisdiction Clause, he had this to say: "The next clause settles the original jurisdiction of the Supreme Court, confining it to two eases-that of ambassadors, ministers, and consuls, and those in which a state shall be a party. It excludes its original jurisdiction in all other cases." Id. at 518. As this comment reflects, Pendleton read the original clause as applying to state-party "cases," not state-party "controversies." Such a reading, coupled with Pendleton's evident grasp of the menu's distinction between cases and controversies, tends to imply a federal question interpretation of the clause. Pendleton's later reference to controversies involving the states makes less sense as a repudiation of his earlier interpretation than as a general description of civil matters.

330. Pendleton had earlier made clear his understanding that the grant of original jurisdiction did not bar Congress from conferring concurrent jurisdiction on the lower federal courts in such matters. See id. at 518 ("But it appears to me that [the grant of original jurisdiction] will not restrain Congress froin regulating even these, so as to permit foreign ambassadors to sue in the inferior courts, or even to compel them to do so, where their causes may be trivial ....").

331. See id. at 543 (remarks of Patrick Henry) ("But he says that the state may be plaintiff only. If gentlemen pervert the most clear expressions, and the usual meaning of the language of the people, there is an end of all argument. What says the paper? That it shall have cognizance of controversies between a state and citizens of another state without discriminating between plaintiff and defendant.").

332. Id. at 573 (remarks of Edmund Randolph). 
that the clause sought to overcome barriers to state suability posed by state immumity under the law of nations.

The participants in the Virginia debate appear to have generally accepted the Pendleton-Randolph account of the Original Jurisdiction Clause. No one rose to take issue with the linkage Pendleton and Randolph drew between the clause and the framers' desire to overcome the states' immunity under the law of nations; no one offered a competing account of the purpose of the Original Jurisdiction Clause; indeed, no one aside from Pendleton, Henry, and Randolph mentioned the clause at all. All three participants described the clause as authorizing suits against the states and, in light of their political differences, this agreement must have been decisive for the delegates on the question of state suability.

The Virginia delegates appear to have accepted the Original Jurisdiction Clause, not only as explained by Pendleton and Randolph, but also as a necessary element of the constitutional plan. In proposed amendments to the Constitution, the Virginia convention would have altered Article III to vest the judicial power in one Supreme Court and such inferior courts of admiralty as Congress might choose to create. ${ }^{333}$ Such a proposal would have precluded Congress from creating lower federal courts with general federal question or diversity jurisdiction and would have directly presented the prospect that state courts would act as courts of first instance for much federal business. Yet the amendment proposed to retain the grant of original jurisdiction in state-party cases, in keeping with this Article's suggestion that the grant was necessary to overcome the states' law-ofnations immunity from suit in state end federal court.

\section{The Report of Edmund Randolph}

A 1790 report by Edmund Randolph, the author of an early draft of Article III and the country's first Attorney General, also provides evidence of the connection between original jurisdiction and state suability. Randolph, an able lawyer who served as Virginia's Attorney General during the Articles of Confederation period, ${ }^{334}$ was an extremely knowledgeable participant in the framing of the Constitution. As a member of the Commit-

333. The Virginia amendment provided a substitute for Article III:

That the judicial power of the United States shall be vested in one Supreme Court, and in such courts of admiralty as Congress may from time to time ordain and establish in any of the different states. ... In all cases affecting ambassadors, other foreign ministers, and consuls, and those in which a state shall be a party, the Supreme Court shall have original jurisdiction.

3 Elliot's DeBATES, supra note 50, at 660.

334. For a portrait of Randolph before the framing of the Constitution, see WILLs, supra note 132, at 10-11. As attorney general, Randolph represented the Commonwealth in the arbitration of Simon Nathan's claim at Annapolis, Maryland. See supra note 126. Randolph refers to the Nathan case in his comments during the ratification debates. See 3 ELtior's DEBATEs, supra note 50, at 571 (remarks of Edmund Randolph) (arguing that federal courts are essential to provide an impartial forum for disputes between states and diverse citizens and noting that the legislature of Virginia "[i]n the case of Mr. Nathan ... thought the determination of the dispute ought to be out of the state, for fear of partiality"). 
tee of Detail in Philadelphia, he had drafted the version of Article III to which Wilson reacted in establishing the Court's original jurisdiction in state-party cases. ${ }^{335}$ Unlike Oliver Ellsworth, his colleague on the Committee of Detail and the principal draftsman of the Judiciary Act of 1789, Randolph had also attended the convention debates over the Committee draft of Article III. ${ }^{336}$ Randolph was thus in a position to understand both the function of the Original Jurisdiction Clause and the scope of federal jurisdiction over "cases" arising under the Constitution-a jurisdictional grant that the convention added to Article III after Ellsworth left.

As we have already seen, Randolph took the position in the Virgima ratification debates that the Court's grant of original jurisdiction plainly authorized suits against the states. He later expanded on that position as counsel to the plaintiff in Chisholm v. Georgia. ${ }^{337}$ But perhaps the clearest and most comprehensive articulation of Randolph's understanding appears in a report he submitted to Congress one year after the passage of the Judiciary Act of $1789 .{ }^{338}$ Randolph's 1790 report offers a detailed criticism of the Judiciary Act and a proposed substitute statute, together with notes that explain the meaning of his proposal's various provisions. The report leaves no doubt that Randolph understood the Origimal Jurisdiction Clause to trump the states' sovereign immunity under the law of nations and under the common law in all federal question "cases."

Randolph begins his discussion of state sovereign immunity by providing a general account of the immunity problem consistent with that developed in this Article:

[A]s far as a particular state can be a party defendant, a sister state cannot be her judge. Were the states of America unconfederated, they would be as free from mutual controul as other disjoined nations. Nor does the federal compact narrow this exemption; but confirms it, by establishing a common arbiter in the federal judiciary, whose constitutional authority may administer redress.

It deserves however to be remarked in this place, that these ideas are not inconsistent with the right of the states separately ... to resort to the state courts as plaintiffs; nor yet with the right of the states separately to open their own courts for suits against themselves. ${ }^{339}$

335. See supra notes 253-59 and accompanying text.

336. On Ellsworth's early departure from the convention, and his absence from the crucial debate on the Judiciary Article, see Clinton, supra note 150 , at 1524, 1526-27.

337. 2 U.S. ( 2 Dall.) 419, 420-21 (1793) (counsel's argument) (relying on textual analysis, as well as policy and original-intent arguments).

338. See 4 Documentary History of the Supreme Court, supra note 41, at 122-67 (reprinting Randolph's report). For background on Randolph's report, see Wythe Holt, "Federal Courts as the Asylum to Federal Interests": Randolph's Report, The Benson Amendment, and the "Original Understanding" of the Federal Judiciary, 36 BuFF. L. Rev. 341 (1987) (footnote omitted); Clinton, supra note 150, at 1552-56.

339. See 4 Documentary History of the Supreme Court, supra note-41, at 130. 
Randolph thus recognized the distinction between the states' law-of-nations sovereign immunity (which barred state courts from hearing claims against sister-state defendants) and the states' immunity in their own courts (which flows from the common law, and remains subject to waiver by the state's legislature). Randolph also noted that states were free, both before and after the framing of the Constitution, to litigate as plaintiffs in other states' courts-an understanding that confirms my claim that a distinctive feature of the State-party Clause was its provision for the appearance of states as defendants.

Randolph not only understood the problem of state sovereign immunity in terms similar to those offered here but also viewed Article III as directly addressing the question of suability. Randolph's proposed judiciary code deliberately extended the statutory grant of the Court's original jurisdiction to all ambassador cases and to "those [in] which a state shall be a party." ${ }^{340}$ Such a choice of language quite consciously followed Article III word for word; Randolph had earlier criticized the Judiciary Act's handling of federal jurisdiction for departing from the terms of the Constitution. ${ }^{341}$ Randolph meant to adhere literally to the Original Jurisdiction Clause, and his draft statute would have authorized the Court to hear claims against the states as defendants. Indeed, he explained that his statute would make the states "suable . . . in the supreme court."342

In making the states suable in the Supreme Court, Randolph's bill clearly contemplated their suability in federal question cases. Randolph's draft bill conferred jurisdiction on federal district and circuit courts to hear all cases arising under the Constitution, laws, and treaties of the United States. ${ }^{343}$ Randolph understood that, standing alone, such broad grants of subject matter jurisdiction would extend to federal question claims brought against the states as parties. His draft thus included two provisos that expressly prohibited the lower federal courts from hearing such claims against the states. ${ }^{344}$ By denying the lower federal courts authority over such claims, and by consolidating all such jurisdiction in the Supreme Court, Randolph made clear that the Court's original jurisdiction over stateparty "cases" encompassed federal question claims against the states.

340. Id. at 152 .

341. See Letter from Edmund Randolph to James Madison (June 30, 1789), in id. at 432 ("The jurisdiction is inartificially, untechnically and confusedly worded. Would it not have been sufficient to have left this point upon the constitution itself? Will the courts be bound by any definition of authority, which the constitution does not in their opinion warrant?').

342. See id. at 165 n.20.

343. Id. at $140-41,148$.

344. Randolph's statute provides, "The jurisdiction herein before given to the district courts over cases arising under the Constitution, the laws and treaties of the United States, shall not be construed to comprehend such cases in which the United States, or a particular State, sball be defendant." Id. at 142; see also id. at 149 (proposing that the jurisdiction of the circuit courts over federal question cases "shall not be construed to comprehend such cases in which a particular state shall be defendant"). 
Not content merely to embed his federal question reading of the Original Jurisdiction Clause in the structure of his draft statute, Randolph appended to the statute notes that confirm his understanding that federal jurisdiction extended to claims brought against the states to enforce federal law. In commenting on the provisos barring lower federal courts from hearing federal question claims against the states, Randolph had this to say:

This restriction assumes for its foundation, that cases arising under the constitution, laws and treaties of the United States, between any persons or bodies whatsoever, not specially protected by the law of nations, are not without the reach of the judiciary power of the United States. For the subsequent descriptions of persons and bodies, spread, instead of contracting the jurisdiction. ${ }^{345}$

Randolph's explanation of the relationship between jurisdiction over "cases" and "controversies" is virtually identical to that later offered by Justice Harlan in United States v. Texas. ${ }^{346}$ This distinction underlay Randolph's view that states were suable as defendants in federal question cases. $^{347}$

Understanding that a regime that subjected states to federal jurisdiction would prove controversial, Randolph proceeded to explain his conclusion that states were suable as defendants in federal court:

[C]an the United States, or a particular state, be defendant? To be a party, as is the phrase of the Constitution, is to be a plaintiff or defendant. Do the rights of sovereignty forbid the latter? They do not, where the sovereign becomes defendant with his own consent. The Constitution is such an act of consent, done by the United States and the individual states; unless it be interpreted, that the individual States may be a party now, only as they were before, to wit, as sovereigns, and that the United States should be on the same footing. To this may be opposed the facihty with which the Constitution might have suppressed any ambiguity, by using the word "plaintiff," instead of "party":- the propriety of informing public bodies, that

345. Id. at 163 n.9.

346. See supra notes 70-76 and accompanying text.

347. To be sure, Randolph draws the distinction between "cases" and "controversies" in the quoted statement without mentioning "controversies" by name. But his reference in the last sentence of the quote to "subsequent descriptions of persons and bodies" can only refer to the "controversy" heads of jurisdiction, which define judicial power by party alignment. In context, Randolph says the same thing that Marshall and Harlan later said: that states may be parties in both the federal question and admiralty "cases" as well as in the party-alignment "controversies."

It is also worth noting that Randolph's reference to bodies shielded by the law of nations did not encompass the states but rather referred to foreign countries. Although his draft statute conferred jurisdiction on the circuit courts to hear claims brought by states against foreign states, see 4 DOCUMENTARY HistoRy OF THE SUPREME COURT, supra note 41, at 148, he apparently did not regard the grant of jurisdiction as vitiating the foreign state's immunity. In describing the Constitution as an act of consent sufficient to effect a waiver of immunity, see infra notes 348 and accompanying text, Randolph includes the United States and the states as consenting parties but does not include foreign states. 
though they are political agents, they are not absolved from moral obligation; and the license which is sometimes given by a sovereign, to scrutimize his pretensions before his own courts. ${ }^{348}$

Randolph's argument thus proceeds along lines similar to those developed here: states had been sovereign under the Articles, but their immunity was subject to waiver through provisions of the Constitution; the framers effected such a waiver by extending the judicial power to all cases and by authorizing the Court to hear claims in which the states appeared as either defendants or plaintiffs; the framers' decision to effect such a waiver of immunity was motivated by their desire to ensure lawful conduct by the political agents of the people and recogmized that many states had effected similar waivers of immunity in their own courts.

\section{E. The Judiciary Act of 1789 and Cohens v. Virginia}

Against the backdrop of this review of the text, history, and structure of Article III, one may wonder why the diverse-party reading has become so ingrained in our understanding of the Court's original jurisdiction. In this Section, I suggest that the answer lies in the party focus of section 13 of the Judiciary Act of $1789^{349}$ and in Marshall's opinion in Cohens $v$. Virginia. ${ }^{350}$ Neither source, however, offers any substantial argumentapart from settled practice-against the adoption of the federal question approach developed here.

On its face, section 13 of the Judiciary Act of 1789 appears to adopt a diverse-party interpretation of the Court's original jurisdiction. It provides

[t]hat the Supreme Court shall have exclusive jurisdiction of all controversies of a civil nature, where a state is a party, except between a state and its citizens; and except also between a state and citizens of other states, or aliens, in which latter case it shall have original but not exclusive jurisdiction. ${ }^{351}$

Although the Act confers jurisdiction on the Court in all "controversies," and might thus be read to encompass all civil matters involving state parties that come within the scope of Article III (including both "cases" and "controversies"), it seems more likely that the drafters had diverse-party controversies in mind. ${ }^{352}$ The failure of the Act's drafters to enpower the Court

348. 4 DOCUMENTARy History of THE SUPREME CourT, supra note 41 , at 163. Wilson made a similar argument in Chisholm. See supra note 93.

349. Ch. 20, 1 Stat. 73, 80-81. For accounts of the history of the Judiciary Act, see Goebel, supra note 234, at 457-508 (narrative of the Act's passage through Congress); Charles Warren, New Light on the History of the Federal Judiciary Act of 1789, 37 HARv. L. Rev. 49 (1923) (legislative history based on textual comparisons of various versions of the bill).

350. 19 U.S. (6 Wheat.) 264 (1821).

351. Ch. 20,1 Stat. 73,80 .

352. Thus, for example, the statute uses the term "controversies" to describe the scope of the Court's original jurisdiction-a choice that may well reflect the drafters' decision to incorporate by reference the controversies that had been described as such in Article III. Moreover, the exception for 
to hear federal question cases against the states, then, appears to argue against the reading I propose here. ${ }^{353}$ Close examination of the Judiciary Act, however, reveals that its enbrace of a diverse-party reading of the Original Jurisdiction Clause was not based on a well-grounded interpretation of that clause.

The leading draftsinan of the Act, Oliver Ellsworth, served on the Committee of Detail but left the convention before it considered the judiciary article on August $27 .^{354} \mathrm{He}$ did not participate in the important changes that were made to the judicial article on that day, and might not have understood its federal focus as well as others, such as Edmund Randolph, who believed that the Original Jurisdiction Clause embraced federal question claims and criticized the Judiciary Act for its omission of such claims from the Court's original docket. ${ }^{355}$ It is noteworthy that this omission was complemented by the Act's omission of federal questions (without regard to party) from the inferior federal tribunals' original jurisdiction. ${ }^{356}$ It remains

disputes between a state and its own citizens (no jurisdiction) and for those between a state and diverse citizens and aliens (concurrent jurisdiction) appears to confirm that the drafters had diverse parties in mind.

Note, however, that a reading of the term "controversies" to incorporate the diverse-party disputes in Article III renders the exception for disputes between a states and its own citizens redundant. Article III did not confer jurisdiction over disputes between a state and its own citizens (except in federal question cases) and the drafters of the Judiciary Act would have had no reason to carve them out in a separate proviso unless they viewed the statutory reference to "controversies" as encompassing such federal question cases. While the argument from redundancy offers some support for a federal question reading of "all controversies," it seems more probable than not that the drafters simply included the first proviso out of an excess of caution and the drafters excluded federal questions from the Court's docket.

In arguing here that section 13's omission of federal question claims involving state parties either represented an ineffeetive or unconstitutional attempt to narrow the Court's original docket, I enter the company of the many observers who have attacked the provision. In addition to Marshall's famous critique in Marbury v. Madison, 5 U.S. (1 Cranch) 137, 173-76 (1803) (concluding that section 13 unconstitutionally conferred original jurisdiction on the Supreme Court to issue writs of mandamus to officers of the federal government), see, for example, Amar, supra note 12, at $264 \mathrm{n} .194$ (contending that the Act was arguably unconstitutional in failing to give the Court jurisdiction in all cases where ambassadors might be "affected"); Amar, supra note 220, at 1533 \& n.113 (citing Ellsworth's contemporaries' criticisms of the Act's clumsy language).

353. Opinions of the Supreme Court have occasionally treated the Judiciary Act of 1789 as a revealing first attempt to implement Article III, emphasizing that many of the framers of the Constitution served in the First Congress that enacted it. See, e.g., Wisconsin v. Pelican Ins. Co., 127 U.S. 265, 297 (1888) (suggesting that the Act, "passed by the first Congress assembled under the Constitution, many of whose members had taken part in framing that instrument, . . . is contemporaneous and weighty evidence of its true meaning"). Close students of the Act have long challenged this "immaculate conception" view of the Judieiary Act, however. See 1 WARREN, supra note 51, at 12 (1922); Felix Frankfurter \& James M. Landis, The Business of the Supreme Court 4 (1927). For a recent account challenging the "immaculate conception" view of the Act, see Clinton, supra note 150, at 1522-27; Holt, "To Establish Justice," supra note 51, at 1518-21. On Randolph's dissatisfaction with the Act, see supra note 34I. For an account of Madison's view of the Act as defective implementation of Artiele III, see GOEBEL, supra note 234, at 507-08.

354. See supra note 336.

355. See supra note 341 and accompanying text.

356. Although the Judiciary Act vested the federal district courts with jurisdiction over revenue matters, seizures on land and water, and federal crimes, it failed to confer upon the lower courts any general grant of jurisdiction over cases arising under the Constitution, laws, and treaties of the United 
unclear whether such omissions stemmed from the drafters' failure to perceive that actions might arise originally under the Constitution, laws, and treaties of the United States, or from a political compromise between Federalist supporters of broad judicial power and anti-Federalist opponents of the federal courts. ${ }^{357}$ Either explanation robs the text of the Judiciary Act of much of its value as an exposition of the framers' intent concerning the Original Jurisdiction Clause.

Like the Judiciary Act on which it was based, Justice Marshall's opinion in Cohens $v$. Virginia ${ }^{358}$ offers little in the way of textual or structural support for the diverse party reading of the Original Jurisdiction Clause that it announces in dicta. In Cohens, ${ }^{359}$ the Commonwealth of Virginia advanced three arguments against the Supreme Court's power to review one of its criminal proceedings, only one of which concerns us here. ${ }^{360}$ Building upon dicta in Marbury v. Madison, ${ }^{361}$ the Commonwealth argued that because the case involved a state party, it was to be heard by the Supreme Court, if at all, as a matter of original jurisdiction. ${ }^{362}$

States. See Clinton, supra note 150, at 1541. As Clinton notes, however, section 25 of the Act gave the Supreme Court the power to review many federal question cases on appeal from the state courts. Id. at 1541-43; see also Amar, supra note 220, at 1529-33 (arguing that section 25's provision for appellate jurisdiction over state courts only where federal claim was denied below derives from a plausible reading of Article III's requirement that a "case" must "arise under" federal law).

357. Professor Warren has suggested that an early draft of the Judiciary Act may have vested the lower federal courts with cognizance of "all cases" of federal judicial jurisdiction over five hundrcd dollars. See 1 WARREN, supra note 51, at 61-62 \& n.29. Professor Clinton speculates that a political compromise between supporters and opponents of the institution of lower federal courts may have led to the omission of such federal question jurisdiction. See Clinton, supra note 150, at 1528 n.38. For a fuller account of the compromises entailed in the passage of the Judiciary Act, see Holt, "To Establish Justice," supra note 51 , at 1485-90.

358. 19 U.S. (6 Wheat.) 264 (1821).

359. Facing a prosecution by the Commonwealth for selling lottery tickets, the Cohens defended on the ground that the sales had been authorized by a Congressional statute regulating lotteries within the District of Columbia. After the state trial court rejected the defendants' claim of federal immunity, the Cohens brought the case to the Supreme Court. See id. at 375-76.

360. Virginia moved to dismiss the writ of error, arguing first that the claim lay beyond fcderal judicial power. Marshall responded to the State's claim by building on the analysis in Justice Story's analysis in Martin v. Hunter's Lessee, 14 U.S. (1 Wheat.) 304, 334 (1816). Marshall highlighted Article III's sweeping provision for jurisdiction over all "cases" arising under the Constitution, laws, and treaties of the United States. Cohens, 19 U.S. at 378-79. In such cases, federal courts enjoy jurisdiction by virtue of the subject in dispute, whoever may be the parties.

Virginia next argued that the Eleventh Amendment barred the Court from hearing claims against the State. Marshall offered a two-part answer to Virginia's Eleventh Amendment claim. First, because the Cohens had appeared as defendants in the original cause, he concluded that the action was not a "suit or proceeding" brought by individuals against the State. Id. at 406-12. Second, he noted that the defendants were citizens of Virginia and thus not within the literal terms of the Eleventh Amendment. See Cohens, 19 U.S. at 412. See generally Jackson, supra note 91, at 23-32 (describing Marshall's limited rationale for rejecting application of the Eleventh Amendment and noting its subsequent evolution into a broad doctrine permitting the assertion of appellate jurisdiction over claims against the states).

361. 5 U.S. (1 Cranch) 137 (1803).

362. Cohens, 19 U.S. (6 Wheat.) at 300-01. The argument of Virginia's counsel was predicated on Marshall's assertion in Marbury, 5 U.S. (1 Cranch) at 174 , that Congress had no power to trifle with 
Marshall offered three cogent arguments against Virginia's gloss on Marbury. In the most important of the three, ${ }^{363}$ Marshall attempted to soften the dicta in Marbury by demonstrating that claims assigned to the Court's original docket inight well appear properly on its appellate docket. $^{364}$ As Marshall concluded, "the power to take cognisance of the suit originally, does not necessarily negative the power to decide upon it on an appeal, if it may originate in a different court." 365 Marshall thus disposed of Virginia's contention that the assertion of appellate jurisdiction over a state-party case was incompatible with the allocation of jurisdiction in Article III.

Marshall nonetheless chose to define the parameters of the Court's original and appellate jurisdiction. After noting that Article III distinguishes between "controversies" (" $t]$ he character of the parties is everything") and "cases" ("the nature of the case is everything"), Marshall offered the following explanation of the Distribution Clause:

When, then, the constitution declares the jurisdiction, in cases where a state shall be a party, to be original, and in all cases arising under the constitution or a law, to be appellate, the conclusion seems irresistible, that its framers designed to include in the first class, those cases in which jurisdiction is given, because a state is a party; and to include in the second, those in which jurisdiction is given, because the case arises under the constitution or a law. ${ }^{366}$

Here, Marshall expresses the view that the Court's original jurisdiction encompasses only party-based controversies and its appellate jurisdiction encompasses all federal question claims to which a state may happen to be a party.

Article III's allocation of the Supreme Court's original and appellate jurisdiction. Marbury seemed to suggest that matters assigned to the Court's original jurisdiction were not to be heard by it on appeal-a principle that, according to Virginia, deprived the Court of appellate jurisdiction in the case before it. See Cohens, 19 U.S. (6 Wheat.) at 300-01.

363. Marshall met the claim in part by noting that the judicial power under Article III did not extend to disputes between a state and its own citizens and thus did not attach as an origimal matter to the state's criminal prosecution of the Cohens in the absence of a federal question. See Cohens, 19 U.S. (6 Wheat.) at 398-99. Marshall bolstered this argument by observing the federal courts' inability to entertain original actions predicated on the penal or criminal statutes of the states. Id. Together, the two arguments (both of which had been advanced by counsel for the Cohens) were sufficient to demonstrate that the exercise of appellate jurisdiction over the federal defense was in no way incompatible with Marbury's view of original and appellate jurisdiction as mutually exclusive.

364. To do so, Marshall hypothesized a circuit court decision in a dispute between a state and a citizen of another state. Id. at 396. Surely the Court enjoyed the power to correct such an erroneous assertion of jurisdiction, despite the fact that such claims had been assigned to the Court's original docket. Id. Marshall made the same demonstration as to foreign consuls, who were authorized to sue in inferior admiralty courts, and whose claims were subject to appellate review in the Supreme Court despite the grant of original jurisdiction over cases affeeting consuls in Article III. Id. at 396-97.

365. Cohens, 19 U.S. ( 6 Wheat.) at 398.

366. Id. at 393-94. 
This is vintage Marshall. ${ }^{367} \mathrm{He}$ distinguishes between "cases" and "controversies" but does not explain as a textual matter why the reference in the Original Jurisdiction Clause to state-party "cases" should be read to encompass matters that the menu describes as "controversies." In his subsequent opinion in Governor of Georgia v. Madrazo, ${ }^{368}$ moreover, Marshall casually rejects the implications of his Cohens dicta in holding that admiralty claims against the states were proper subjects for original Supreme Court cognizance and thus lay beyond the original jurisdiction of the inferior federal admiralty courts. ${ }^{369}$ If we take this reading of Madrazo seriously, it casts doubt on the depth of Marshall's own commitment to a diverse-party reading of the Original Jurisdiction Clause. ${ }^{370}$

Marshall did offer structural arguments in support of his diverse-party reading in Cohens that deserve careful consideration. Marshall offered the uncontroversial proposition that the Court's original docket was constructively limited to claims of a type whose amenability to federal jurisdiction was evident at the time the action was instituted. ${ }^{371}$ Because the identities of both parties would appear on the face of the complaint, disclosing the existence of federal jurisdiction, Marshall believed that diverse-party

367. See Currie, supra note 52, at 661 ("[W]e find in Marbury a number of traits that were to characterize many later Marshall opinions: great rhetorical power, invocation of the constitutional text less as the basis of decision than as a peg on which to hang a result evidently reached on other grounds, a marked disdain for reliance on precedent, . . . a tendency to resolve difficult questions by aggressive assertion of one side of the case, and an absolute certainty in the correctncss of his conclusions.").

368. 26 U.S. (1 Pet.) 110 (1828).

369. See id. at 124. Commentators have been especially unkind to Marshall's Madrazo opinion, characterizing his argument that the Court's original cognizance extended to admiralty claims as a "sophistr[y]." See Gibbons, supra note 84, at 1967 n.427. Gibbons argues that Marshall's reading runs afoul of both Article III, Section 2, which refrains from conferring original jurisdiction on the Court in admiralty cases, and of the Judiciary Act, which had clearly assigned the lower federal courts exclusive cognizance of admiralty proceedings. $I d$.

I agree that the second objection renders Marshall's disposition insupportable, on the view that Congress has authority to assign matters on the Court's original docket to the lower federal courts. Marshall, here, was resurrecting the strand of Marbury from which he had distanced himself in Cohens, a strand that the Court has clearly rejected. See supra notes 30-35 and accompanying text. I cannot join Gibbons' rejection of the claim that admiralty "cases" involving state parties were embraccd within the Court's original jurisdiction, however. Neither would Justice Johnson have agreed with Gibbons; he devoted much of his dissenting opinion to an attack on Marshall's claim that the Court's original jurisdiction over such a case could be deemed exclusive of lower federal court jurisdiction. See Madrazo, 26 U.S. (1 Pet.) at 124, 128-30.

370. Marshall's opinion also casts doubt on the view, expressed in Cohens, that matters within the Court's original jurisdiction might nonetheless appear as proper subjects of its appellate jurisdiction. See Madrazo, 26 U.S. (1 Pet.) at 124 (implying that the Court's original jurisdiction over state-party admiralty cases precluded district courts from entertaining them).

371. As Marshall observed, federal questions might "appear in the progress of a cause." Cohens v. Virginia, 19 U.S. (6 Wheat.) 264, 394 (1821). In Cohens itself, the federal question appeared by way of defense. See id. at 375 . Such cases, therefore, could not originate in the Supreme Court. Acceptance of Virginia's argument would thus defeat the judicial power by denying the Court appellate cognizance of claims that clearly presented federal questions but were of a type that could not arise originally in federal court. 
actions were original in character. ${ }^{372}$ In a more controversial and puzzling section of his opinion, Marshall seemed to contend that claims arising under the Constitution are not cognizable originally. His claim appears to rest on the view that the Constitution does not create any affirmative right of action against a state for relief from unconstitutional action. ${ }^{373}$

Marshall's rejection of affirmative constitutional claiuns against the states, or what we today call inplied rights of action, ${ }^{374}$ suffers from a curious anachronism. ${ }^{375}$ The ratification debates contain a host of direct and indirect assertions supporting the idea that the federal courts were responsible for assuring state compliance with the Constitution. ${ }^{376}$ Marshall hiunself gave voice to the remedial inperative that underlies such assertions in Osborn v. Bank of United States, ${ }^{377}$ taking great pains in that opinion to secure the existence of a federal docket for the assertion of original constitutional claims against the states ${ }^{378}$ and arguing that original federal juris-

372. See id. at $392-95$.

373. Marshall considers a hypothetical case involving a citizen who pays an unconstitutional export duty into the state's coffers. See id. at 402 . Marshall likens the citizen's assumpsit claim against the state for a return of the money to any other assumpsit raised by a mistaken payment; the state's refusal to comply with the assumpsit would not violate the Constitution and the case would not arise under the Constitution. Yet Marshall recognizes that the citizen could raise the Constitution as a bar to a state prosecution for refusal to pay the import duty and suggests that the Court could entertain such a federal defense on appeal. Id. at 402-04. For attempts to make sense of Marshall's puzzling reluctance to admit the existence of affirmative claims for constitutional violations, see Jackson, supra note 91, at 22 n.101, 76 n.310.

374. To be sure, the Court no longer regards the Constitution merely as a shield; its decision in $E x$ parte Young, 209 U.S. 123 (1908) (holding that a federal court may enjoin state officers from enforcing unconstitutional state laws), elearly transforms at least some limits on governmental power into affirmative claims for federal relief. On the origins of Young, and its significance in overcoming the bar of the Eleventh Amendment through the issuance of injunctive relief, see Fletcher, supra note 91, at 1088 n.222 (tracing to the early 1870 s the origins of the federal courts' authority to issue injunctions to state officers). On the implication of a federal claim for monetary relief arising from govemment officers' violation of constitutional limits on government action, see HART \& WECHSLER, supra note 10, at 917-35 (discussing Bivens v. Six Unknown Named Agents of Fed. Bureau of Narcotics, 403 U.S. 388 (1971)).

375. See Fletcher v. Peck, 10 U.S. (6 Cranch) 87,139 (1810) (suggesting that, before the adoption of the Eleventh Amendment, states were suable in federal court for their own violations of contracts under the Non-impairments Clause).

376. Arguments in support of the right of individuals to seek affirmative redress against the states appear in the statements of Hamilton, Madison, Wilson, Randolph, and St. George Tucker. See supra notes $184,187,346,188$.

377. 22 U.S. ( 9 Wheat.) 738 (1824).

378. We typically associate Marshall's decision in Osborn with its broad definition of the meaning of when a cause may arise under federal law for purposes of Article III. See infra note 379 . But the opinion also deserves notice for the way Marshall reshaped the law governing the availability of injunctive relief to uphold the power of the lower court to restrain Ohio's officials from retaiming the proceeds of their levy on the Bank. Marshall rejected two limitations on the power of common law courts to issue injunctions, one holding that injunctive relief was unavailable where remedies at law were adequate, the other denying the availability of mjunctive relief for claims involving the claimed destruction of a non-exclusive franchise. See Osborn, 22 U.S. (9 Wheat.) at 749-51. While Marshall does not in terms hold that the constitutional prohibition against the levy of the state tax itself gives rise to a claim against the executing officers, constitutional concerns plainly infiuenced Marshall's interpretation of injunctive relief. 
diction encompassed not only diverse party claims but also those causes in which a federal question forms an ingredient. ${ }^{379}$

Like many others, I am left somewhat perplexed by Marshall's decision in Cohens to announce a diverse-party reading of the Court's original jurisdiction. $^{380}$ One comes away from Cohens uncertain whether Marshall's account of original jurisdiction was a considered elaboration of Article III or an offhand basis for dismissing Virginia's challenge to the Court's appellate jurisdiction. To the extent the decision rests on Marshall's perception that federal courts could not exercise original cognizance of federal question claims, its rationale did not survive the subsequent decision in Osborn and the widespread agreement that actions may so originate today. It thus offers a singularly inappropriate rationale for continued adherence to Marshall's assessment of the scope of original jurisdiction at the time of the framing.

Professor Amar proposes to rehabihtate Marshall's dicta in Cohens by arguing that the diversity reading best comports with the "geographic logic" that underlies the allocation of original jurisdiction between the Supreme Court and other courts. According to Amar, the burden and expense of litigation at the nation's center explain why Article III limits the Court's original cognizance to disputes involving states or foreign envoys, whom the framers expected to enjoy easy access to a court at the seat of government, and bars Congress from broadening such jurisdiction. ${ }^{381}$ Amar contends that it is geographically more sensible to confer original jurisdiction on the Court in diverse-party disputes (to provide the parties a geographi-

\section{As Marshall explained,}

We think, then, that when a question to which the judicial power of the Union is extended by the constitution, forms an ingredient of the original cause, it is in the power of congress to give the circuit courts jurisdiction of that cause, although other questions of fact or law may be involved in it.

Osborn, 22 U.S. (9 Wheat.) at 823. See generally HART \& WECHSLER, supra note 10, at 967-89 (discussing and collecting cases regarding scope of constitutional grant of federal question jurisdiction); Paul J. Mishkin, The Federal "Question" in the District Courts, 53 Couum. L. Rev. 157 (1953) (providing a detailed account of the scope of federal question jurisdiction in the federal district courts and of the rationale underlying its establishment). It seems abundantly clear that this vision of federal jurisdiction departs rather dramatically from that espoused in Cohens, which suggested that common law actions with federal ingredients were grist for original state court consideration, subject to review on appcal. See Cohens v. Virginia, 19 U.S. (6 Wheat) 264, 418-20 (1821); cf. Osborn, 22 U.S. (9 Whcat.) at 884-89 (Johnson, J., dissenting) (arguing that the cause remained subject to state determination until such time as federal claims were asserted). Of course, Marshall treated Osborn as a case in which the state did not appear as a party on the record, but he later retraeted the broadest implications of that treatment in Governor of Georgia v. Madrazo, 26 U.S. (1 Pet.) 110, 122-24 (1828).

380. Cf. Currie, supra note 52, at $693 \& \mathrm{n} .290$ (noting that Marshall offered two arguments in response to Virginia's gloss on Marbury, where one would have sufficed; noting the inconsistency between Cohens and United States v. Texas).

A searching analysis of Marshall's opinion in Cohens appears in Jackson, supra note 91, at 22 n.101 (describing Marshall's "puzzling" view of the nature of Article III power over affirmative claims against the states and suggesting that he may have been influenced by the then current alloention of judicial power in the Judiciary Act of 1789).

381. See supra text accompanying note 44 . 
cally neutral tribunal) than in federal question disputes between a state and its own citizens, where both parties would bear the expense and inconvenience of litigation at the nation's political center.

Even if the underlying rationale behind the drafting of the Original Jurisdiction Clause had been geographic, however, a geographic account offers little support for a diversity reading of the Court's original jurisdiction. It is far from clear that the framers would have regarded. a federal question dispute involving, say, Virginia and its own citizens, as an inherently more inconvenient subject of original cognizance than, say, a diversity dispute between Georgia and a citizen of South Carolina. Furthermore, even if the framers had entertained such a conception of the relative convenience of the two heads of jurisdiction, Amar fails to explain why it would have entered into their calculus in defining the scope of the Court's original jurisdiction. Amar accepts the proposition that Congress has plenary control over diverse-party disputes on the Court's original docket and can shift matters to lower federal courts and even divest the federal system of such disputes entirely. On this assumption, it is hard to understand why convenience would have been a factor in the framers' defimition of the scope of the Court's original docket; after all, Congress could alleviate any inconvenience by assigning state-party disputes to the (more convenient) state and lower federal courts. ${ }^{382}$ Although I agree with Professor Amar that geographic considerations properly influence the distribution of federal judicial power, I do not believe that such considerations rehabilitate Marshall's fiawed diverse-party reading of the Original Jurisdiction Clause.

\section{$\mathrm{V}$}

\section{The Implications of Rethinking the Court's Original Jurisdiction}

My review of the historical context, text, drafting, and ratification reveals a relatively clear and consistent picture of the function of the Original Jurisdiction Clause. Sovereign immunity posed an important hurdle to implementing a central tenet of the framers' scheme-that states should be made to comply with supreme federal law. The law of nations generally barred an individual from suing a state in the courts of another sovereign-that, indeed, was the lesson of Nathan $v$. Virginia. ${ }^{383}$ The states, moreover, could hardly be expected to authorize the assertion of coercive claims against themselves in their own court systems. Actions against the states thus would evade the Supreme Court's appellate jurisdiction, in the absence of some assured original forum for their adjudication.

382. For Amar's view that Congress may divest the Court of its original jurisdiction over stateparty cases, see Amar, supra note 12, at 254 n.160; Amar, supra note 10, at 479-88. I have drawn the party alignments in the text's hypotheticals from Cohens v. Virginia, 19 U.S. (6 Wheat.) 264 (1821) and Chisholm v. Georgia, 2 U.S. (2 Dall.) 419 (1793).

383. 1 U.S. (1 Dall.) 77 (1781). For an account of the Nathan case, see supra notes 116-27 and accompanying text. 
Because the Madisomian compromise removed any assurance that there would be lower federal courts to provide an original forum, it drove the framers to assign original jurisdiction of claims against the states to the only federal court-the Supreme Court-that Congress was obliged to create.

The scope of the Court's original jurisdiction finds clear expression in Article III's reference to "all Cases" in which a state shall be a party. Literally read, the clause sweeps in cases arising under the Constitution, laws, and treaties of the United States, as well as those of admiralty and maritime jurisdiction. It thus operates to assure an original docket for cases in which persons test their own state's or another state's compliance with supreme federal law and for admiralty cases involving state parties. It also encompasses controversies in which states appear as parties, including disputes between the states themselves as well as those with the United States and citizens and subjects of other states and countries. The implications of these findings form the subject of the remainder of this Article.

\section{A. Sovereign Immunity: The Implications of Original Jurisdiction in Chisholm v. Georgia}

Although (as Hamilton said in a similar context) it represents something of a digression from the immediate subject at hand, ${ }^{384}$ this Section will briefly consider the insights that this study of the Court's original jurisdiction offers into the seemingly interminable debate over state sovereign immunity and the scope of the Eleventh Amendment. ${ }^{385}$ I do not wish to enter the lists as a full combatant; such entry would require adding even more pages to a piece that already challenges the patience of the most devoted readers. But I do wish to point out some of the most obvious and provocative implications of adopting this Article's interpretation of the words of the Original Jurisdiction Clause.

The language of Article III offers a relatively clear answer to the question of state suability. ${ }^{386}$ The framers viewed state compliance with the Constitution as too important to be left to the will of Congress and the states so they wrote state suability into Article III. States were subject to suit on the original docket of the Supreme Court in all federal question and admiralty "cases" as well as in all controversies in which the states appeared as parties (except where the opposing party was a citizen of the same state). This jurisdiction extended, as Hamilton, Madison, Randolph, and St. George Tucker affirmed, to cases arising under the Constitution ${ }^{387}$ and, as

384. For the text of Hamilton's digression, see supra note 302.

385. For the flavor of the Eleventh Amendment debates, see supra notes 4, 84, 91 and sources citcd therein.

386. The argument that the text of the Original Jurisdiction Clause essentially answers the question of state suability represents something of a break from traditional accounts, which emphasize the ambiguity of the constitutional plan. See supra note 98 .

387. See supra notes $184-85,187-88,332$ and accompanying text. 
Randolph and St. George Tucker affirmed, to cases in which states were sued by individuals. ${ }^{388}$

My interpretation of the text of Article III thus counters those who insist that states were to retain their law-of-nations immunity. The text does not so clearly address, however, the immunity that states enjoyed at common law. As to actions against the states in "cases" that implicate the Constitution, laws, and treaties of the United States, the Supremacy Clause trumps the common law immunity of the states. ${ }^{389}$ The question of common law immumity is more complex in "controversies," where the federal courts enjoy a judicial power that extends beyond the scope of federal supremacy. As to diversity claims against the states brought by individual suitors for money danages, federal law supplies no basis for overriding the common law's failure, as Hamilton put it, to create a right of action independent of the sovereign will. ${ }^{390}$

One finds much in Chisholm v. Georgia ${ }^{391}$ that confirms this understanding of Article III's ramifications for state sovereign immunity. In arguing on behalf of the plaintiff in support of the Court's jurisdiction, Randolph emphasized in the first paragraph of his argument that the Original Jurisdiction Clause literally encompassed claims brought by individuals against the states-an argument that all of the Justices appeared to accept without question. ${ }^{392}$ Randolph bolstered his argument for jurisdiction by noting the importance of securing an original forum in which individual suitors might obtain redress against the states for violations of supreme federal law. ${ }^{393}$ Although such a discussion had little bearing on

388. See supra notes 188,347 and accompanying text.

389. See supra note 102.

390. See supra notes 301-02. Many others have proposed a distinction between state immunity in federal question "cases" and that in diverse-party "controversies"; indeed, such a distinction lies at the heart of the diversity theory of the Eleventh Amendment. The formulation proposed in the text avoids repackaging the scope of state immunity into latter day Erie terms and thus escapes one of the difficulties that critics of the diversity theory have identified. See Marshall, supra note 4, at 1390-95 (noting the various problems inherent in analyzing Chisholm's effect on the Eleventh Amendment in Erie terms).

391. 2 U.S. (2 Dall.) 419 (1793).

392. See Chisholm, 2 U.S. (2 Dall.) at 420-21 (argument of Edmund Randolph) (emphasizing text of Article III's extension of judicial power to controversies between a state and the citizens of another state and the grant of original jurisdiction over cases in which a state shall be a party). Chief Justice Jay and Justice Blair both specifically referred to the Original Jurisdiction Clause in their opinions. Id. at 451 (Blair, J.); id. at 477 (Jay, C.J.).

The only Justice who can be said to have disagreed vehemently with Randolph's approach did not base his dissent on jurisdictional grounds. Rather, Justice Iredell emphasized Congress's failure to provide a mechanism for asserting the jurisdiction in question and expressed doubts as to whether the Constitution vested Congress with such a power, at least with respect to claims that failed to implicate federal law. See id. at 432-36, 449 (Iredell, J., dissenting) ("So far as states, under the Constitution, can be made legally liable to this authority, so far, to be sure, they are subordinate to the authority of the United States and their individual sovereignty is in this respect limited. But it is limited no further than the necessary execntion of such authority requires.").

393. Randolph eniphasized the necessity of original jurisdiction to ensure a forum for resolving claims brought by individuals to enforce federal rights against the states. See id. at 421-23. Randolph 
the scope of state suability in assumpsit actions of the kind before the Court, ${ }^{394}$ Justices Wilson and Cushing and Chief Justice Jay all agreed that the need for judicial remedies of state violations of federal law argued in favor of an affirmative answer to the jurisdictional question. ${ }^{395}$ That is, Randolph persuaded the Court of its jurisdiction over the case as well as of its power to issue process to the states in part by drawing the Court's attention to the need to hear actions brought by individual suitors in order to assure state compliance with federal law.

His success on the second question, whether an ordinary action of assunpsit that failed to implicate federal law would lie against the State of Georgia, was decidedly more mixed. Randolph himself was rather diffident, declining to argue the point at great length and suggesting that it would remain open following the state's appearance. ${ }^{396}$ Justice Iredell devoted his entire opinion to a rejection of the suability of states in such circuinstances, ${ }^{397}$ while both Chief Justice Jay and Justice Blair expressed their willingness to entertain further argument on the point. ${ }^{398}$ Thus, while four of the five Justices thought the Court had jurisdiction, only two (Justices Wilson and Cushing) clained that the existence of jurisdiction carried with it a federal judicial power to inpose monetary liability on the states outside the context of a dispute over federal law, and neither Justice devoted much attention to the point. ${ }^{399}$

cheerfully admitted that many forms of restraint upon the states could be effective without allowing affirmative claims against the states; he cited habeas corpus relief and constitutional defenses to the enforcement of state law as examples. Id. at 422. But Randolph went on to observe that such defensive remedies offer only partial protection. He then described a hypothetical suit brought to recover an estate that has been unconstitutionally confiscated and deposited in the state's treasury. For such action, only affirmative relief would redress the violation. Id.

394. No one doubted that the assumpsit action that Randolph was prosecuting against the State of Georgia failed to implicate federal law.

395. See Chisholm, 2 U.S. (2 Dall.) at 465 (Wilson, J.); id. at 469 (Cushing, J.); id. at $472-74$ (Jay, C.J.).

396. In contrast to the jurisdictional question, Randolph devoted comparatively little attention to the question whether assumpsit would lie. He acknowledged that "it does not follow, from a state being suable in some actions, that she is liable in every action." Id. at 428. But then he contended that the case of assumpsit was most free from cavil, essentially on the ground that a state, like an individual, was capable of making a promise. Id. He concluded by noting that the question would remain open for discussion "in almost every stage of the cause." Id.

397. See id. at 429-50.

398. See id. at $452-53$ (Blair, J.) (suggesting that he intended to decide only the question of jurisdiction and to leave open other questions pending the state's appearance); id. at 479 (Jay, C.J.) (stating that state suability need "not extend to all the demands, and to every kind of action").

399. Justice Wilson, for example, simply concluded without analysis "that the action lies." Id. at 466; see also id. at 469 (Cushing, J.) ("I think assumpsit will lie, if any suit; provided a state is capable of contracting.").

Though the Court did not expressly resolve the assumpsit question, it subsequently disposed of cases presenting such questions as if the states were plainly subject to suit. See GoEbel, supra note 234, at 736-37 (reporting that Oswald's assumpsit claim against New York went to trial on the merits, and resulted in a judgment in the plaintiff's favor, which New York subsequently paid). 
Everyone appears to agree that the Eleventh Amendment was passed in response to Chisholm. The framers of the Amendment evidently felt the Court was not to be trusted with jurisdiction over certain kinds of claims against the states and so wrote such jurisdiction out of Article III. Yet the text of the Amendment suggests that it offers a relatively technical gloss on Article III and not a wholesale prohibition against the assertion of jurisdiction over claims involving state defendants. Thus, it focuses on two disfavored classes of litigants-individual suitors who were citizens of either another state or country-and on suits and proceedings brought by such litigants in "law and equity." As many have observed, and in contrast to the Court's subsequent decisions in Hans v. Louisiana, ${ }^{400}$ Ex parte New York, ${ }^{401}$ and Monaco v. Mississippi, ${ }^{402}$ such techmical language appears to leave the judicial power intact in admiralty proceedings of all kinds and in suits at law and equity brought by plaintiffs other than those singled out for disfavored treatment.

I thus find myself much in agreement with the claims of revisionists who would overturn Hans and substitute a narrower construction of the Eleventh Amendment. ${ }^{403}$ I also agree with those who point out that a nar-

400. 134 U.S. 1 (1890).

401. 256 U.S. 490 (1921).

402. 292 U.S. 313 (1934).

403. For purposes of this analysis, we need not distinguish between the so-called diversity and literal explanations of the Eleventh Amendment; both would overrule Hans. It is worth noting, though, that my reading of Chisholm and the other historical materials does tend, to a modest degree, to support the literal account and to undermine the diversity explanation, at least insofar as the diversity account relies on a claim that no one would have perceived federal law claims as a potential source of liability in actions brought by the two disfavored litigants identified in the Eleventh Amendment. See Fletcher, supra note 3, at 1280-81. The diversity theory depends in part on the claim that Chisholm posed no clear threat of federal question liability and offered no basis for an amendment that would restrict the federal question heads of jurisdiction. As support for this assertion, diversity theorists observe that the Judiciary Act of 1789 failed to confer general origimal federal question jurisdiction on either the lower federal courts or on the Supreme Court. But this failure of the Act did not foreclose original actions against the states that rested on diversity jurisdiction and yet presented federal questions; indeed, the original cases on the Court's docket after Chisholm came down included at least one that implicated federal treaty rights. See GoEBEL, supra note 234, at 723-41. In the wake of Chisholm, such federal law claims may have appeared to pose a more significant financial threat to the states that supported the ratification of the Eleventh Amendment than an original diverse party claim that failed to implicate federal law. For Randolph's argument in favor of the assertion of jurisdiction in Chisholm had drawn a distinction between the enforcement of federal and non-federal rights against the states. While Randolph argued that the need to enforce federal rights against the states supported an assertion of jurisdiction, see supra note 393, he was less certain that a non-federal assumpsit claim of the kind asserted in Chisholm would lie against the states. Similarly, while a deeisive majority of the Court upheld the assertion of jurisdiction, only two of the four Justices in the majority clearly expressed the viev that an assumpsit action would lie. See supra note 399 . In other words, contemporary students of the opinions in Chisholm may have understood the Court to have expressed greater willinguess to fashion a damages remedy against the states in federal question than in common law claims. Such a view supports a literal reading of the Eleventh Amendment as cnrtailing all suits and proceedings initiated against the states by the disfavored parties, including those that implicate federal law. Rather than the inchoate threat portrayed by diversity theorists, federal claims (brought through party-based sources of jurisdiction) presented a clearer threat to state fiscs than non-federal claims. 
row construction of the Amendment's jurisdictional bar would not necessarily displace a variety of common law limitations on state suability. ${ }^{404}$ I find particularly apt Justice Stevens' view, announced in Pennsylvania v. Union Gas Co., that we really confront two different Eleventh Amendments-a textual Amendment that rather narrowly (but absolutely) limits the judicial power of the federal courts and a (broader) common law doctrine of immunity that remains subject to judicial and congressional management. ${ }^{405}$ As I have argued in niy review of the historical record, the framers of Article III niay well have understood states to enjoy both an (absolute) immunity fron suit in other courts under the law of nations and a qualified immunity fron suit under the common law. The framers' dual conception of state sovereign immunity hinks up nicely with the dual Eleventh Amendnent doctrine that Justice Stevens identifies in Union Gas.

Apart from its implications for the meaning of the Eleventh Amendment, this Article's account of state suability also suggests an inportant distinction between the suability of the United States and that of the several states. ${ }^{406}$ To be sure, the Constitution subjects the United States to the rule of law: the framers clearly anticipated that claims by the United States would go forward in federal court and that federal judges would test such claims against the Constitution. ${ }^{407}$ Moreover, the common law had authorized individuals to assert claims against governmental officers to test the legality of government action. ${ }^{408}$ It is not obvious, however, that Article III permits parties to bring affirmative claims against the United States without congressional authorization. ${ }^{409}$ Unlike its treatment of state-

404. See, e.g., Jackson, supra note 91, at 6-7.

405. See Pennsylvania v. Union Gas Co., 491 U.S. 1, $23-24$ (1989) (Stevens, J., concurring).

406. Before he joined the Court, Antonin Scalia suggested such a distinction, but claimed (incorrectly in my view) that the immunity of the states deserves greater protection than that of the United States. See Scalia, supra note 101, at 886 . In my view, the Original Jurisdiction Clause trumped state sovereign immunity under the law of nations, at least as to federal question claims, by requiring the Court to hear all state-party "cases." The failure of the clause to include cases in which the United States appears as a party, a choice the framers made deliberately, see supra notes $283-86$ and accompanying text, offers a strong textual basis for differential treatment.

407. See supra note 137.

408. See, e.g., United States v. Lee, 106 U.S. 196, 204 (1882) (permitting action brought against two federal officers to test title to Arlington National Cemetery; United States intervened to seek dismissal and filed writ of error). For a summary of actions against individual officers, sce HaRT \& WECHSLER, supra note 10, at 1114-17. In addition, common law writs of mandamus could be issued to compel government offieers to perform ministerial actions clearly required by law. Id. at 1092-95; see also David E. Engdahl, Immunity and Accountability for Positive Governmental Wrongs, 44 U. CoLo. L. REv. 1, 14-21 (1972) (discussing the rules of government officials' personal liability in the ninetcenth century).

409. The Court suggested in a number of early cases, albeit in dicta, that Article IIl does not authorize affirmative claims against the United States. See Cohens v. Virginia, 19 U.S. (6 Wheat.) 264, 411-12 (1821); Chisholm v. Georgia, 2 U.S. (2 Dall.) 419, 478 (1793) (Jay, C.J.). The leading casebook reports that the doctrine was applied for the first time in upholding a plea of immunity in 1846 . See HART \& WechSLER, supra note 10, at 1109 (citing United States v. McLemore, 45 U.S. (4 How.) 286 (1846)). Today, of course, Congress has established thorough schemes for the assertion of claims against the government in the Administrative Procedure Act, 5 U.S.C. $\$ \S 701-06$ (1988), the Tucker 
party cases, the Original Jurisdiction Clause does not mandate original federal cognizance of cases in which the United States shall be a party; ${ }^{410}$ indeed, the framers deliberately struck such a grant from Article III. As a result, no federal court enjoys a constitutionally mandated grant of original jurisdiction by virtue of the presence of the United States as a party. The absence of such a mandatory original forun for federal question claims means that Congress retains legislative discretion to decide whether to authorize suits against the United States by establishing some original tribunal to hear such claims.

Finally, this Article suggests that the doctrine of sovereign immunity offers a cogent explanation for the final contours of the Original Jurisdiction Clause-contours that have vexed many distinguished observers. ${ }^{411}$ The framers overrode states' sovereign immunity under the law of nations when they included state-party "cases" in an effort to assure the existence of an original federal docket for federal question claims against the states. ${ }^{412}$ Claims involving foreign nations were omitted from the Court's original cognizance, both because federal law imposed no directly enforceable obligations on such nations and because a mandatory source of original jurisdiction was inconsistent with such nations' undoubted immunity under international law. ${ }^{413}$ Finally, U.S.-party "cases" were omitted not because the Constitution did not bind the federal government, but because the framers made a deliberate decision to leave the scope of the federal government's immunity from suit in the hands of Congress. ${ }^{414}$

Act, 28 U.S.C. $\S \S 1346(a)(2), 1491$ (a)(1) (1988) and Federal Tort Claims Act, 28 U.S.C. $\S \S 1346(b)$, 1402, 2401-02, 2412 (1988). See generally JoHN M. STEAdMAN Et AL., LmGATION WITH THE FedERAL GOVERNMENT (2d ed. 1983) (canvassing the gamut of relevant statutes governing litigation with the United States).

410. As the discussion of the work of the Philadelphia Convention on August 27 makes clear, moreover, the framers' decision to omit the United States from the clause was carefully considered. See supra notes 283-86 and accompanying text.

411. Compare HART \& WECHSLER, supra note 10, at 386-87 (posing the question why "the drafters of Article III single[d] out [ambassador and state-party cases] for mandatory treatment and le[ft] Congress an option in cases in which the United States was a party") with Amar, supra note 12, at 1524 (suggesting that this is a "hard question" to which "[t]here are many possible answers").

412. See supra notes $102-27$ and accompanying text.

413. See supra notes $234-38$ and accompanying text.

414. On the importance of the omission of a mandatory source of federal jurisdiction over claims involving the United States, see Martin v. Hunter's Lessee, 14 U.S. (1 Wheat.) 304, 335-36 (1816) (noting that an imperative grant of jurisdiction in controversies involving the United States might have becn taken to override sovereign immunity). Note that the failure of the framers to confer original jurisdiction on the Supreme Court in U.S.-party cases did not subject the United States to suits in the state trial courts. The United States was understood to rctain its "foreign" immurity from such suits in keeping with the law of nations and its general sovereignty; such an understanding underlies Randolph's explanation as to why the federal courts would enjoy exclusive jurisdiction over claims against the United States. See 4 Documentary History of THE SUPREME Court, supra note 41, at 130 (remarks of Edmund Randolph) ("If the United States, as far as they can be a party defendant, should happen to be so, their own courts can alone judge them. To drag a confederacy before the courts of one of its members, would reverse the plain dictates of order, hazard the most critical interests of the Umion upon 


\section{B. Rethinking the Purpose of Original Jurisdiction}

As we have seen, the Original Jurisdiction Clause reflects both the framers' commitment to the right of assertion of coercive federal claims against the states and their recognition that such clainıs require an original federal docket. But the framers did not oppose the assignment of original niatters to the lower federal courts. Indeed, the Assignment Clause would have authorized Congress to assign all original matters to the lower federal courts. The ultiniate deletion of the clause on grounds of redundancy did not blunt its intended effect; the deletion siniply reflected the framers' presuniption that Congress' power of assignment was included in its power to ordain and establish lower federal courts and to nake all laws necessary and proper for the conduct of federal judicial business. ${ }^{415}$

We should therefore abandon the "dignified tribunal" account of the Court's original docket to the extent the account posits that the lower federal courts would be unable to deal justly with clainis involving the states. We have, after all, proceeded for two hundred years on the assumption that lower federal courts nuay entertain actions that fall within the Court's original grant. ${ }^{416}$ Federal courts, noreover, have long asserted federal question jurisdiction over clainis brought by state plaintiffs. Relying on Ex parte Young, ${ }^{417}$ the lower federal courts have long exercised general federal question jurisdiction over actions to enjoin state officers from violating constitutional limits on state authority. ${ }^{418}$ The dignified tribunal account presents an unnecessarily restrictive view of the power of Congress to give the lower federal courts cognizance of original matters involving the states.

Despite niy rejection of the dignified tribunal account and its suggestion that the Court owes the states a place on its original docket, the state's argument in Louisiana v. Cummins has sonie force. ${ }^{419}$ Currently, only the Suprenie Court niay exercise diversity jurisdiction over actions brought by states. $^{420}$ No statute grants the lower federal courts jurisdiction over diversity suits involving state parties. ${ }^{421}$ The decision of the Court in cases such as Cummins to refrain from hearing original claims thus requires state plaintiffs to bring suit in state court and denies state parties the same access to a federal forum that other litigants currently enjoy. It is this quirk of

the pleasure of a single state; and enable every individual state under the pretext of a forensic sentence, to arrogate the general sovereignty.").

415. See supra notes $260-62$ and accompanying text.

416. See supra notes $24-35$ and accompanying text.

417. 209 U.S. 123 (1908).

418. On the importance of the Young fiction, see Erwin Chemerinsky, Federal Jurisdiction 344-48 (1989).

419. For a summary of the argument by Louisiana's attomey general against the Court's decision to decline jurisdiction, see supra note 40 and accompanying text.

420. For the constitutional definition of the Court's original jurisdiction, see supra note 176 and accompanying text; for the statutory delineation, see supra note 351 and accompanying text.

421. See 28 U.S.C. \$ 1332(a) (1988), supra note 69 . There is no provision for disputes involving the states themselves. 
federal jurisdiction that Louisiana's attorney general criticized as transforming the benefit of original cognizance into a burden. ${ }^{422}$

The answer to Louisiana's complaint, I submit, does not lie in abandoning the Court's discretionary control over its original docket. Rather, we should abandon the dignified tribunal account's limits on the power of the lower federal courts to entertain diverse-party claims involving state parties. As we've already seen, the dignified tribunal account does not present a convincing argument against the assignment of original jurisdiction to the lower federal courts. Decisions upholding the power of Congress to effect such assignments rest in good measure on the need to provide parties with a convenient alternative to the Supreme Court's original docket. ${ }^{423}$ We need to build on these decisions, free from the rhetoric of the "dignified tribunal" argument, and rethink the proper allocation of the judiciary's business between the original dockets of the supreme and inferior courts. I offer some preliminary suggestions in the next Section.

\section{Rethinking the Scope and Allocation of the Court's Original Jurisdiction}

This Article suggests that the grant of original jurisdiction over stateparty cases embraces federal question claims involving state parties, as well as those of admiralty and inaritime jurisdiction. I therefore suggest that Congress should broaden its description of the Court's original jurisdiction to encompass all of the matters that the framers assigned to the Court's original docket. Sucl a statute need not, however, maintain its current commitment to exclusive adjudication of state-party matters on the Court's original docket. It might simply provide that:

The Supreme Court shall have original, but nonexclusive, jurisdiction

(1) in all cases arising under the Constitution, laws, and treaties of the Umited States;

(2) in all cases of admiralty and maritime jurisdiction; and

(3) in all controversies

in which a state shall be a party. ${ }^{424}$

Such a statute would effectuate the overarching purpose of assuring the availability of the Court's original docket for all matters involving state parties without unduly interfering with inferior tribunals' assertion of jurisdiction over such matters. The Court would retain discretionary control over its original docket and, with it, the authority to remit the parties to another tribunal for the resolution of state-party claims. Presumably, it

422. See supra note 40 and accompanying text.

423. See, e.g., Ames v. Kansas, 111 U.S. 449, 464 (1884); Börs v. Preston, 111 U.S. 252, 260 (1884).

424. Such a statutory grant would, of course, remain subject to the limitations of the Eleventh Amendment. 
would continue to remit states' federal law claims against individual defendants to the lower federal courts, which would entertain such claims under their grant of general federal question jurisdiction. ${ }^{425}$

- My proposed statute would not adversely affect the Court's management of its original docket. The Court would retain original jurisdiction over claims brought by the United States against the states, as well as that over claims between the states themselves. Presumably, boundary and water rights disputes, both of which present federal questions, would continue to represent the major component of the Court's original workload. In addition, the Court would have jurisdiction over claims brought by states to enjoin the United States from taking action that interferes with the states' constitutional prerogatives. It could thus hear cases such as South Carolina v. Regan ${ }^{426}$ without relying on diversity between the state and a United States government official as the jurisdictional predicate.

The extension of general federal question jurisdiction over all cases involving state parties would also authorize, but not require, the Court to hear coercive actions brought in the first instance against the states thentselves. The Eleventh Amendment would remain as a barrier to the assertion of many such claims, whether they were brought on the Court's original docket or on that of the lower federal courts. Presumably, the Court would simply refuse to hear such clainis in the great majority of instances, either by citing the Eleventh Amendnent directly or, in the event of a revision of Eleventh Amendnent doctrine, by declining to exercise its jurisdiction. The proposed statute would effect little change in the Court's original diet but it would more closely link the jurisdictional basis for the Court's cases to the federal question nature of nost of the original claims that it resolves on the merits.

The proposed change thus does not threaten to swainp the Court with original actions or to burden the Court with substantially more original disputes. Parties who wish to bring such clainis must seek leave to file, ${ }^{427}$ and relatively straightforward rules govern the Court's willingness to exercise its discretion to hear such claims. The original docket need not burden the Court any more than its discretionary appellate docket. The Court would still retain the discretion to decide not to hear a case against a state. The broadened reach of the original docket would, however, eliminate the partyalignment wrinkle as a limit on the Court's original jurisdiction and thus provide the Court with a broader array of important federal question cases from which to choose.

Two inportant changes in the jurisdiction of the lower federal courts also deserve consideration. First, Congress should provide the lower federal courts with concurrent jurisdiction over claims brought by states

425. See supra notes $66-68$ and accompanying text.

426. 465 U.S. 367 (1984).

427. See supra note 36 . 
against the citizens of other states and countries. This would offer the states a convenient federal forum in which to litigate claims that depend entirely on diversity and which today are rarely disposed of on the merits by the Supreme Court. This proposal would satisfy, in good measure, the objections of the attorney general in Louisiana v. Cummins.

Second, Congress should consider providing the lower federal courts with concurrent jurisdiction over certain kinds of controversies between two or more states. Many such controversies rest largely on state law, notably those in the nature of interpleader that grow out of disputes between the states over rights of escheat and the imposition of taxes on decedents' estates. ${ }^{428}$ States understandably do not wish to submit such disputes to the state courts and can make a legitimate claim for the necessity of an impartial federal forum. Under the current jurisdictional framework, however, the Supreme Court enjoys exclusive jurisdiction over all controversies between two or more states, whether they rest essentially on state or federal law. By broadening the lower courts' jurisdiction to encompass interstate controversies, Congress could free the Court from the necessity of originally hearing claims, such as those over rights of taxation and escheat, that appear to merit federal attention solely to secure a binding resolution.

Extending lower federal court jurisdiction to interstate disputes may prove more controversial than extending it to actions brought by states against individuals. Venued in the District of Columbia, outside the territory of any particular state, the Court's original docket offers the states a neutral forum for the resolution of their disputes that most lower federal courts, as presently structured, do not offer. ${ }^{429}$ States might oppose a statute that called upon them to submit their disputes to a federal judge who sits in and was appointed from the bar of one of the two contending states. Of course, such federal judges would enjoy structural guarantees of impartiality-life tenure and salary protection-and these considerations might obviate any lingering state objections to the submission of their disputes with other states to an inferior federal tribunal. If not, Congress could respond with a special provision assigning jurisdiction of interstate disputes to the United States District Court for the District of Columbia-a court that sits outside the territorial boundaries of contending states. ${ }^{430}$ In any case, appellate review in the Supreme Court would remain available.

428. See, e.g., California v. Texas, 457 U.S. 164 (1982); Texas v. Florida, 306 U.S. 398 (1939).

429. On the geographical neutrality of the Court's original docket, see supra notes $45-48$ and accompanying text.

430. Such a venue provision would offer a geographically neutral forum in which to litigate the dispute and would opcrate somewhat like the Court's current practice of assigning interstate disputes to a special master. On the use of masters, see Benjamin G. Cohen, Wading Through the Procedural Marshes of Original Jurisdiction Guided by the Tidelands Cases: A Trial Before the United States Supreme Court, 11 AM. J. TRIAL Advoc. 65, 73-76 (1987). Masters come from many sources, including the ranks of retired Article III judges. See id. 


\section{CONCLUSION}

In the management of its appellate docket, the Supreme Court draws an important distinction between questions of federal and state law. Although it enjoys jurisdiction to review final state court decisions that present federal questions, it has never claimed, nor been given, the power to review such state court decisions in state law matters, even where the alignment of the parties presents a "controversy" to which federal judicial power extends. The Court does enjoy the theoretical power to review determinations of state law by the lower federal courts sitting in diversity. But in the wake of Erie, the Court rarely hears such state law matters, choosing understandably to devote its appellate resources to the resolution of important questions of federal law. In tandem, these limitations on its appellate jurisdiction and its own exercise of discretion in choosing cases for appellate resolution reflect a widely shared perception that the Court should focus its resources on assuring the effective and uniform interpretation of federal law.

The Court's management of its original docket reflects many of the same concerns, as Justice Harlan's opimion in Ohio v. Wyandotte Chemicals Corp. makes clear. Yet the relevant jurisdictional statutes fail to confer power on the Court to hear federal question disputes involving state parties. Instead, the jurisdictional statutes limit the Court's original jurisdiction to disputes between diverse contending parties-precisely the kind of diversity disputes that otherwise lie within the lower federal courts' diversity jurisdiction and that the Court rarely agrees to hear on appeal. Compounding the curious allocation of judicial power, moreover, the jurisdictional statutes give the lower federal courts cognizance of federal question claims (including those instituted by state plaintiffs) and deny the lower federal courts jurisdiction of state law claims instituted by state plaintiffs, even those against diverse defendants.

Nothing in the text or history of the Original Jurisdiction Clause requires the maintenance of this odd allocation of federal judicial resources. The text and history suggest, by contrast, that the Clause was designed primarily to assure the existence of an original docket to hear coercive federal claims against the states. The Court's original docket thus encompasses not only the state-party "controversies" that involve diverse contending parties but also the federal question and admiralty claims literally embraced in its reference to "cases" in which a state shall be a party. The Clause was not, however, intended to deprive Congress of the power to assign such disputes concurrently to the lower federal courts for original resolution.

Congress should thus formulate a jurisdictional statute that provides for an allocation of the Court's judicial power in cases of original cognizance that more closely resembles the allocation of the Court's appellate resources. By enacting a statute that confers original jurisdiction on the Court in federal question cases in which a state is a party, Congress would 
signal its recognition that the Court properly focuses its attention on federal questions. By similarly broadening the lower federal courts' jurisdiction to enconipass some state-party controversies, Congress could offer states access to a federal forum in diversity disputes over state law without burdening the Court with their resolution. Such changes would not impose an undue burden on the Court; its discretion to decline jurisdiction would remain in place. When the dust settled, the Court would enjoy discretionary control of an original docket that, like its appellate docket, would emphasize the resolution of federal questions. 


$$
\text { , }
$$




\section{California Law Review}

VoL. 82

MAY 1994

No. 3

Copyright ( 1994 by California Law Review, Inc.

\section{BOARD OF EDITORS}

1993-94

\author{
Editor-in-Chief \\ Anut R. Desai \\ Managing Editor \\ Vivian B. Distler
}

Senior Articles Editor

Thomas J. Peckham

Articles Editors

Nancy Combs

DaN S. SOKOLOV

PhiLIP C. Tencer

GeORGE L. WASHINGTON, JR.

Book Review Editor James M. Aquilina

JefF CARLisle

L. JAY KUO

Matt LevetT

JENNIFER OCHS

Fabio Arcila JR.

ERIK BABCOCK

SYLVIA L. BRADDOM

ERIC DOBMEIER

ROGER DOUGHTY

EDWARD L. Adams

ANDREW M. Agtagma

KRISTIN AMERIING

ABRIL R. BEDARF

BRETT E. COOPER

Melissa A. Dawson

Douglas K. Dorst

JeNNIFer L. Gillum

JOHN HOU

JosepH E. JARAMILLO

MICHAEL S. JOAQUIN

JESSICA M. KARNER

LISA M. KERR
Senior Executive Editor

NICOLE M. RYAN

Executive Editors

Steve Geary

TODD NOONAN

Cathy J. Ostiller

Production Editor

JAN E. TOMSKY

Associate Editors

RICK E. RAYL

FRANK SOLOMON

RUSSELL SOMMERS

Members

TRACY FrIEDMAN

David E. GoldsteIn

ANDREW HACKBERT

Craig Norris

David KIng

MrCheLLe M. LeMLEY

Chun Pok Leung

ELIZABETH J. LEVENSOHN

Michael D. Lewis

ALICE K. MA

StUART J. MACKeY

KERNE MATSUBARA

JEFFREY L. MENGOLI

BURKE F. NORTON

Thu Trám T. Phi

Peter W. Poulos

Office Manager

KAREN E. FAsS
Senior Notes \& Comments Editor

Frank Cialone

Notes \& Comments Editors

JAMES KNOX

Flavio Rose

SARAH C. WiLSON

Research \& Topics Editor

Beatrice B. NGuYen

Molly S. Stump

Christine H. SuH

MARSha TODD

BRIAN M. TORRES

Daniel Pines

Ellen J. Rubin

DAVID W. Simon

Kathryn E. Suarez

TIMOTHY J. WALSH

Stephanie Powers-SkafF

Maria Victoria Recalde-

BERNSTEIN

Chris RILEY

MATtHEW F. Roberts

SEAN RODGERS

Kulpreet Singh

AISHAH SMITH

Nancy A. Solotkin

SCOTT N. TACHIKI

SUSIE TER JUNG

ERIC H. WANG

TUNG YIN 
,

$$
\text { , }
$$

